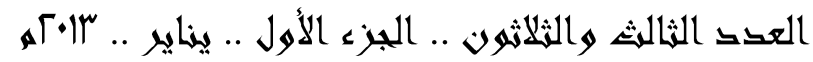

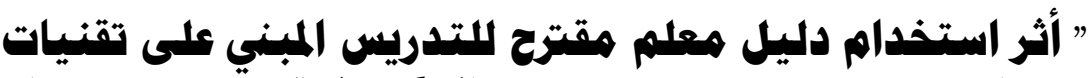

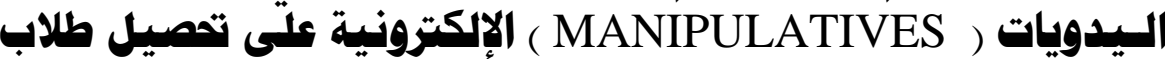 الصف الثالث المتوسط في مادة الرئروية عليات "
}

د / طافربن احمل مصلح القرني

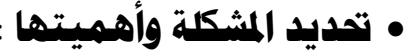

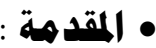

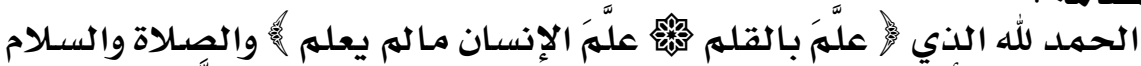

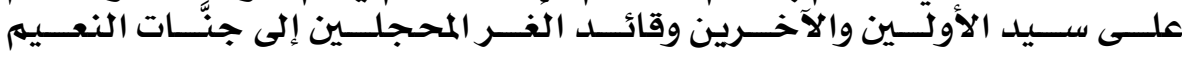

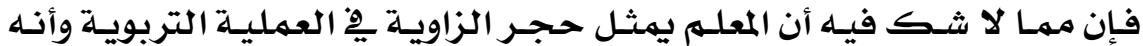

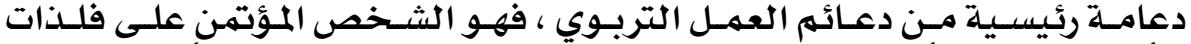

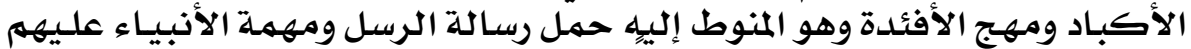

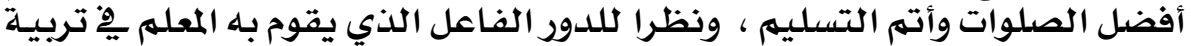

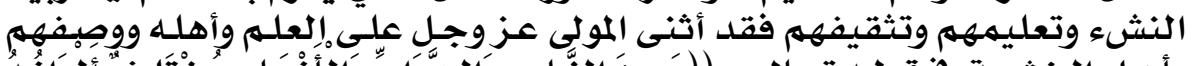

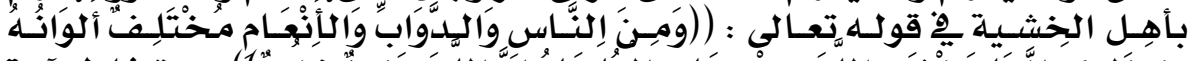

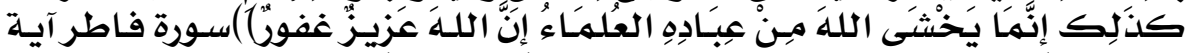

ومما لاشك فيه أن الرياضيات هي إحلدى المجالات المعرفية المتميزة التي لها لها

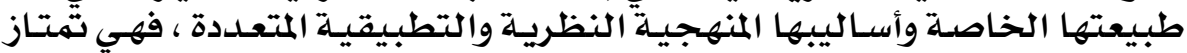

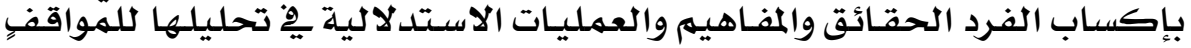

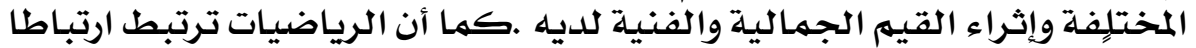

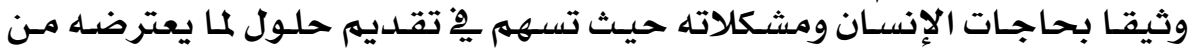

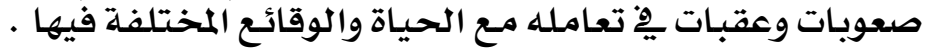

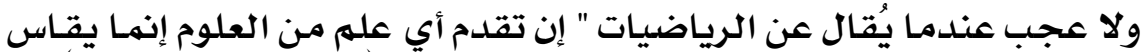

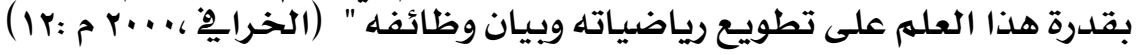

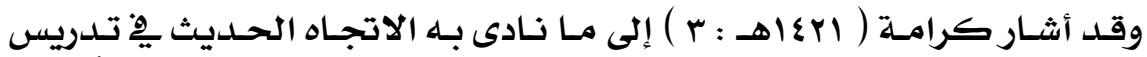

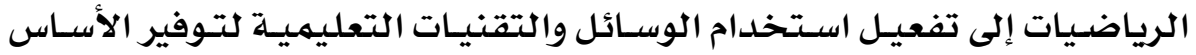

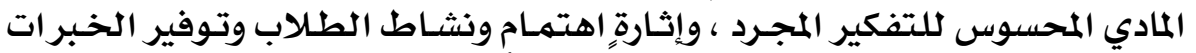
الواقعية ، والقدرة على الاكتشاف بلدئ المار من الأشياء المحسوسة.

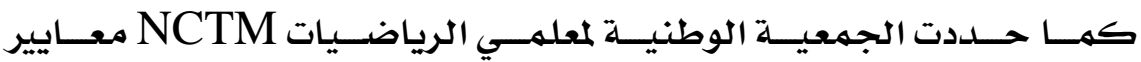

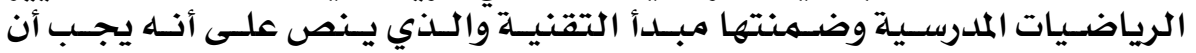

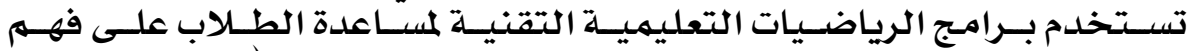

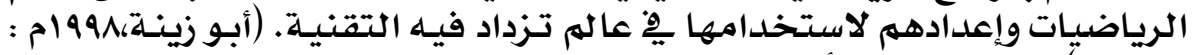

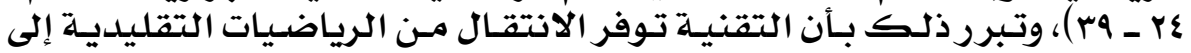

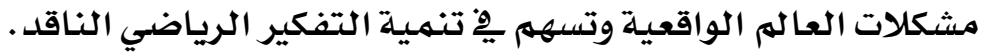

\section{$10 \mathrm{~V}$}

دوأهائت كربية في الثتبية وعثم النفشي (ASEP) 


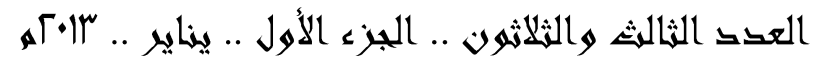

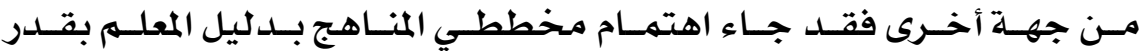

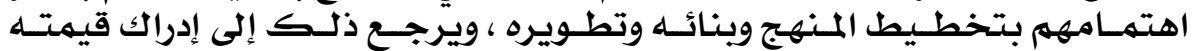

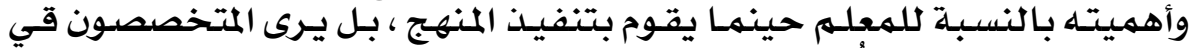

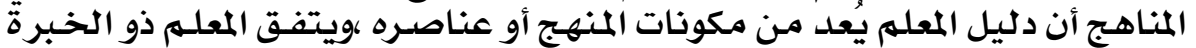

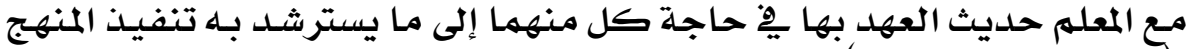

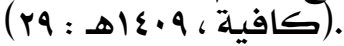

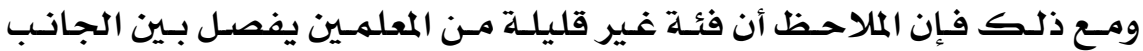

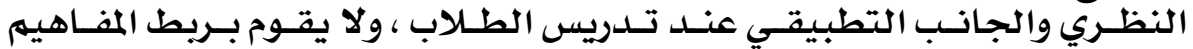

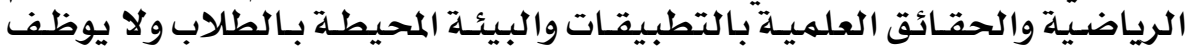

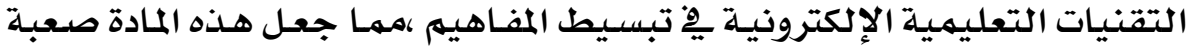

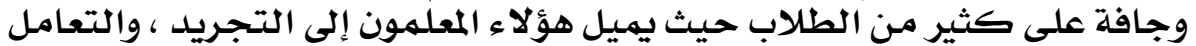

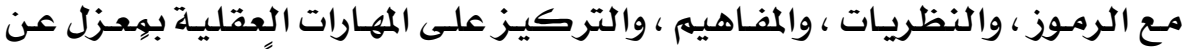

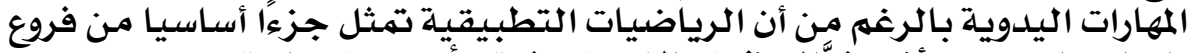

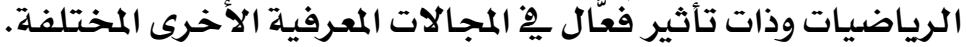

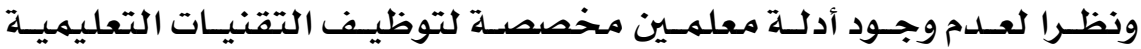

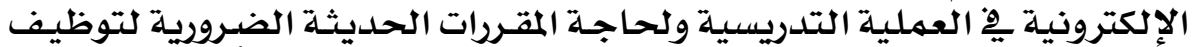

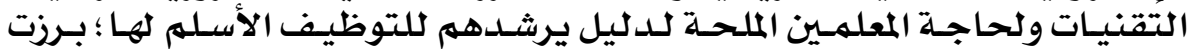

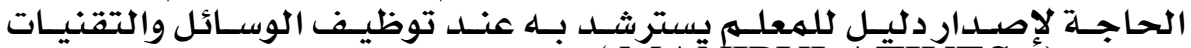

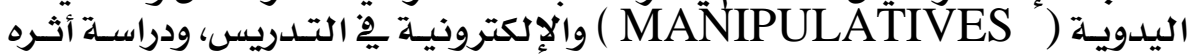

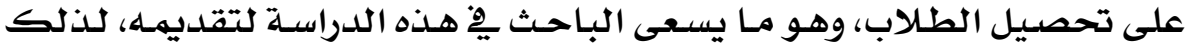

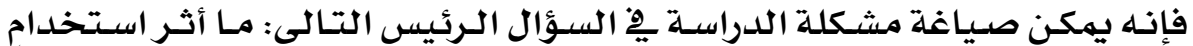

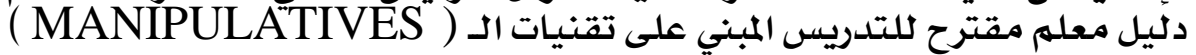

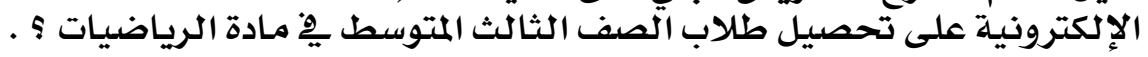

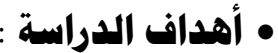

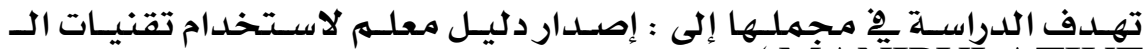

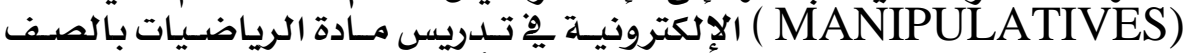

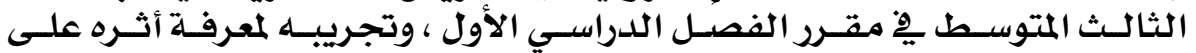
تحصيل الطلاب.

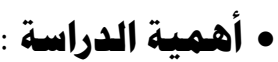
تلخص أهمية الدراسة : ألدراسة فيما يلي :

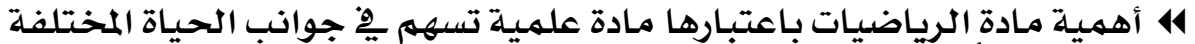

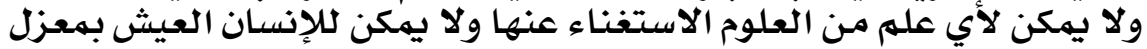

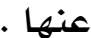

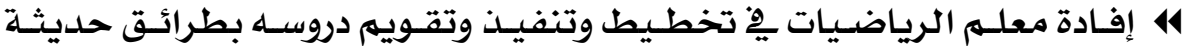

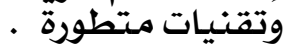

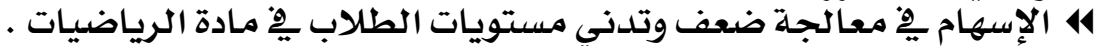

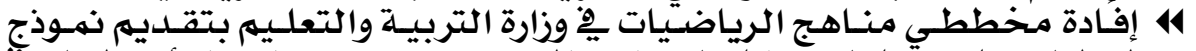

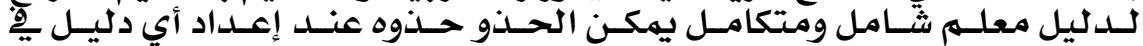

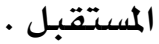

\section{$10 \wedge$}




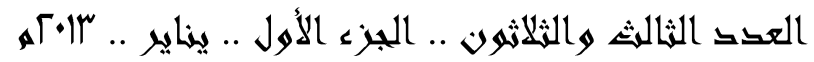

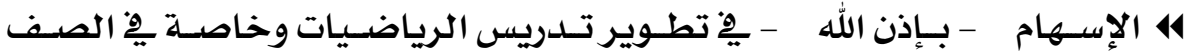

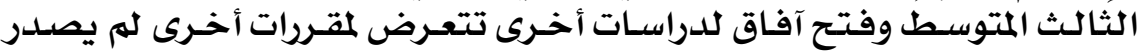

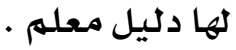

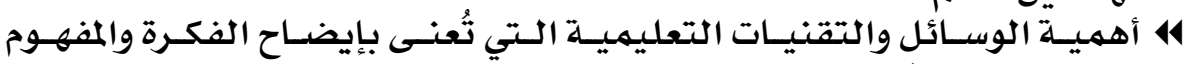

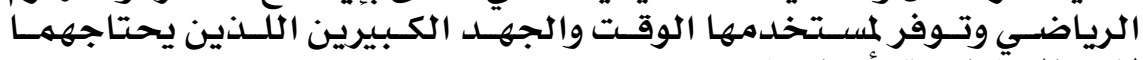

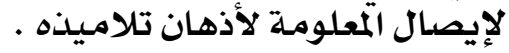

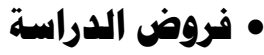
تهوف الدراسة للتحقق من صحة الفروض الفروض التالية:

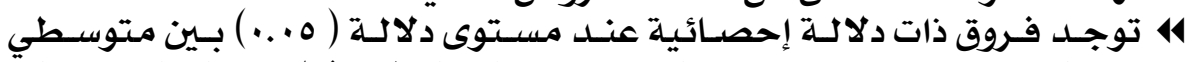

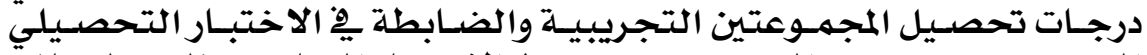

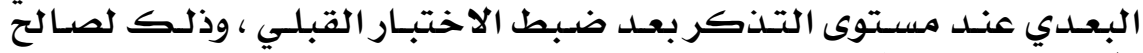

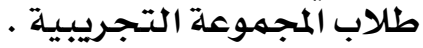

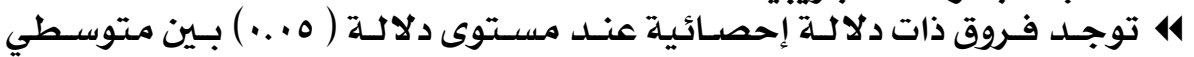

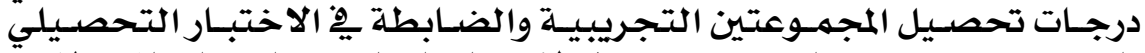

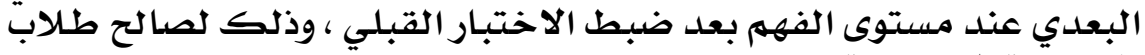

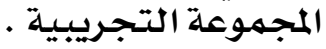

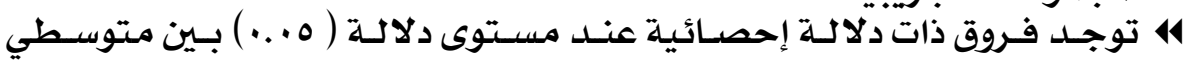

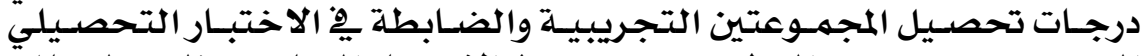

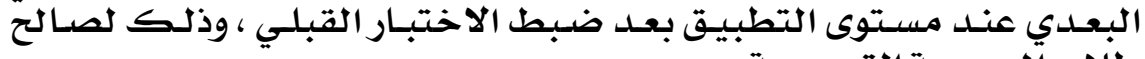

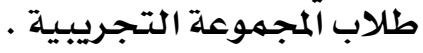

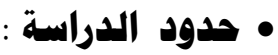

تقتصر حدود الدراسة على المحددات التالية : 4 الموضوعي : مقرر الرياضيات للصف الثرالث المتوسط يِّ الفصل الدراسي الأول

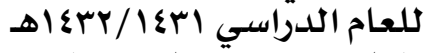

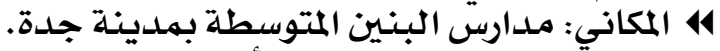

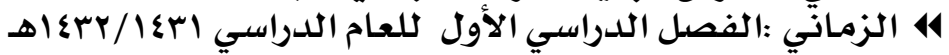

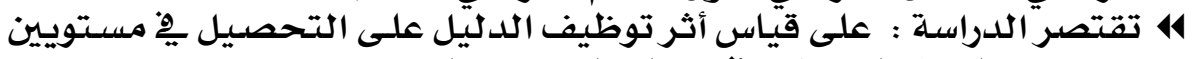

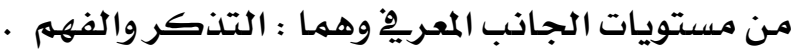

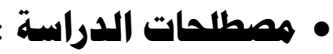

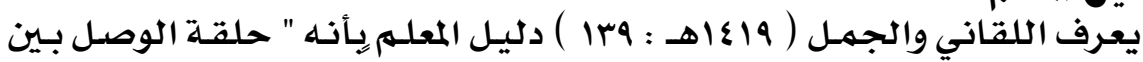

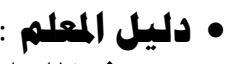

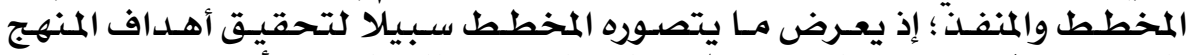

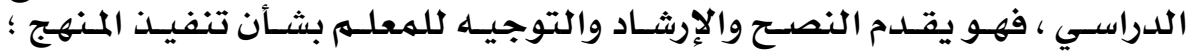

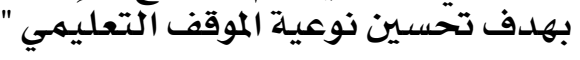

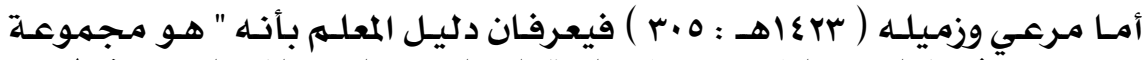

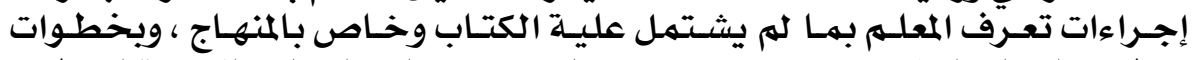

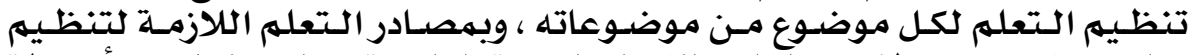
تعلهم كل موضوع لا سيما الوسائل التعليمية العلمية ، والخرائط ، والأنشطة

\section{9}

دوأهائت كربية في الثتبية وعثم النفشي (ASEP) 


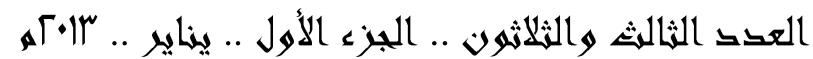

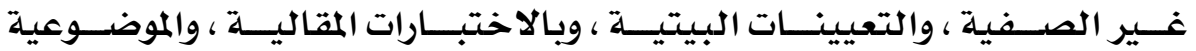

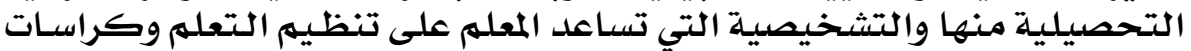

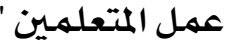

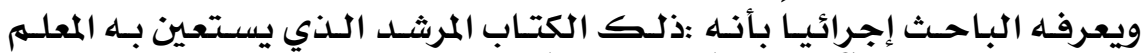

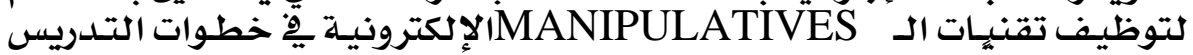
المختلفة سعيا للوصول لبيئة صفية فاعلة.

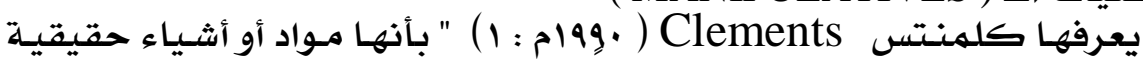

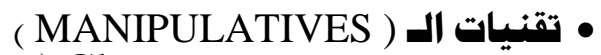

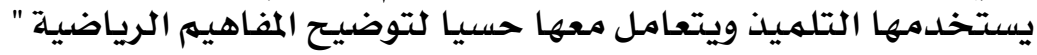

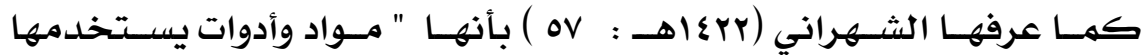

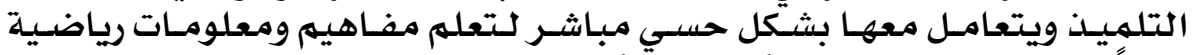

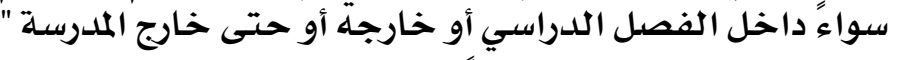

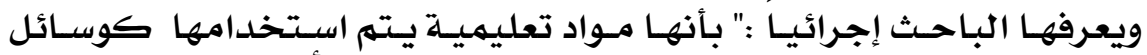

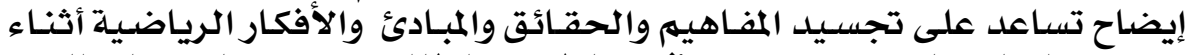

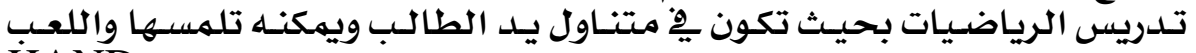

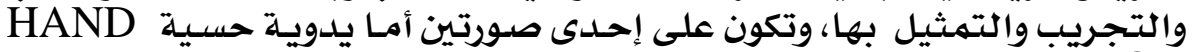

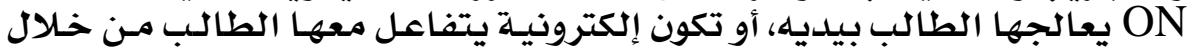

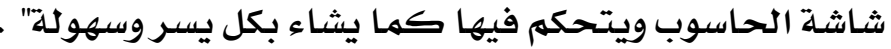

\section{• • الإطار النظري والدراسات السابقة :}

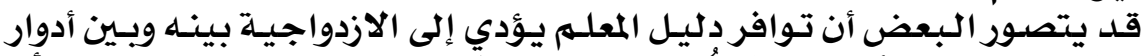

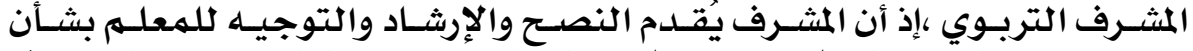

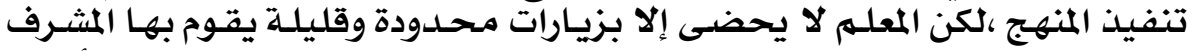

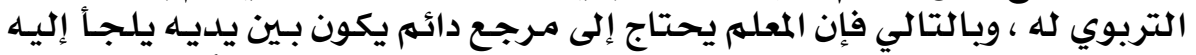

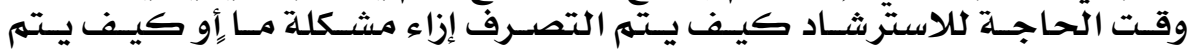

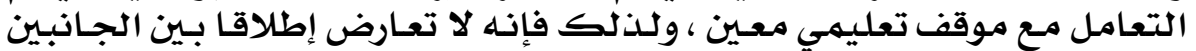

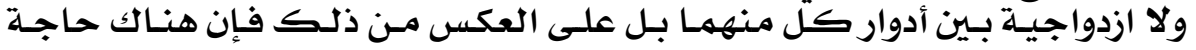

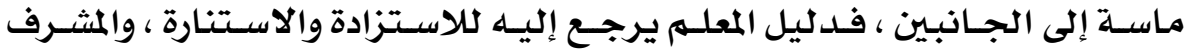

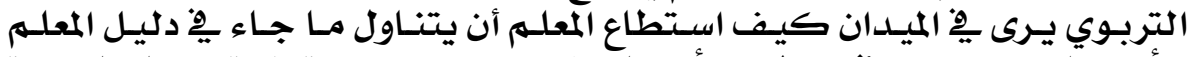

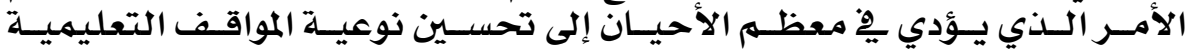

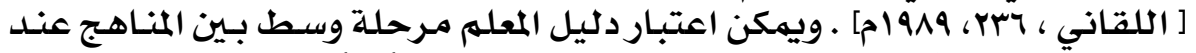

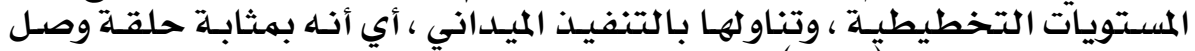

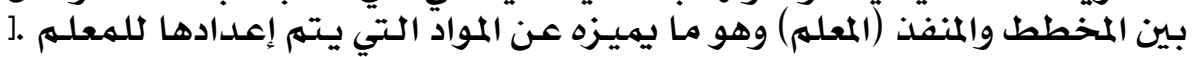

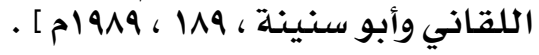

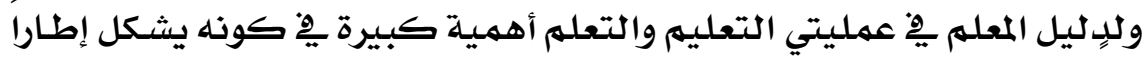

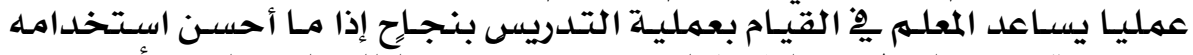
ومن جهة يمكن القول إن دليل المعلم يعد مفيدا ومهما للمعلم وذلك لأن النه :

\section{7.}




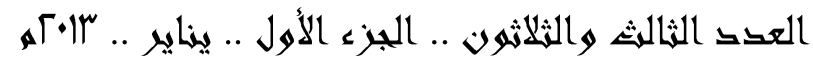

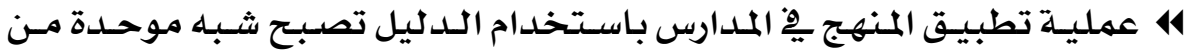

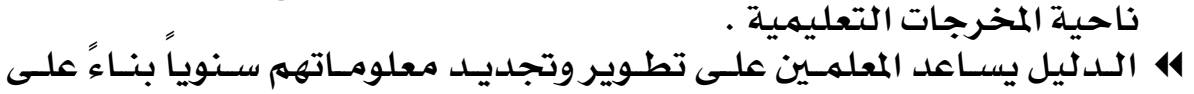

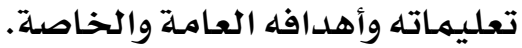

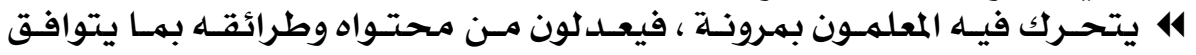

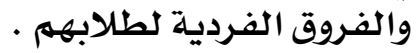

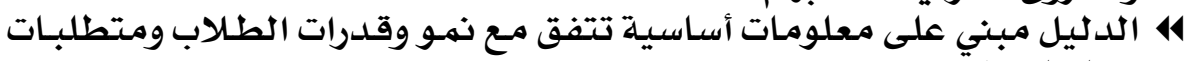

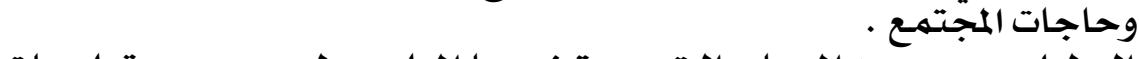

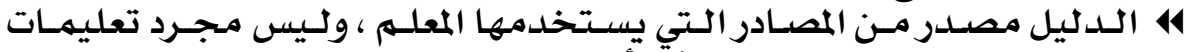

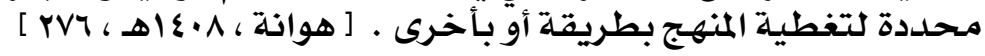

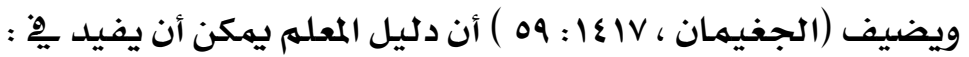

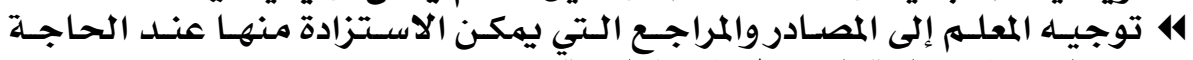

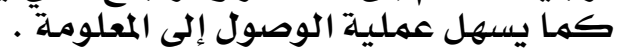

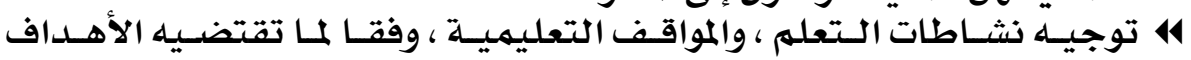

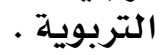

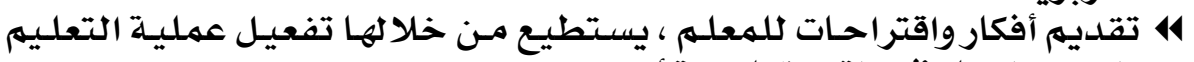

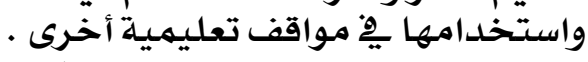

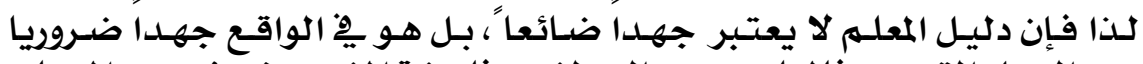

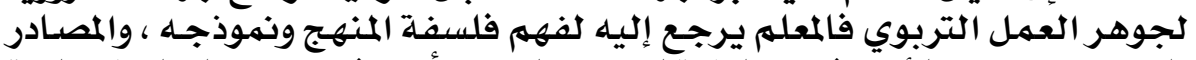

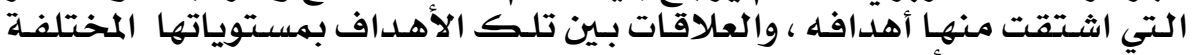

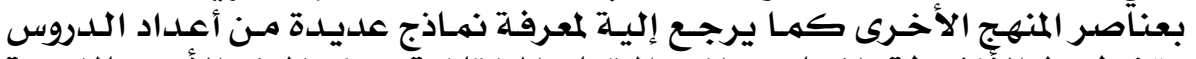

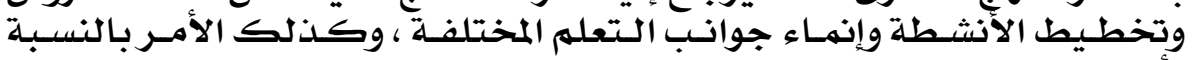

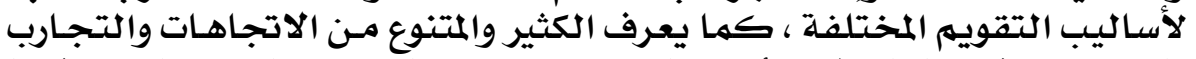

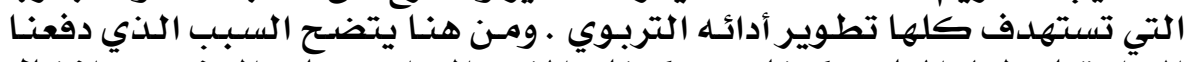

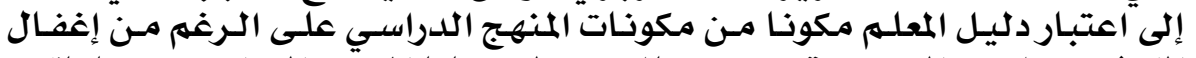

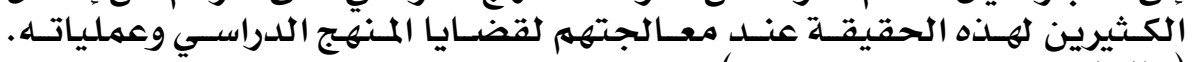

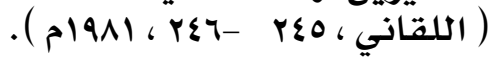

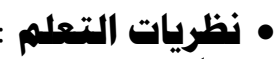

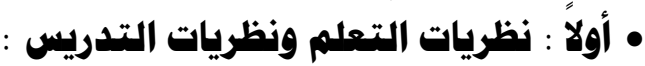

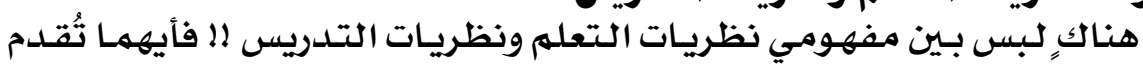

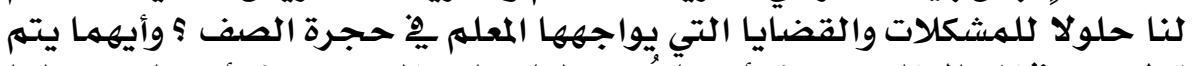

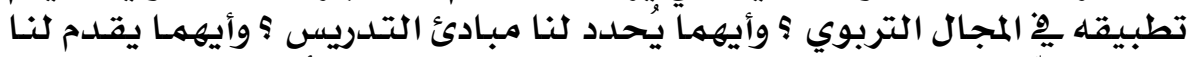

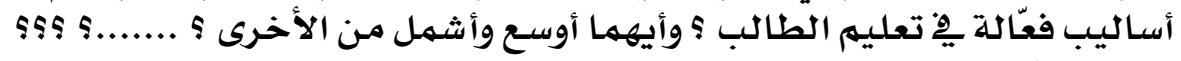

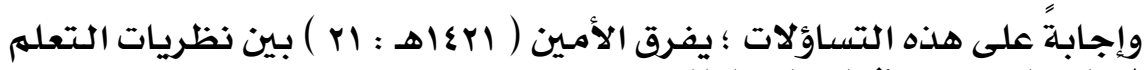

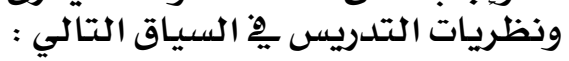

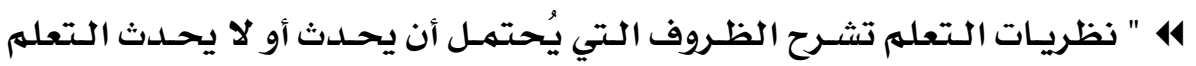

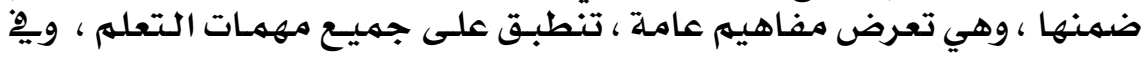

\section{1}




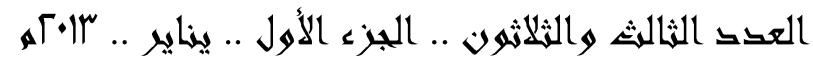

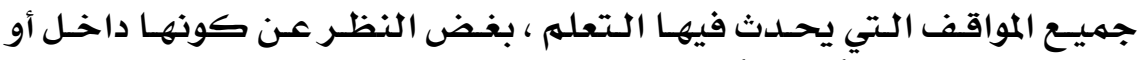

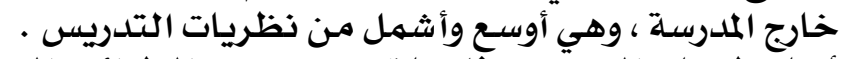

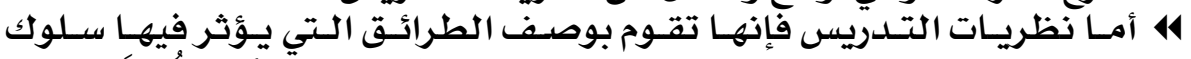

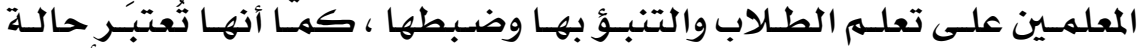

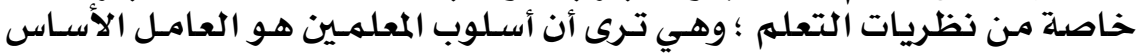

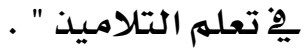

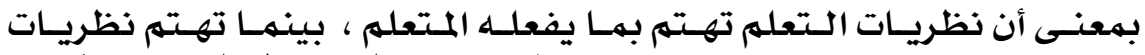

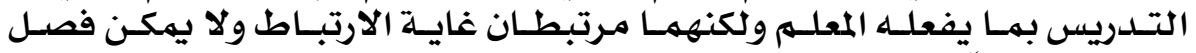

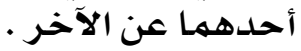

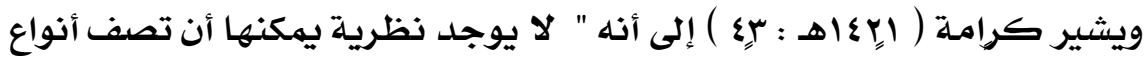

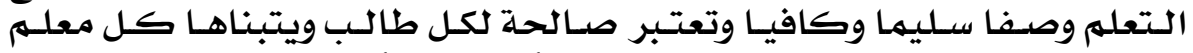

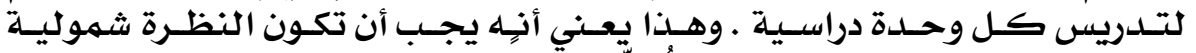

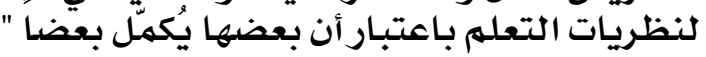

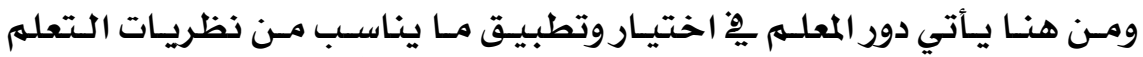

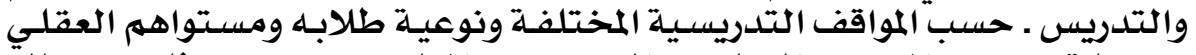

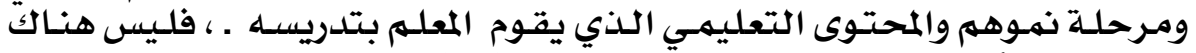

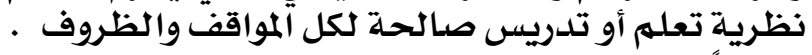

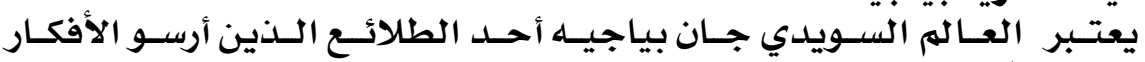

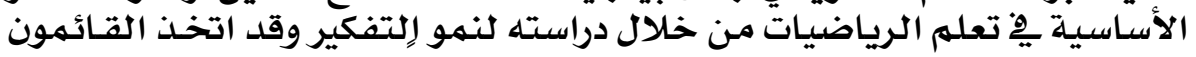

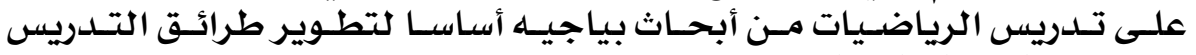

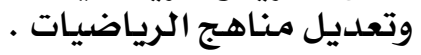

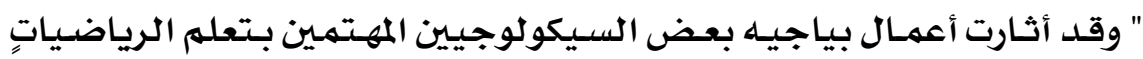

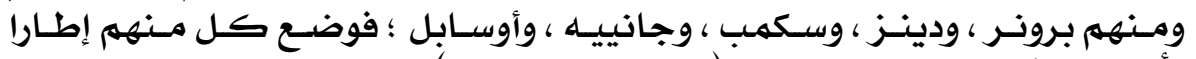

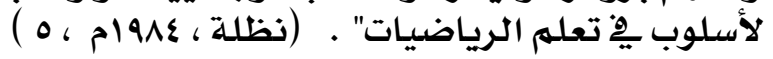

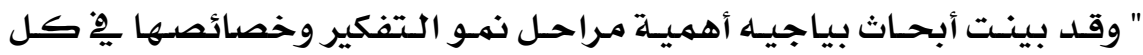

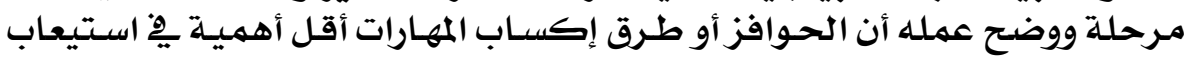

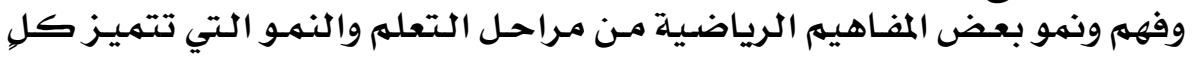

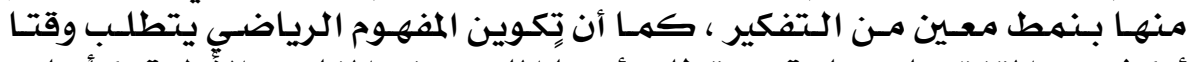

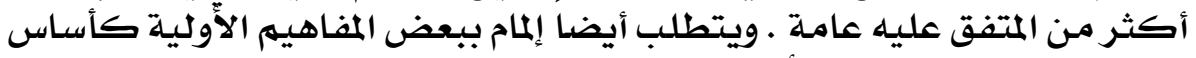

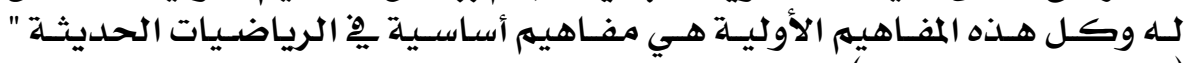

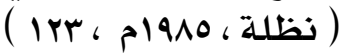

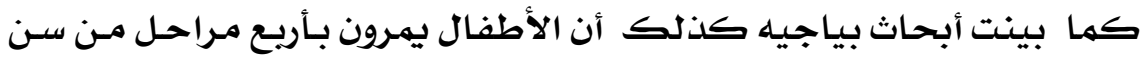

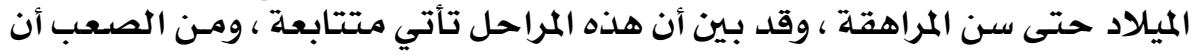

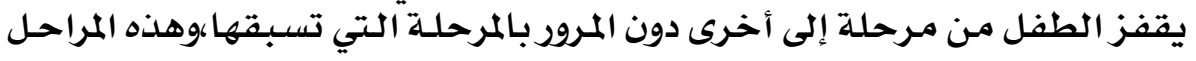

\section{$17 Y$}




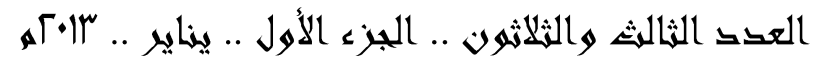

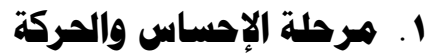

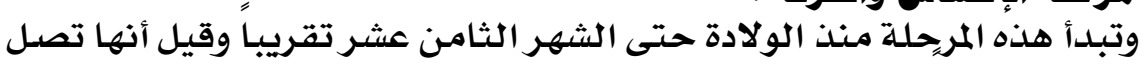

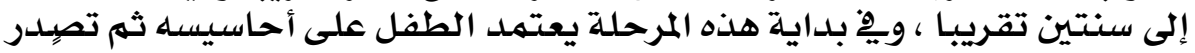

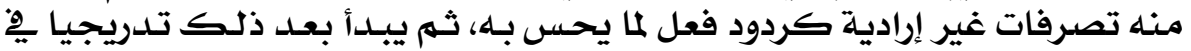
تطوير ردود الفعل.

وقد ذكر الحسن ( •و9 ام : وه ) ) أن بياجيه قسم هذه المرحلة إلى ست مراحل

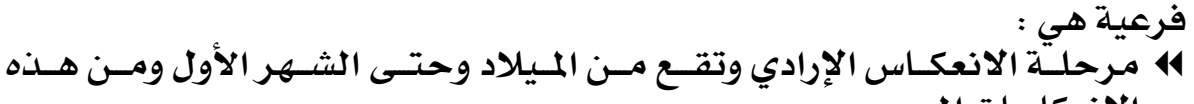

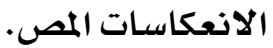
4 هرحلة الاستجابات الرئيسية غير المباشرة مـن شهر حتى أربعة أشهر وتتميز

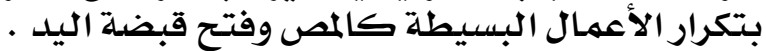

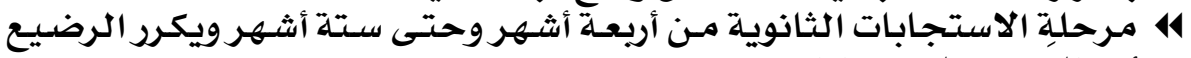

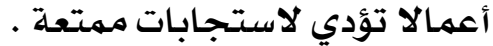
4 تناسق الاستجابات الثانوية من سبعة أشهر حتى عشرة شهور ويستطيع حل

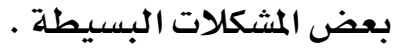

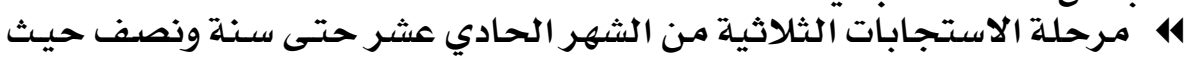

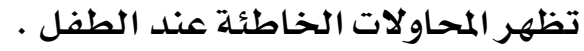

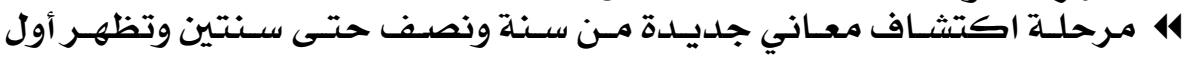
محاولة كل المثكلات عن طريق النشاط المعريو العقلي

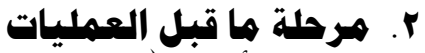

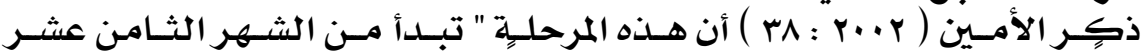

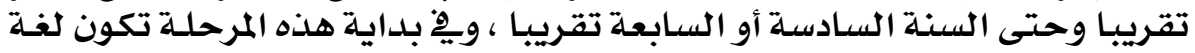

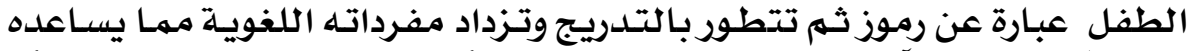

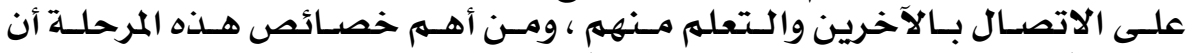

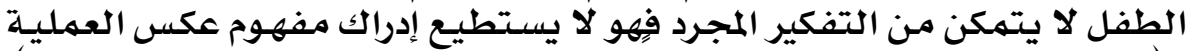

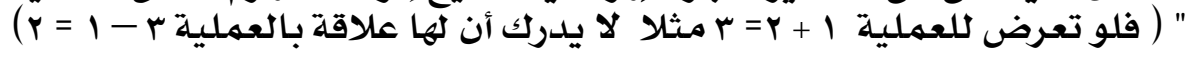

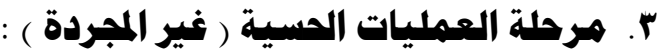

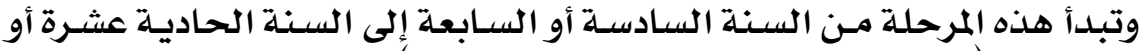

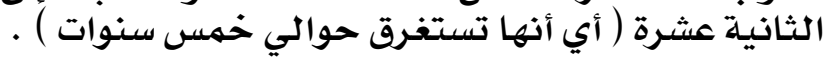

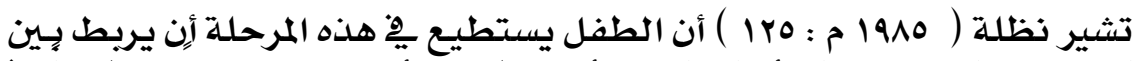

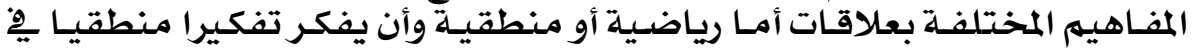

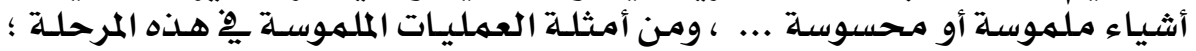

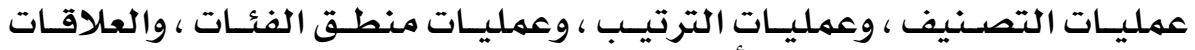
والعمليات الخاصلة بالفراغ والأعداد الترتيف

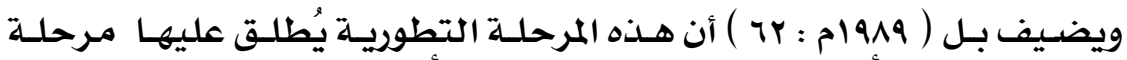

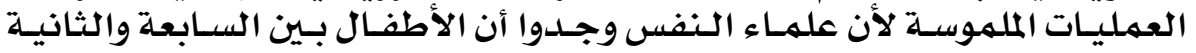

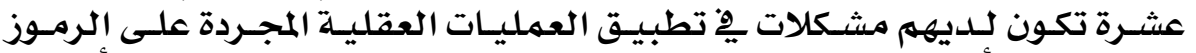

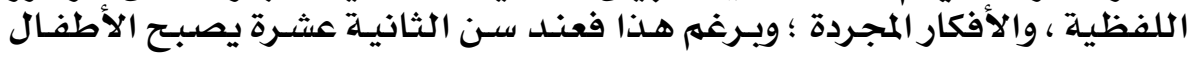

\section{$17 \%$}




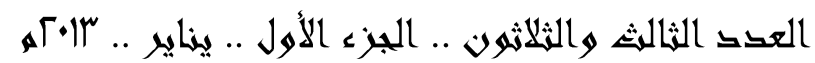

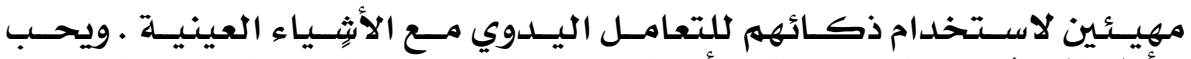

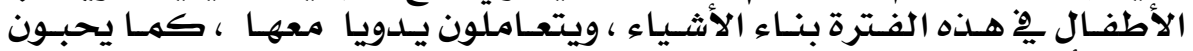
جعل الأشياء الميكانيكية تعهل .

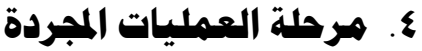

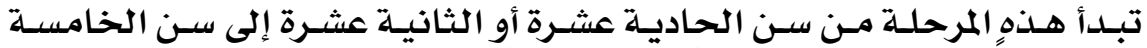

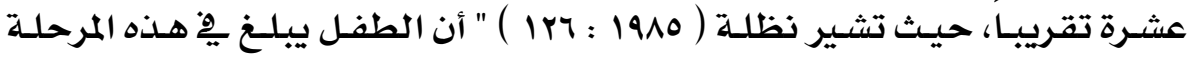

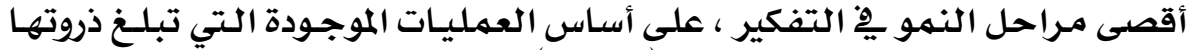

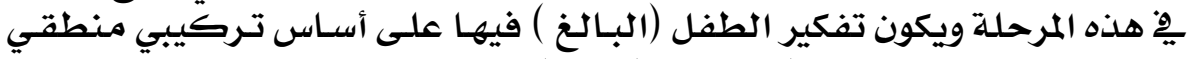

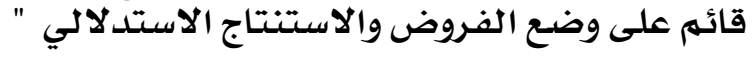

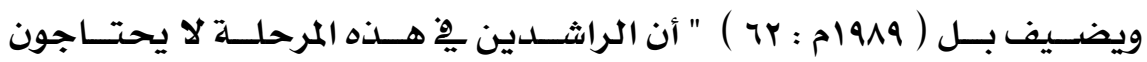

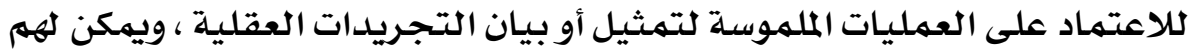

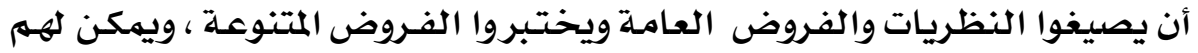

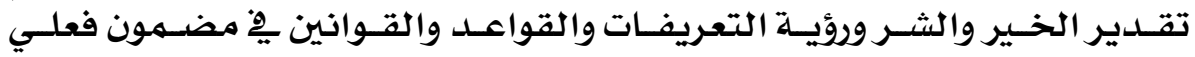

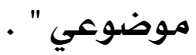

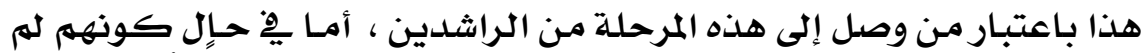

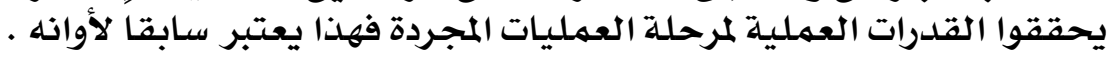

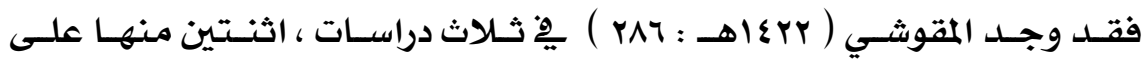

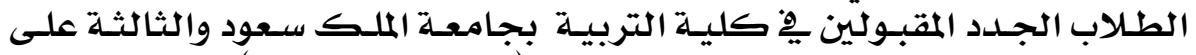

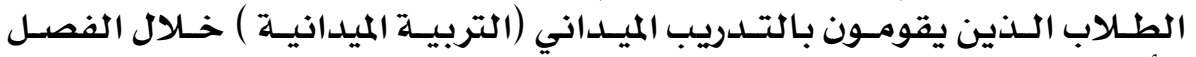

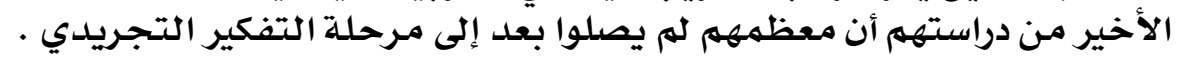

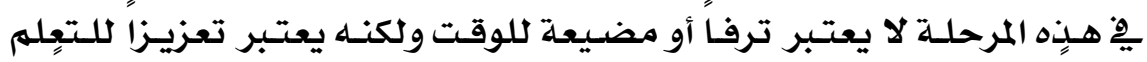

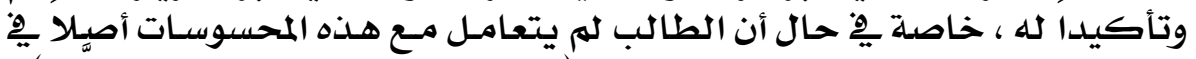

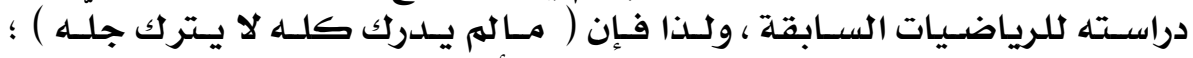

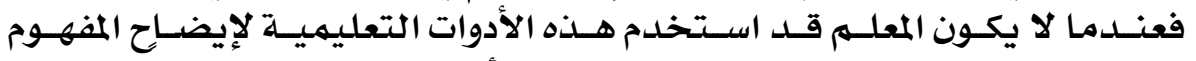

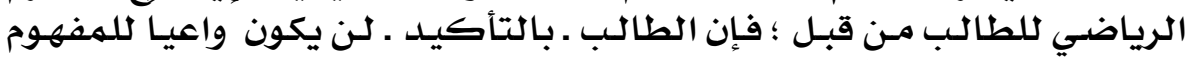

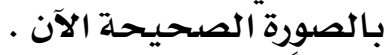

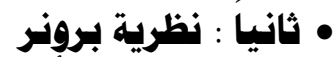

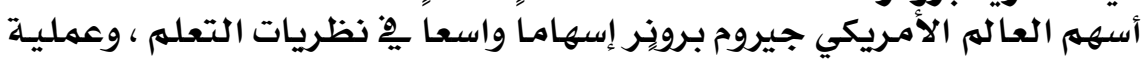

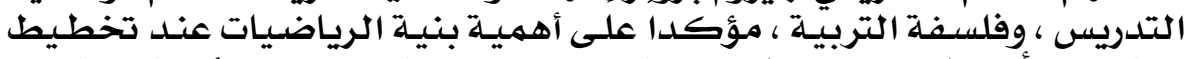

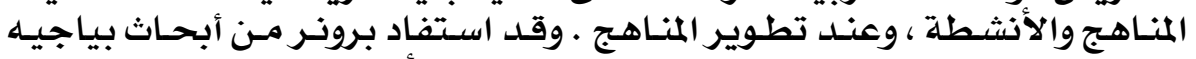

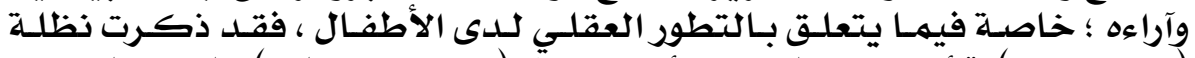

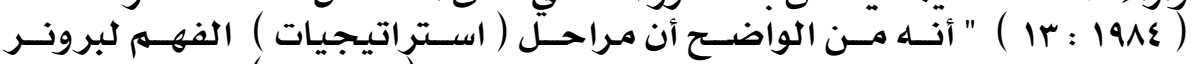

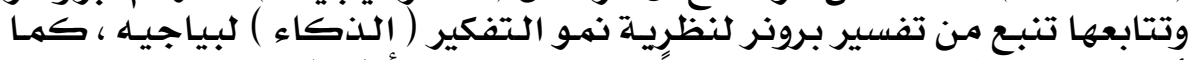

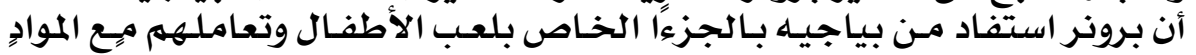

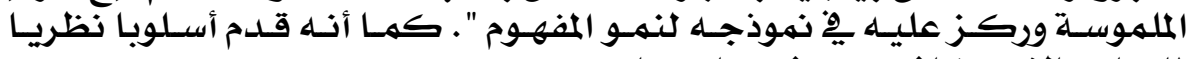

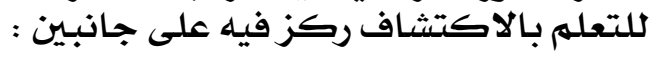

\section{$17 \varepsilon$}




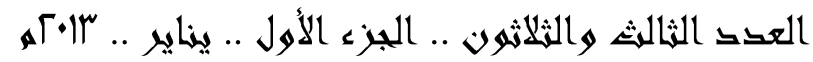

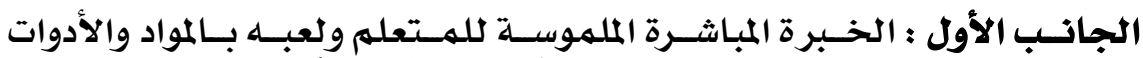

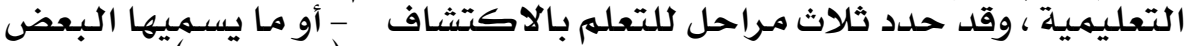

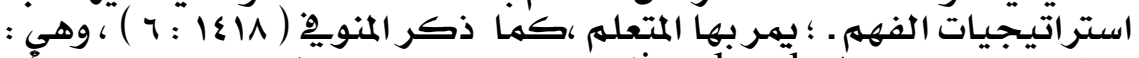

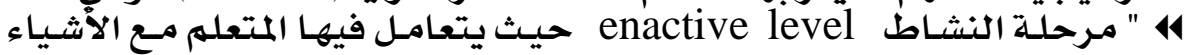

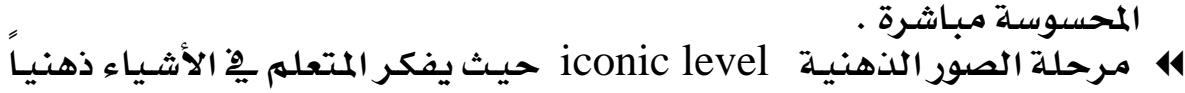

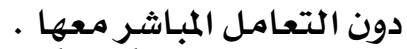

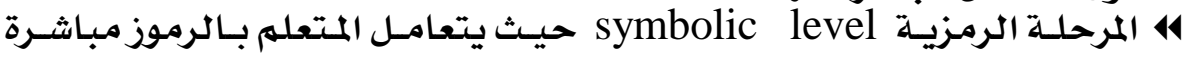
بطريق مجردة " المردئ

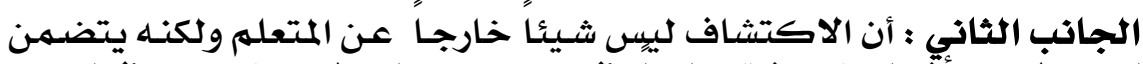

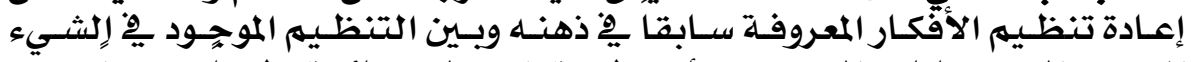

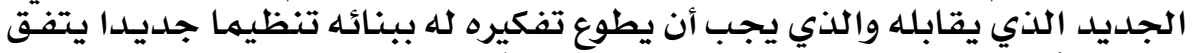

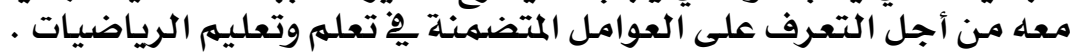

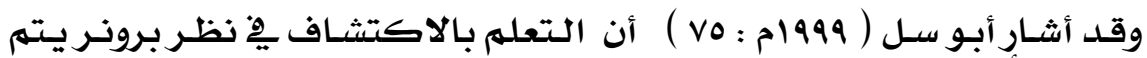

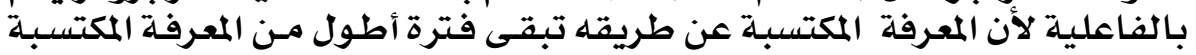

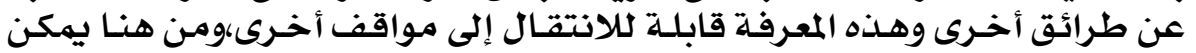

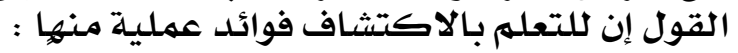

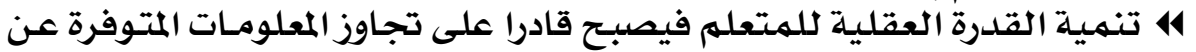

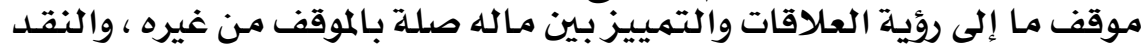

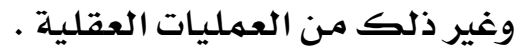

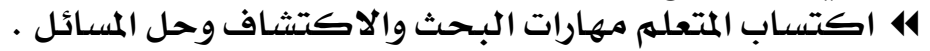

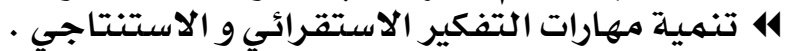

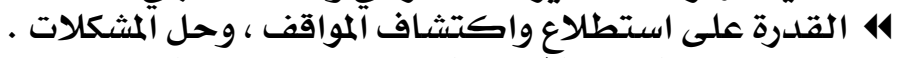

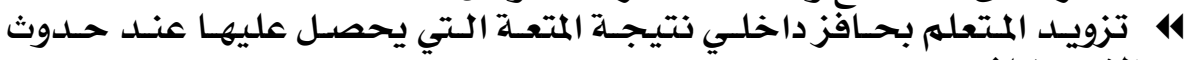

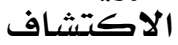
14 زيادة الثقة بالنفس عند المتعلهم .

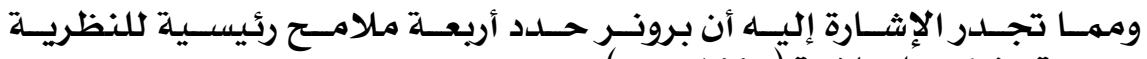

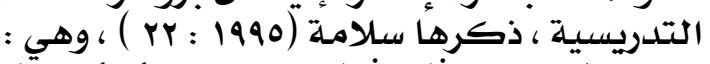

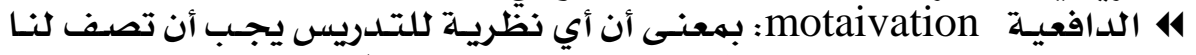

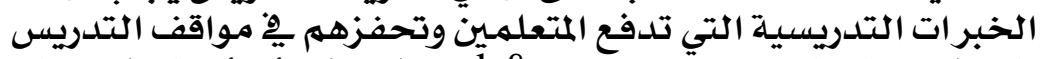

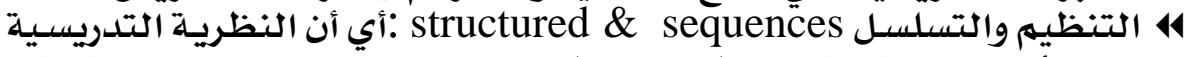

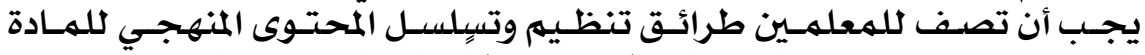

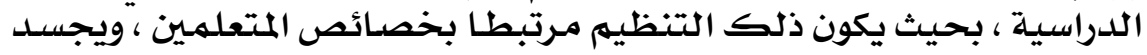

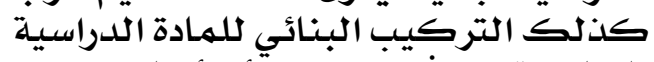

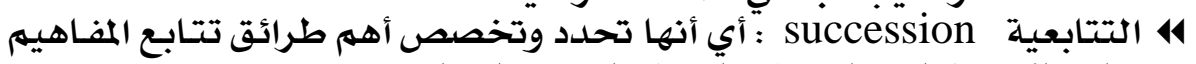

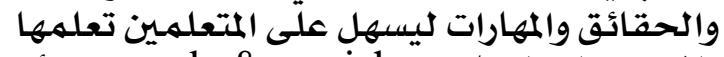

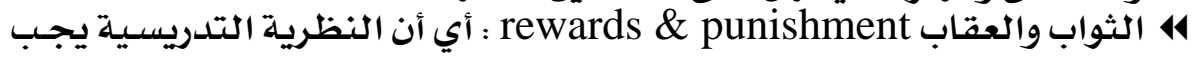

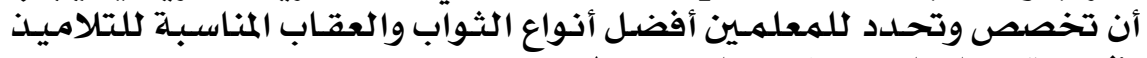

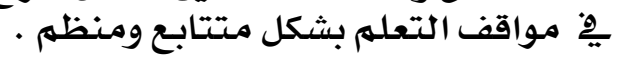

\section{0}




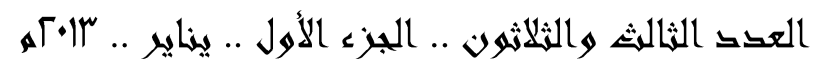

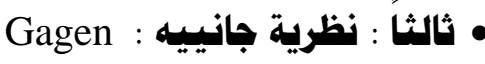

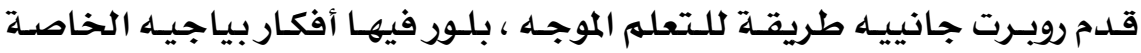

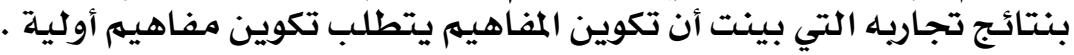

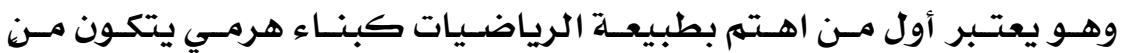

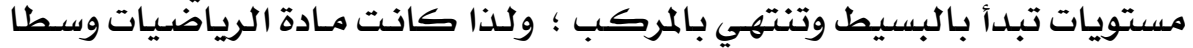

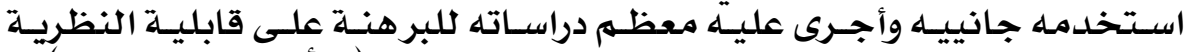

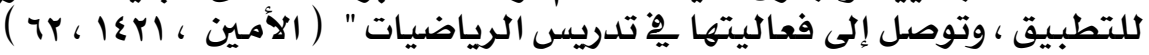

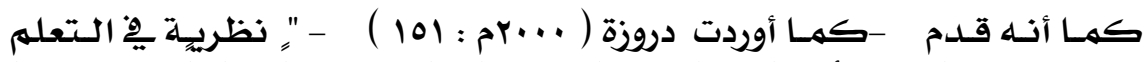

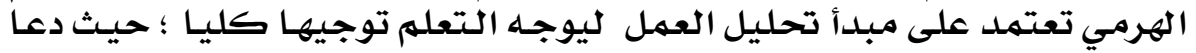

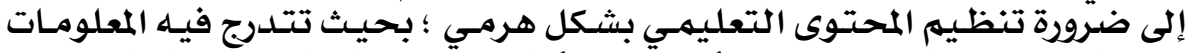

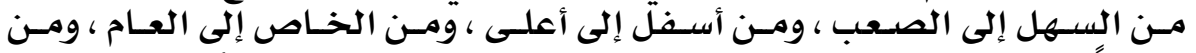

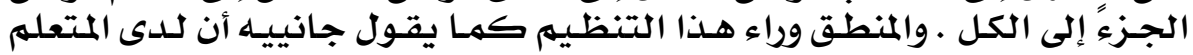

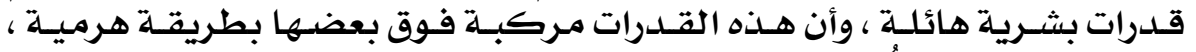

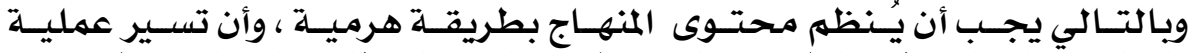

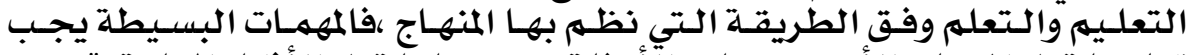

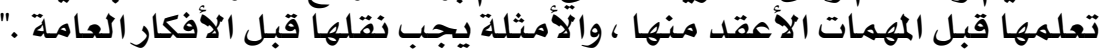

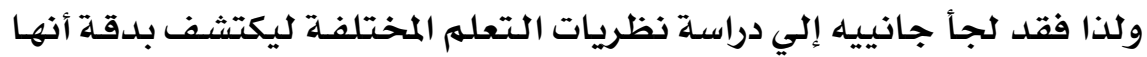

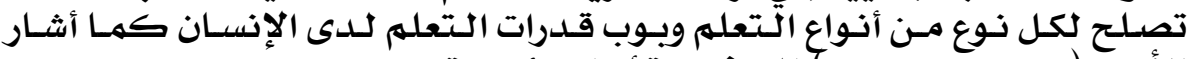

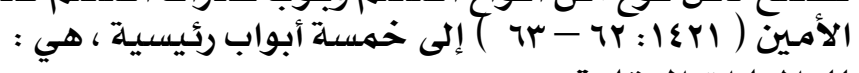

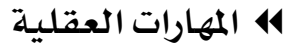

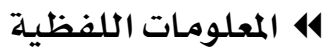

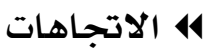

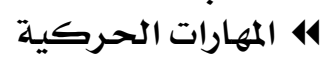

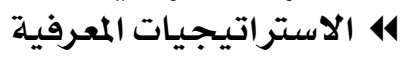

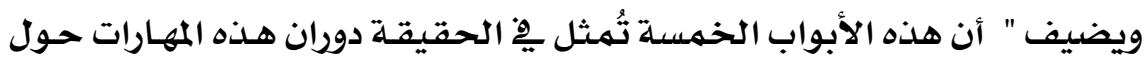

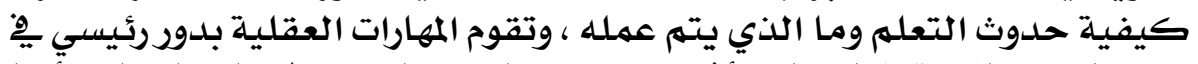

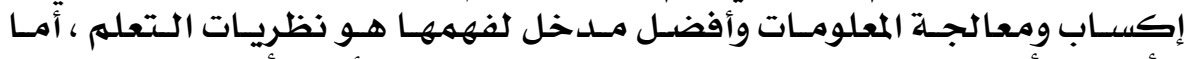

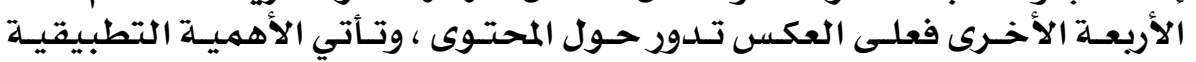

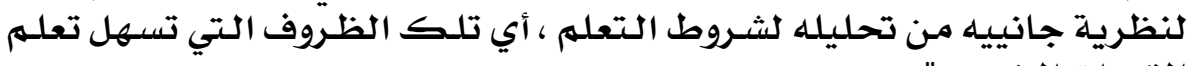

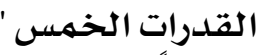

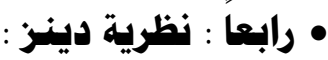

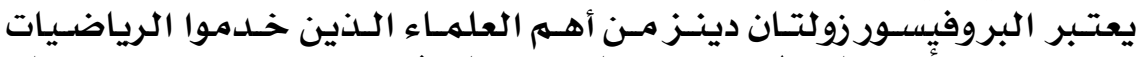

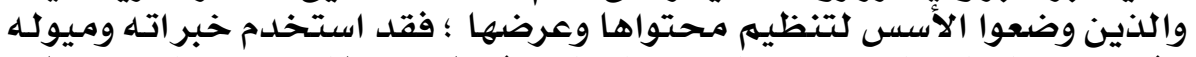

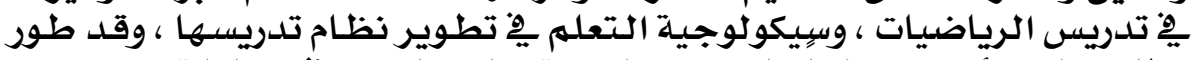

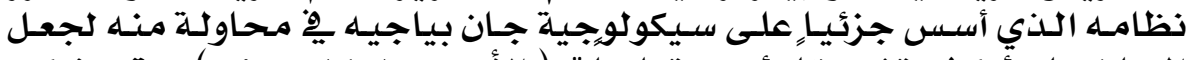

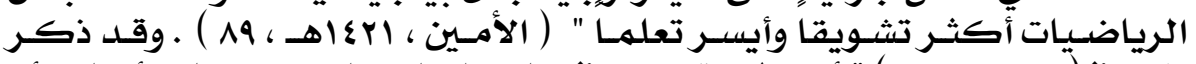

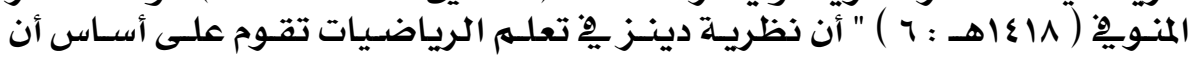

\section{7}




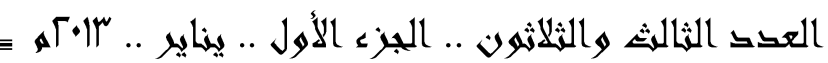

التعلم يسير يِّ دورات متعاقبـة كل دورة تتكون مـن ثلاث مراحل هي : اللعب ،

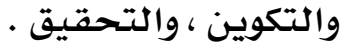

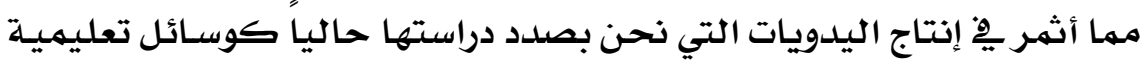

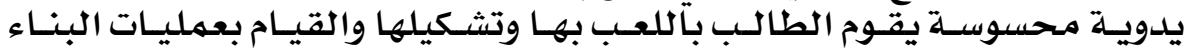

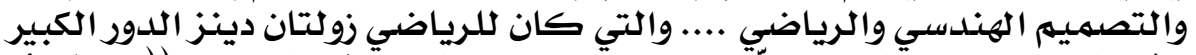

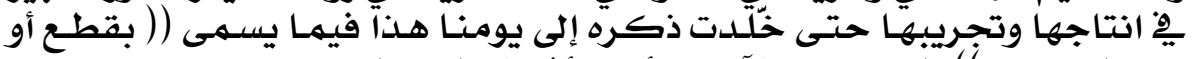

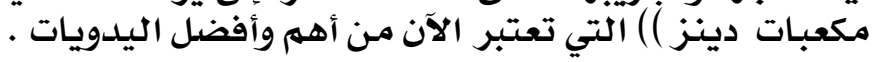

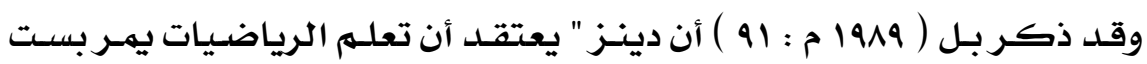

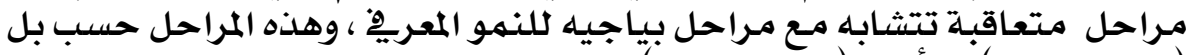

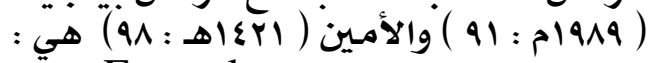

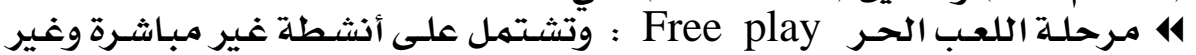

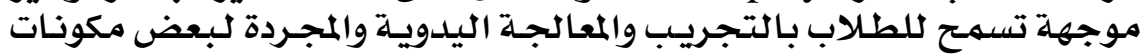

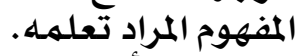

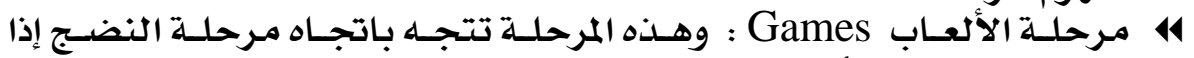

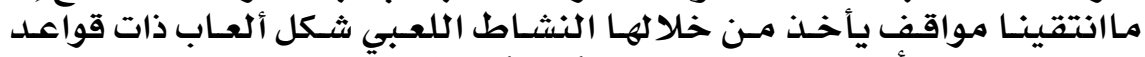

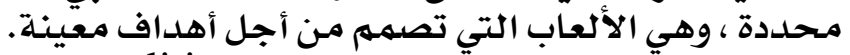

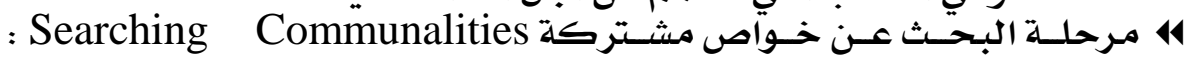

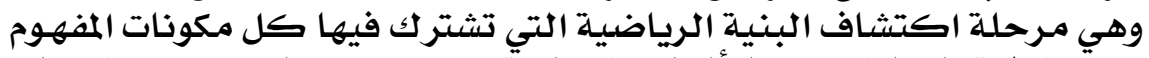

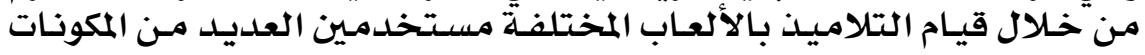

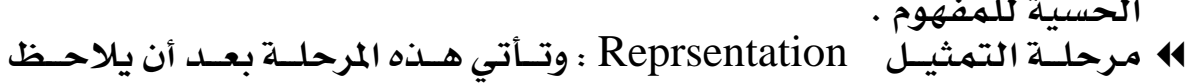

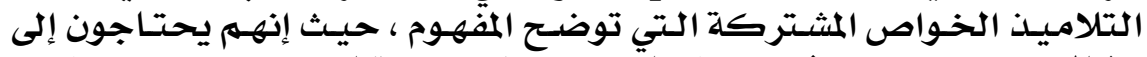

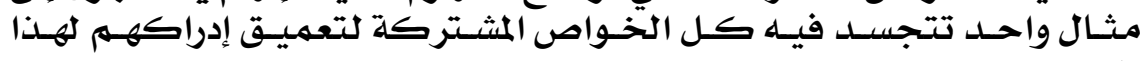

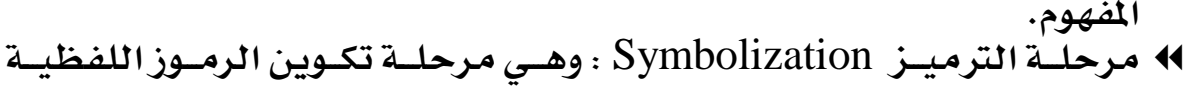

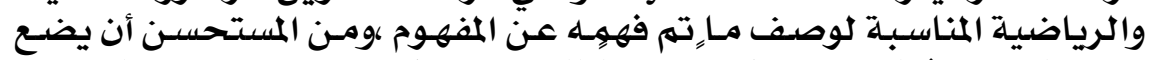

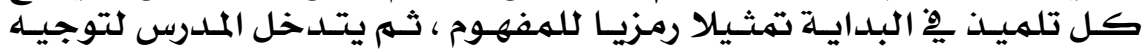

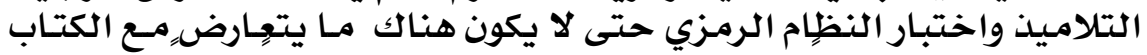

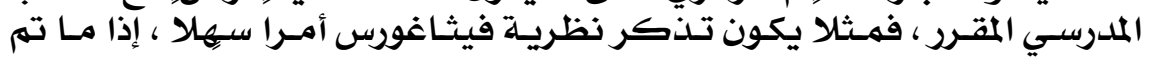

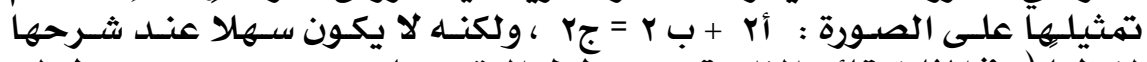

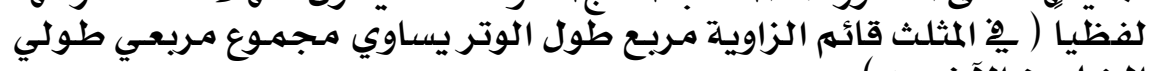

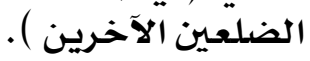

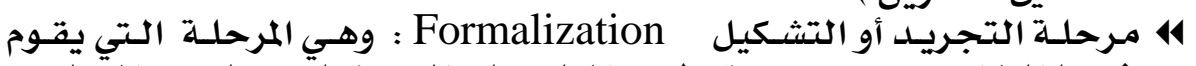

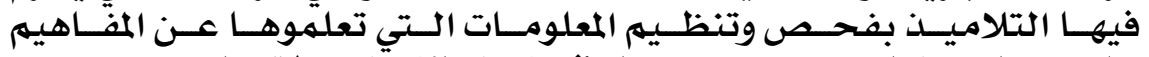

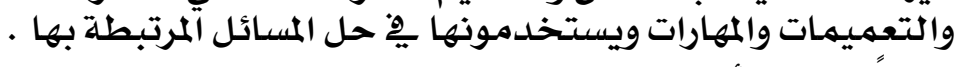

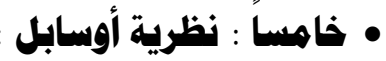

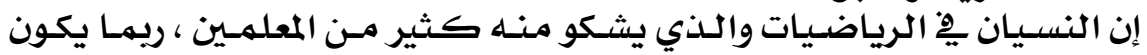

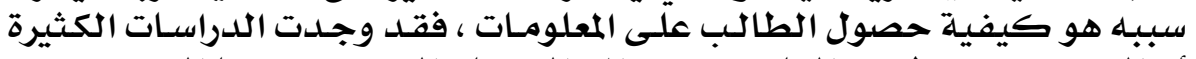
أن التـدريس عن طريق التلقين يقود إلى النسيان السـريع ، بينما التـريس مـن

\section{$17 \mathrm{~V}$}




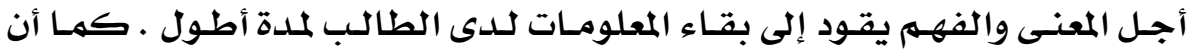

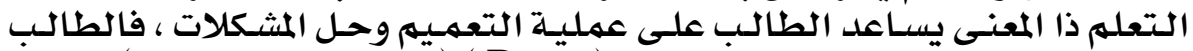

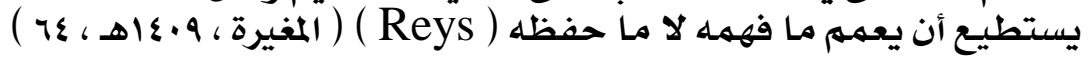

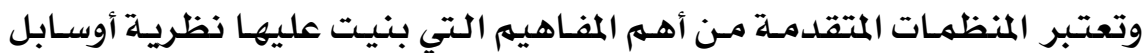

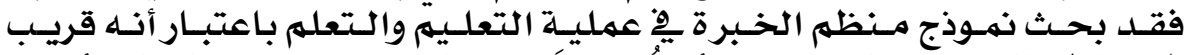

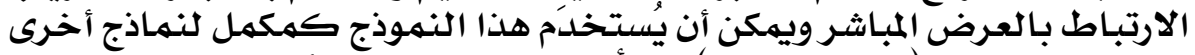

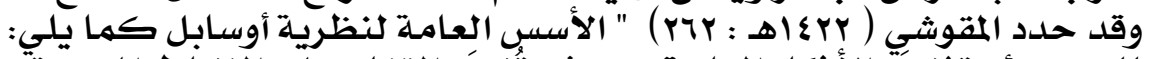

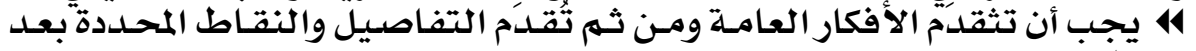

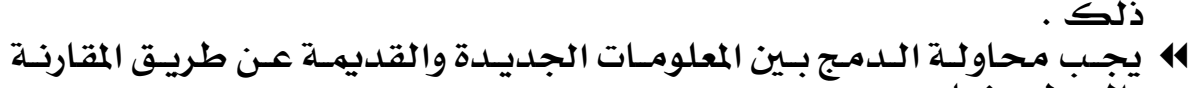

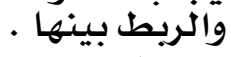

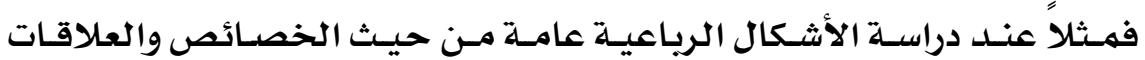

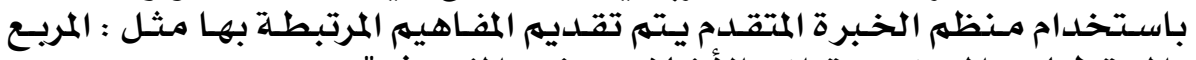

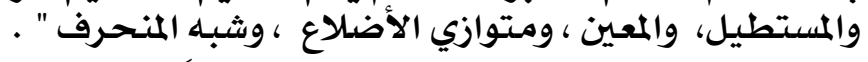

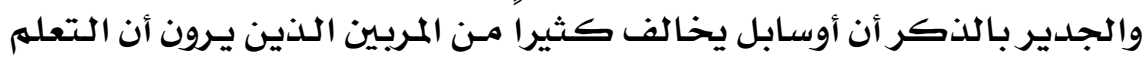

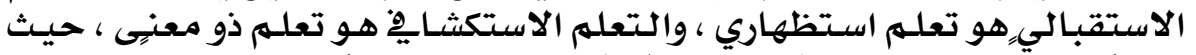

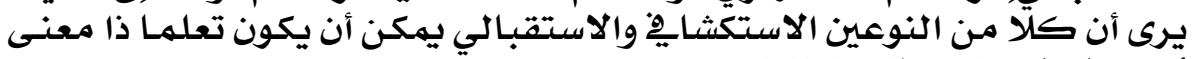

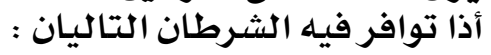

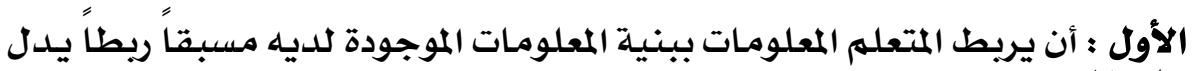

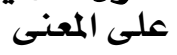

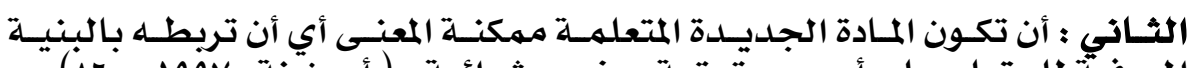

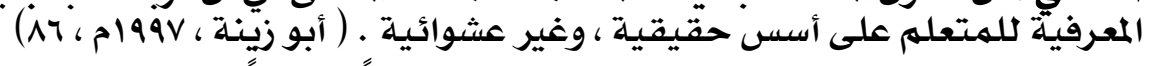

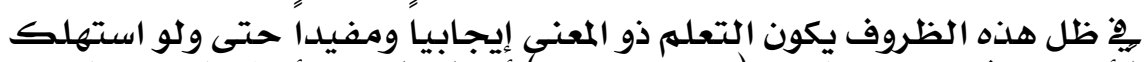

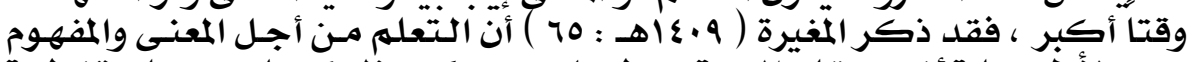

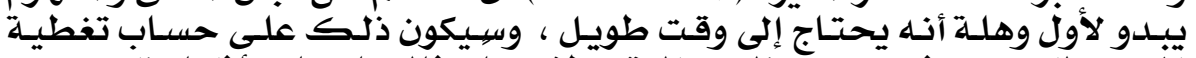

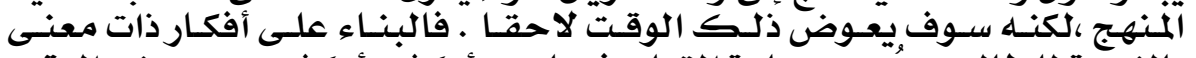

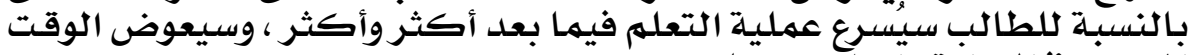

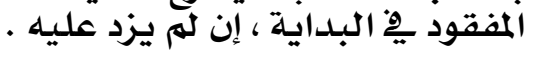

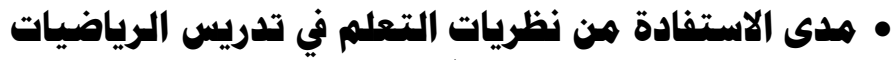

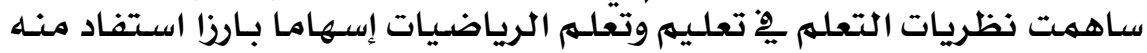

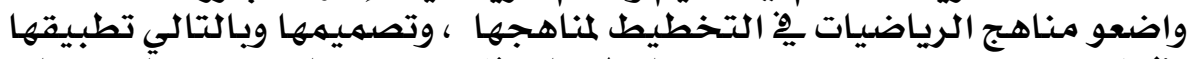

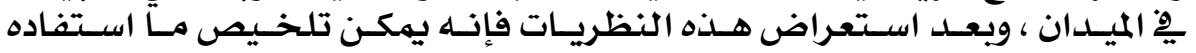

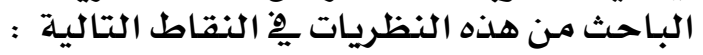

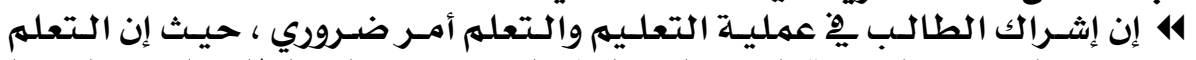

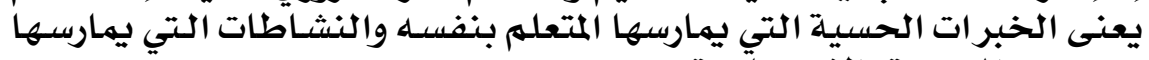

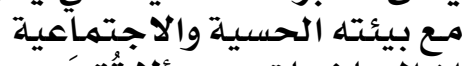

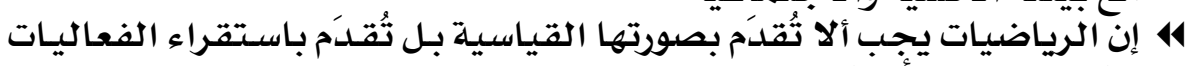

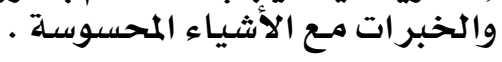

\section{1}




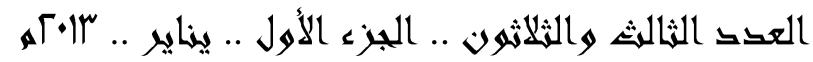

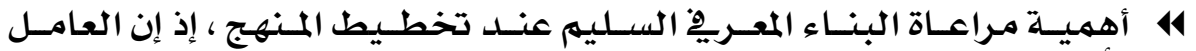

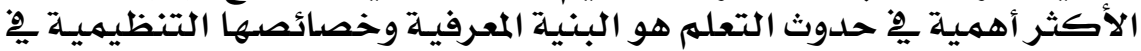

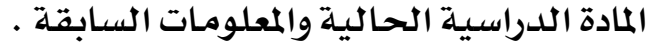

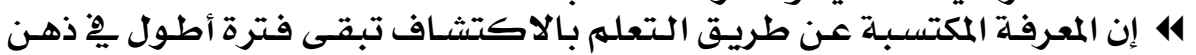

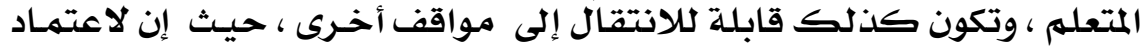

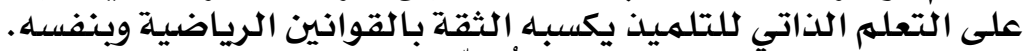

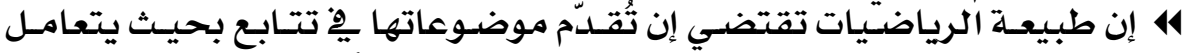

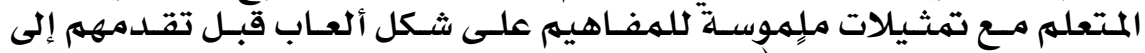

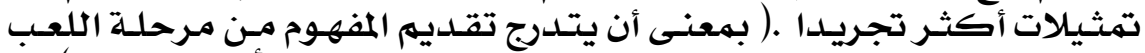

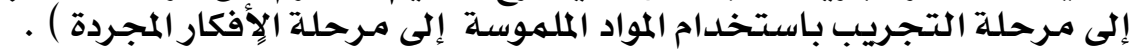

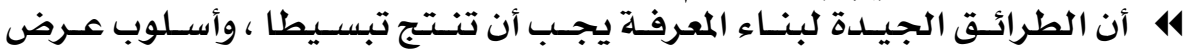

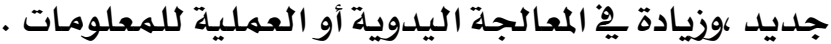
414

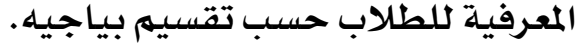

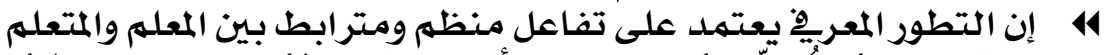

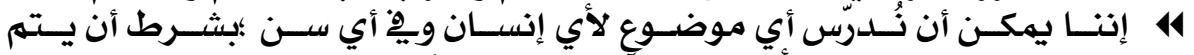

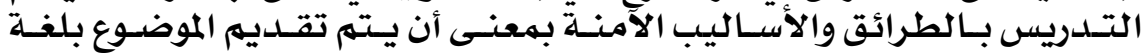

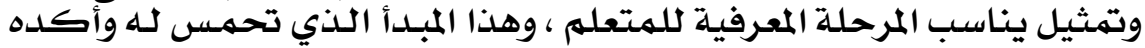

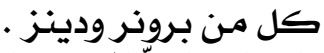

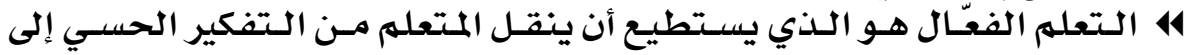

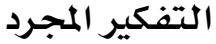

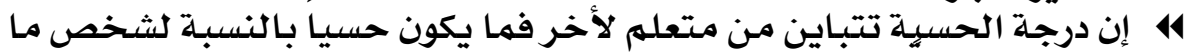

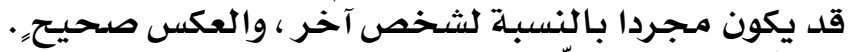

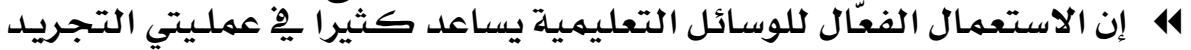

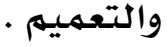

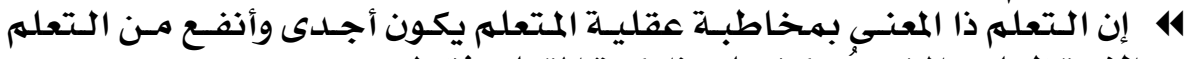

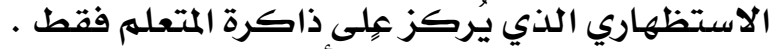

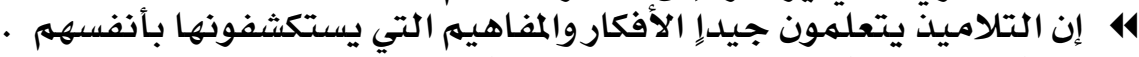

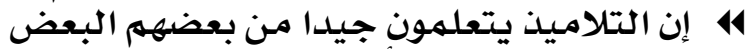

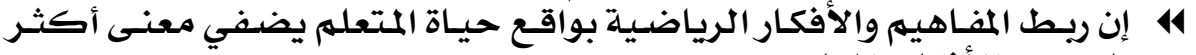

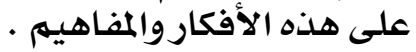
414

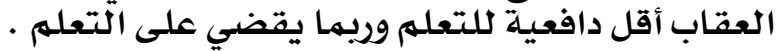

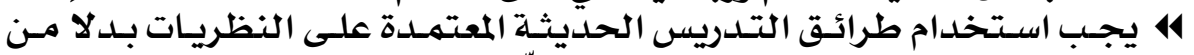

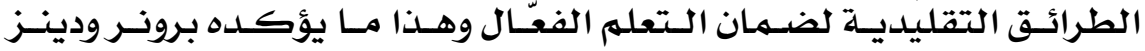

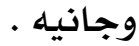

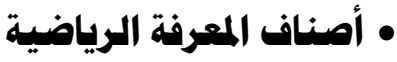

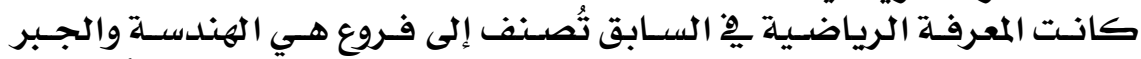

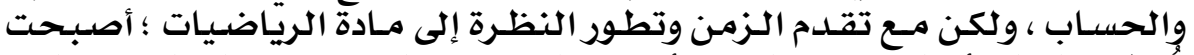

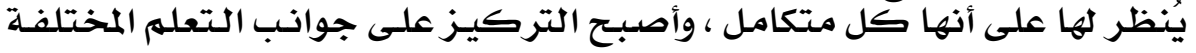

\section{9}




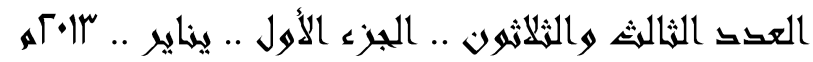

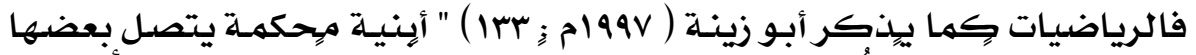

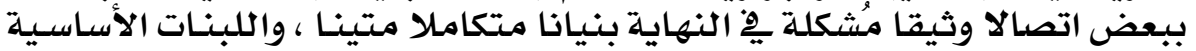

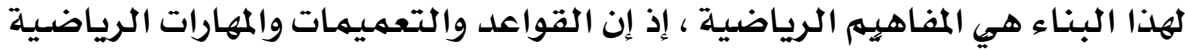

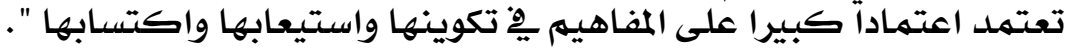

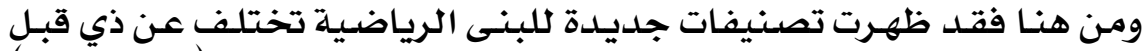

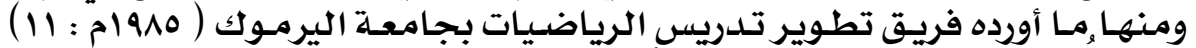

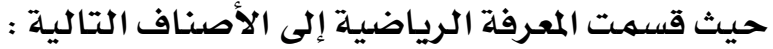

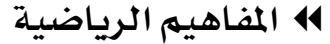
4 المبادئ والتعمييمات الرياضية الرياضية

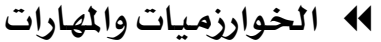
14 المسائل الرياضياتوالميارات

وسوف نتناول هذه الأصناف يِّ السياق التالي :

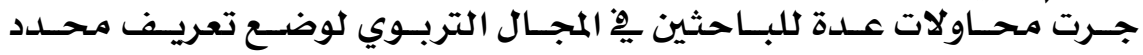

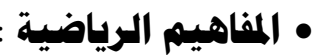

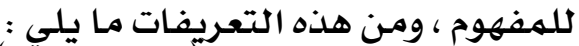

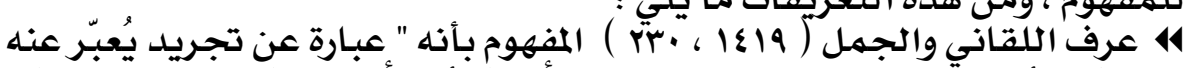

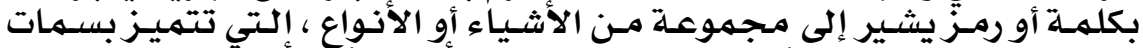

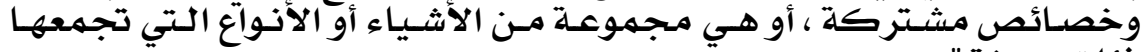

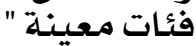

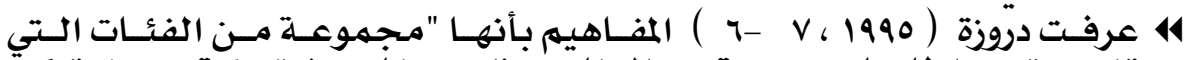

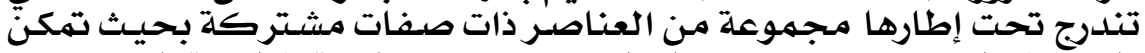

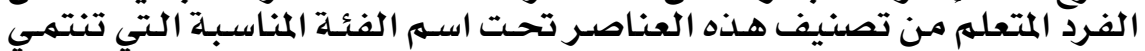

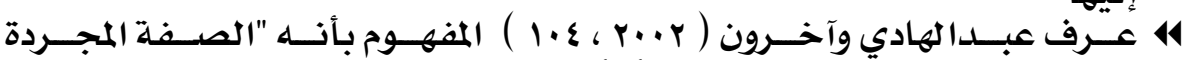

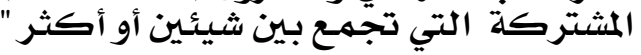

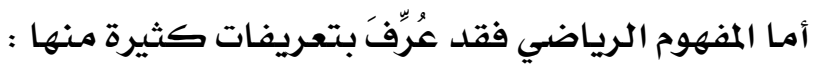

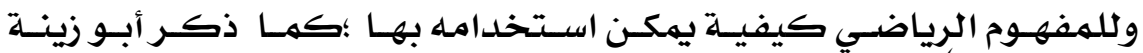

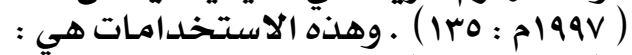

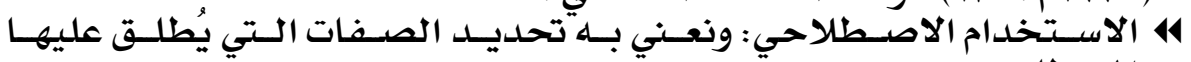

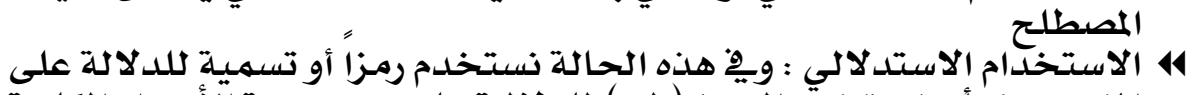

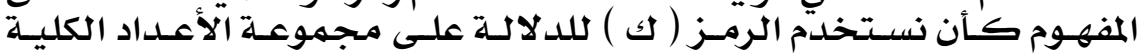

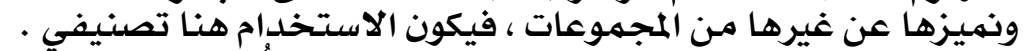

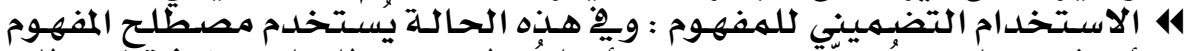

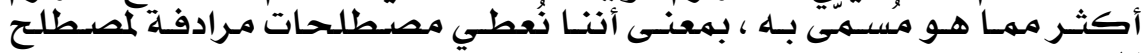

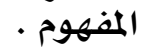

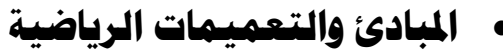

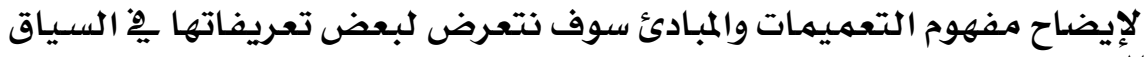

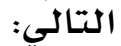

\section{$1 \mathrm{~V}$}




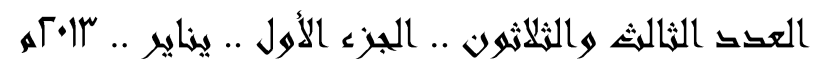

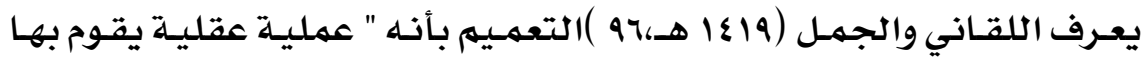

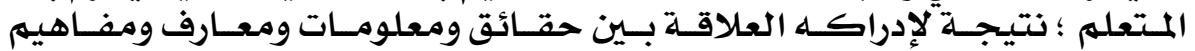

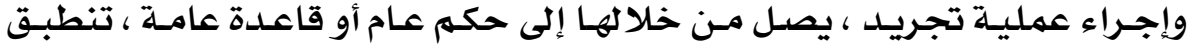

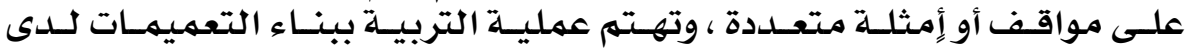

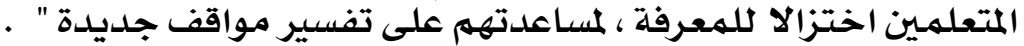

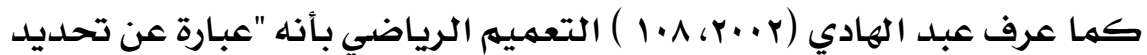

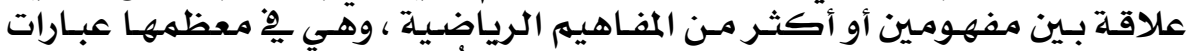

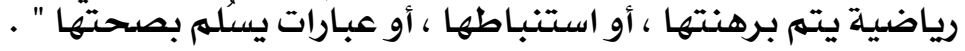

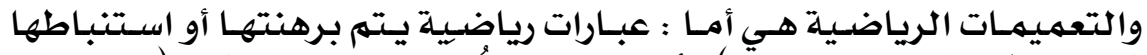

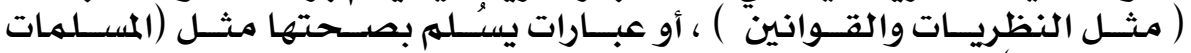
والبديهيات (ملثرات )

وتنقسم المبادئ والتعميمات الرياضية إلى قسمين كهما يذكرها عبد الهـادي : (1.9، r...r) 41 التعميمـات الكليـة Universal : وهـي التعميهـات الـتي تبــأ بكلهـة (كلـ أو

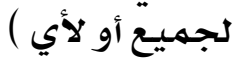

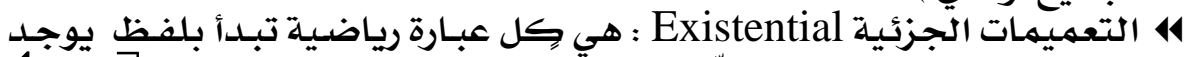

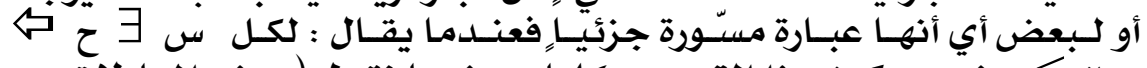

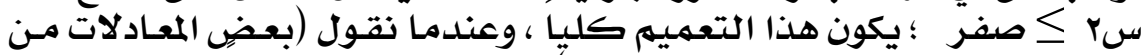

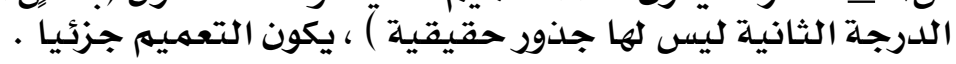

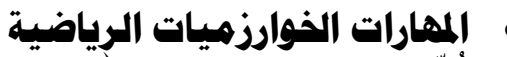

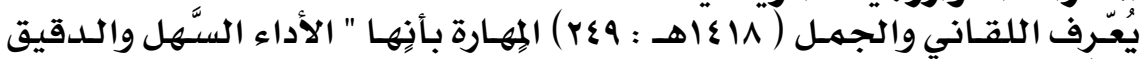

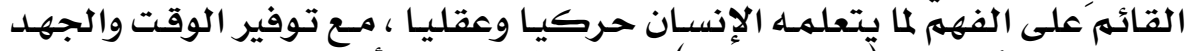

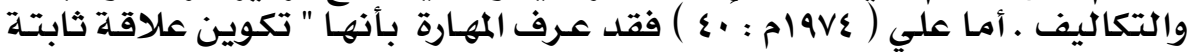

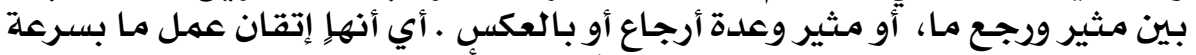

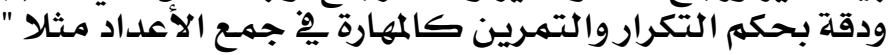

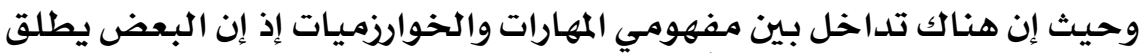

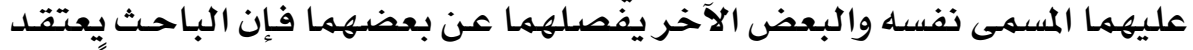

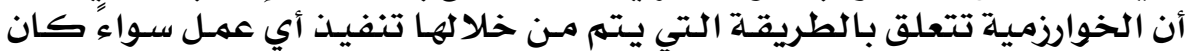

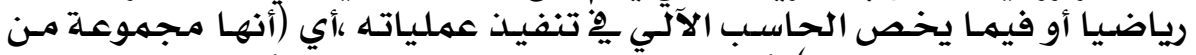

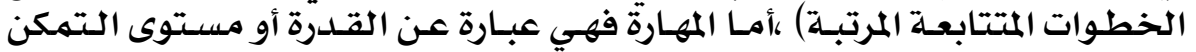

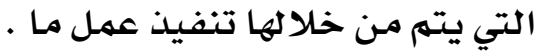

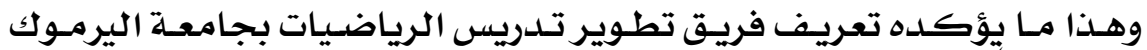

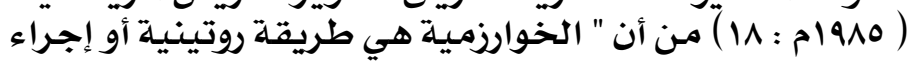

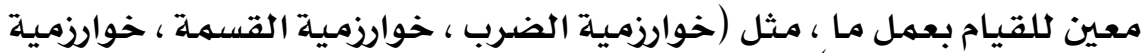

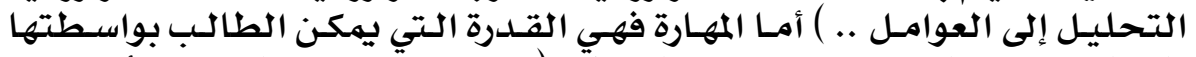

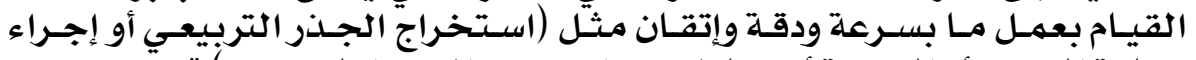

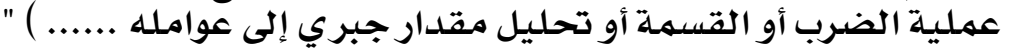




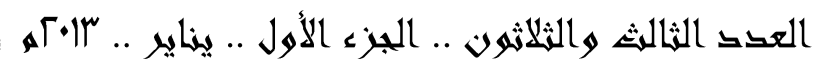

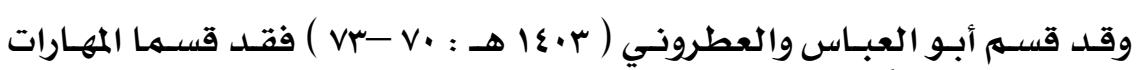
الرياضية إلى ثلاثة أقسام هي :

414 الفهم : وهو عملية معقدة ولها مستويات مختلفة تلتدرج مـن البسيط كفهـم

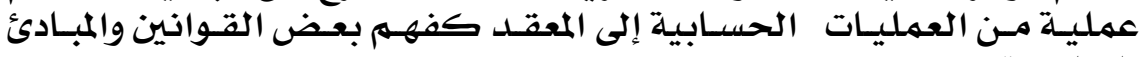
الرياضية الرية

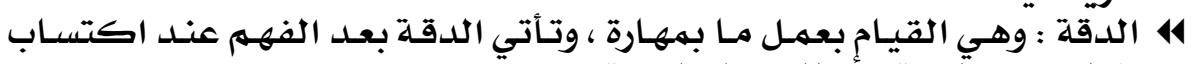

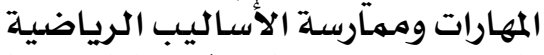

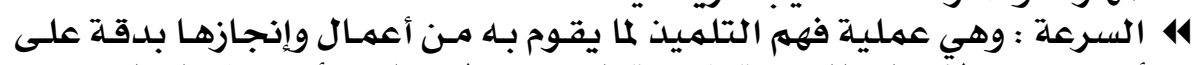

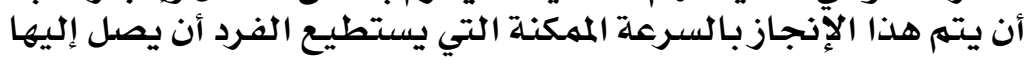

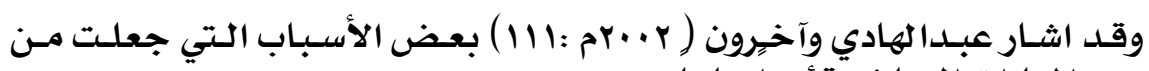

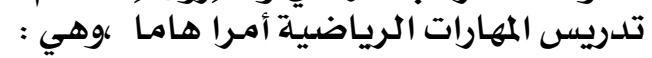

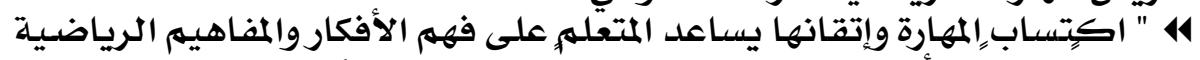

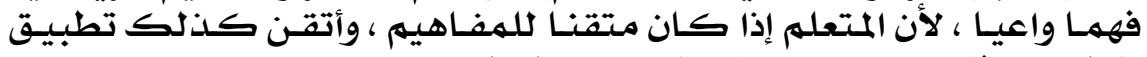

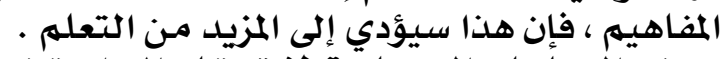

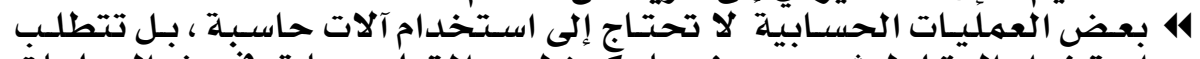

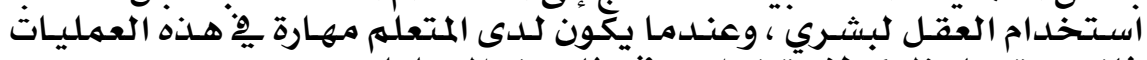

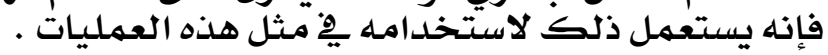

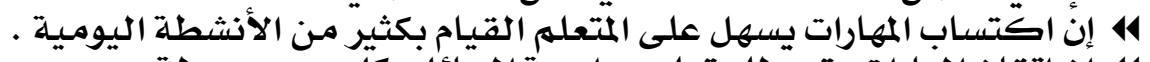

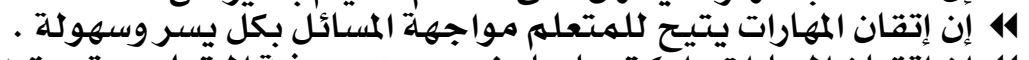

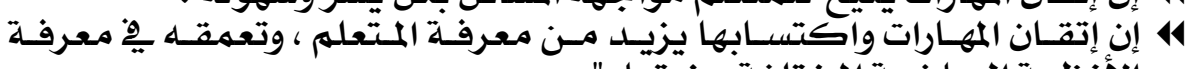

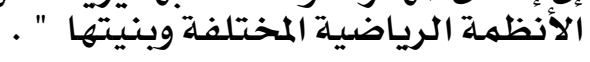

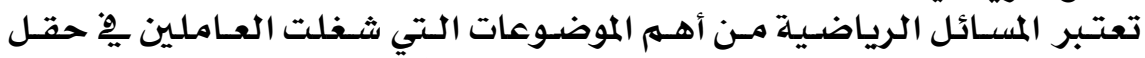

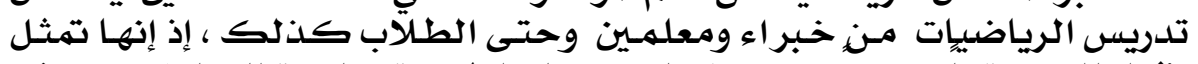

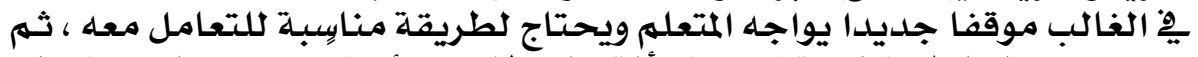

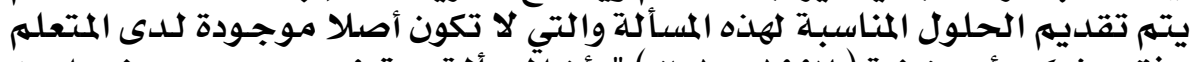

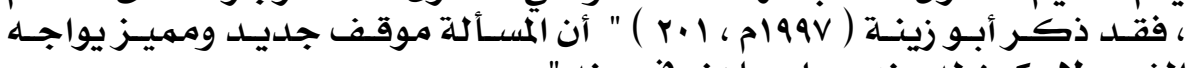

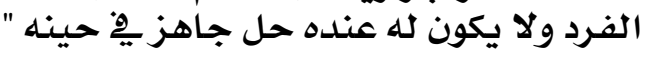

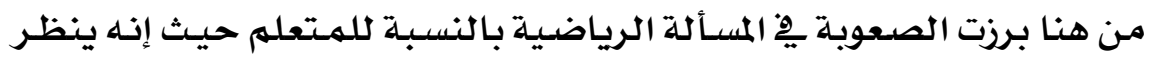

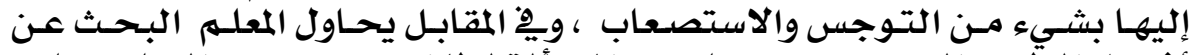

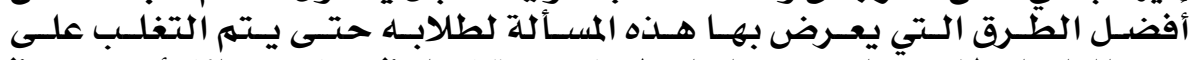

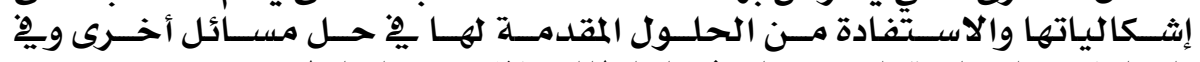

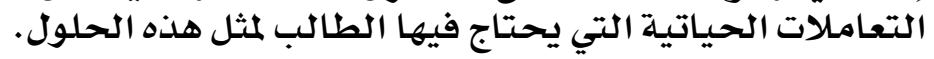

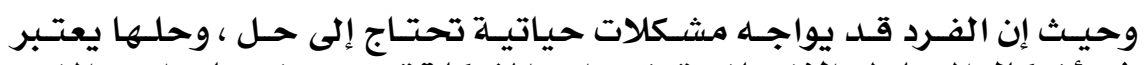

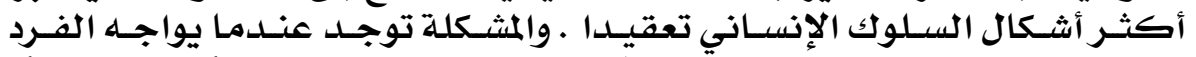

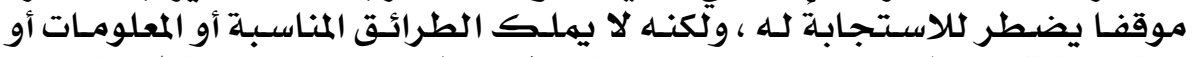

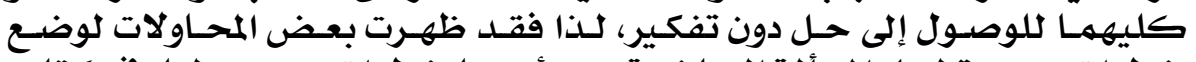

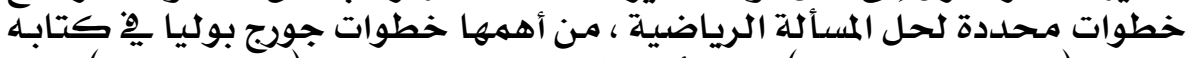

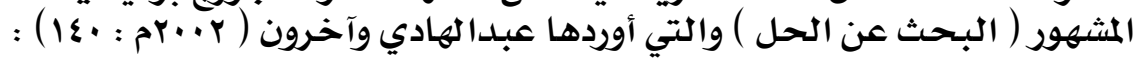

\section{IVY}

دوأهائت عربية في الثتربية وعثم النفسي (ASEP) 


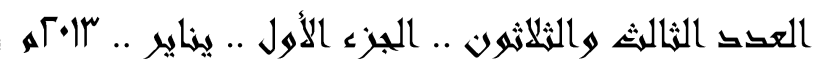

$$
14
$$

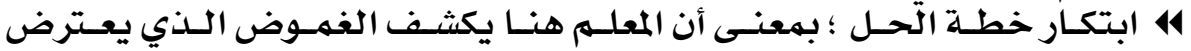

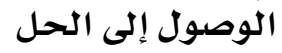

4ه تنفيذ الحل إلى الحرال

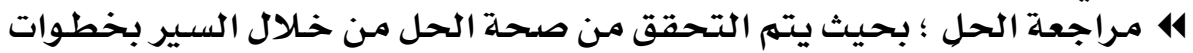

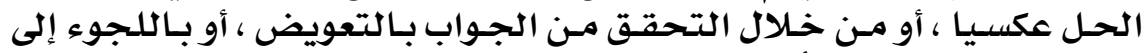

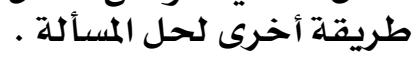

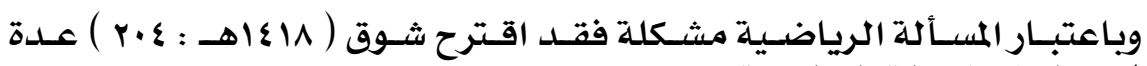

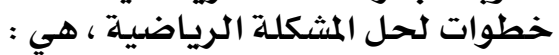

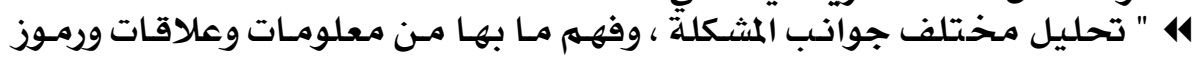

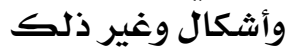

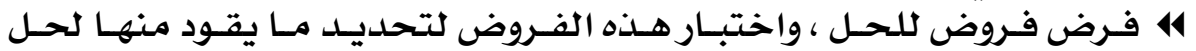

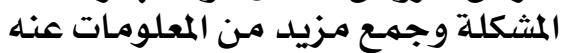

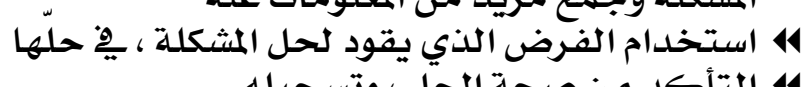

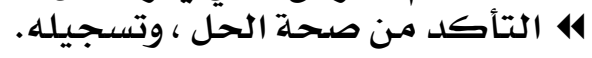

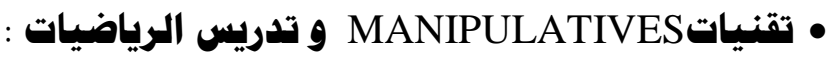

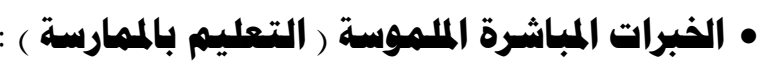

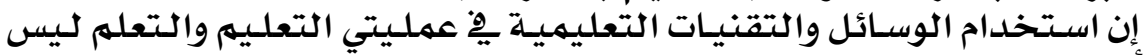

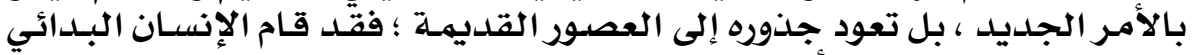

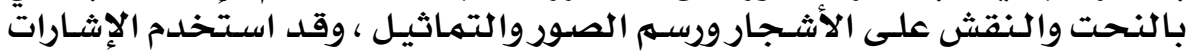

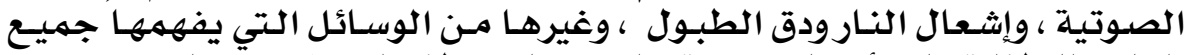

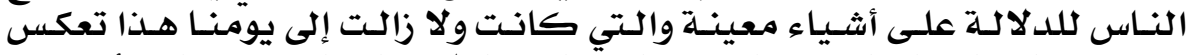

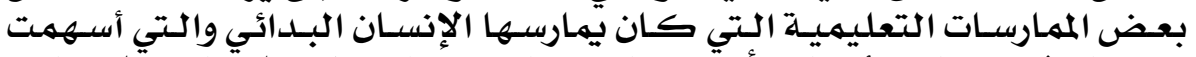

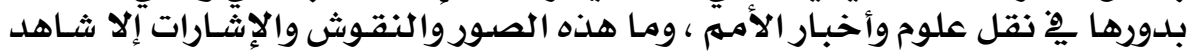

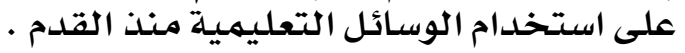

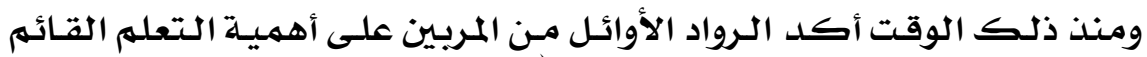

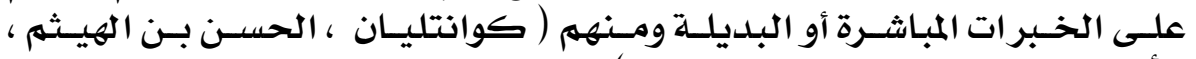

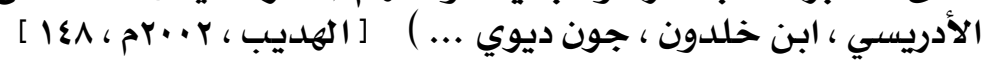

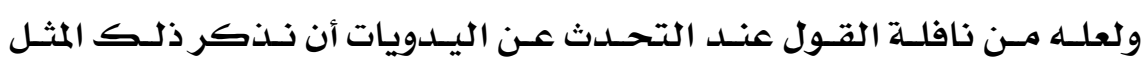

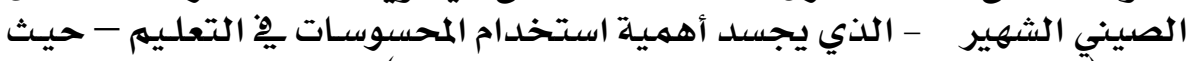

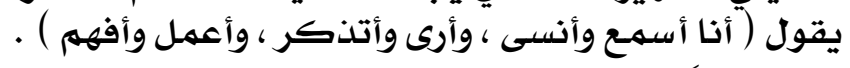

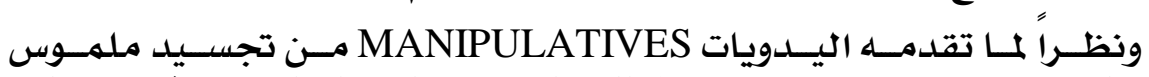

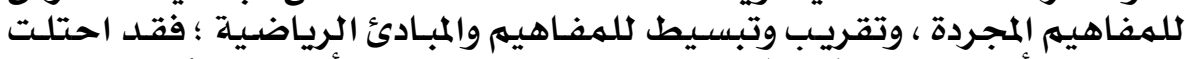

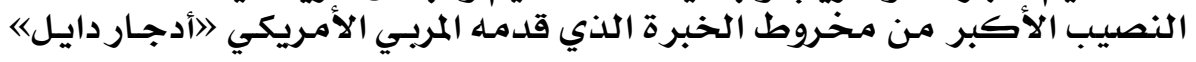

\section{IVY}

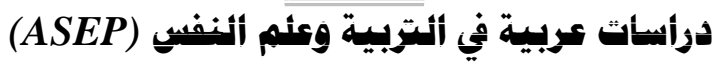




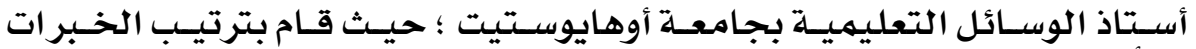

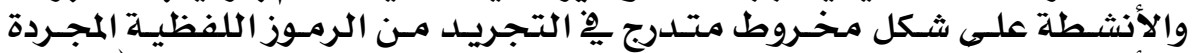

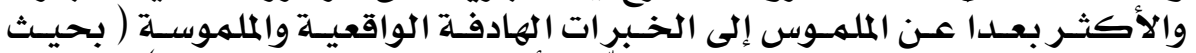

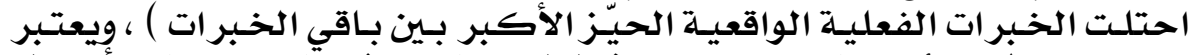

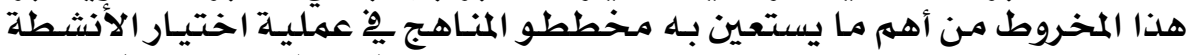

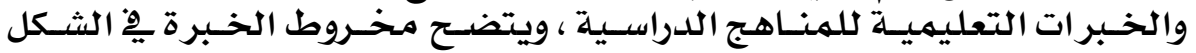
التتالي :

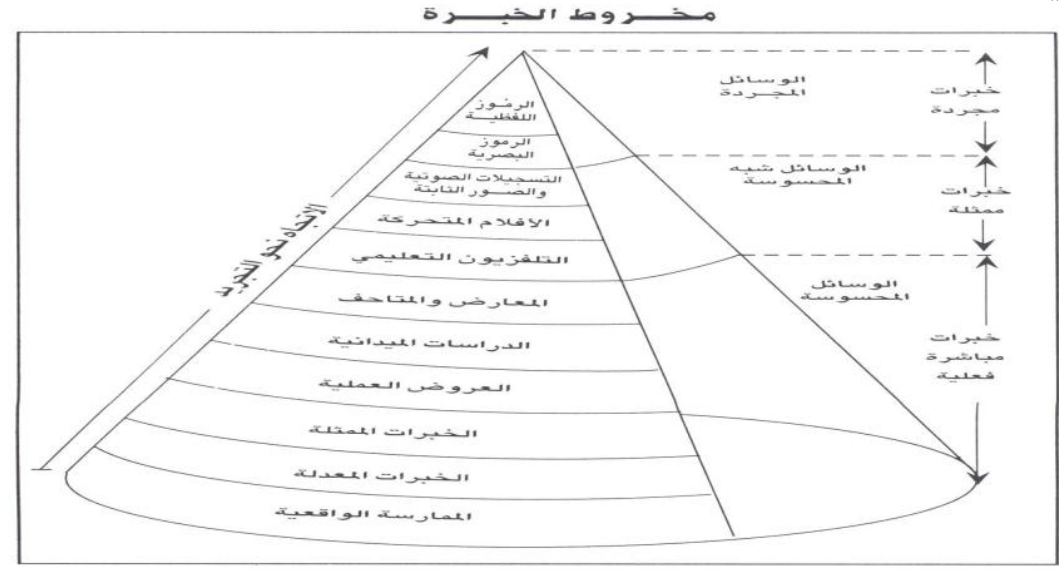

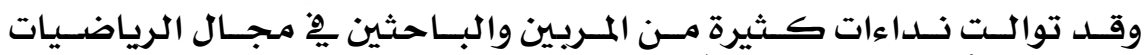

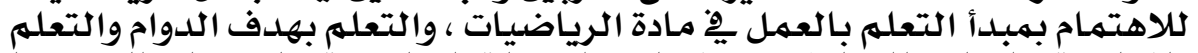

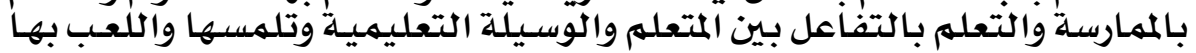

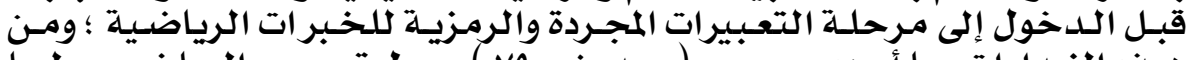

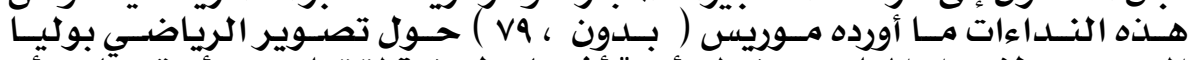

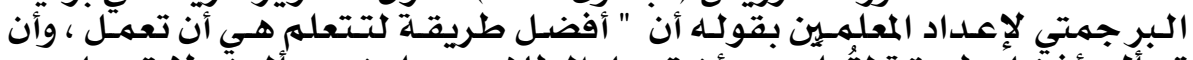

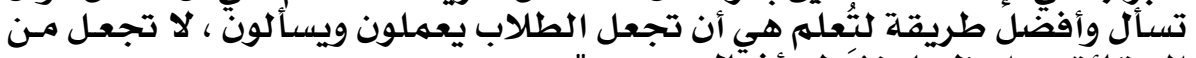

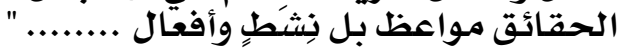

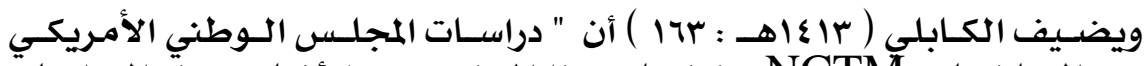

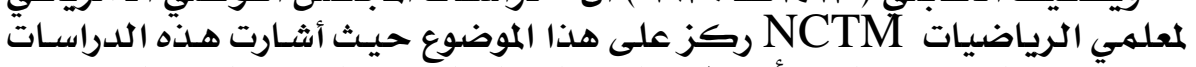

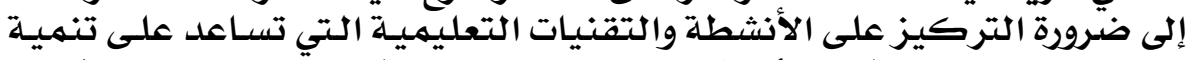

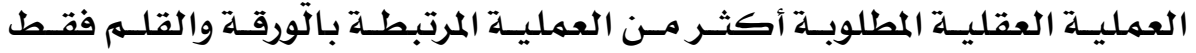

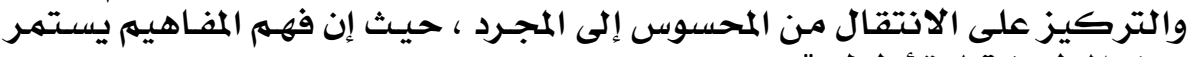

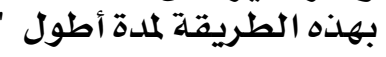

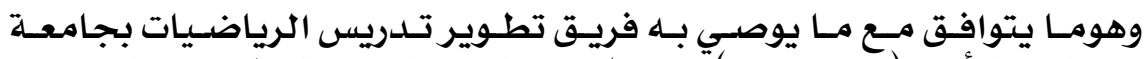

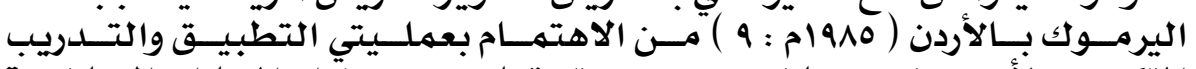

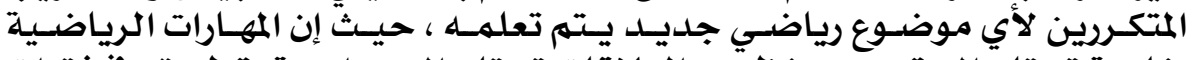

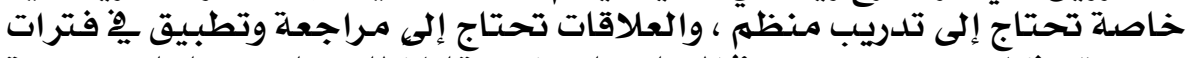

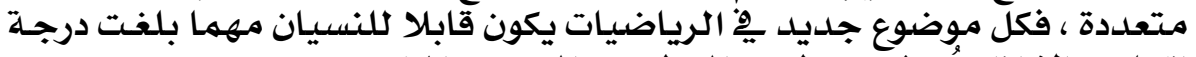

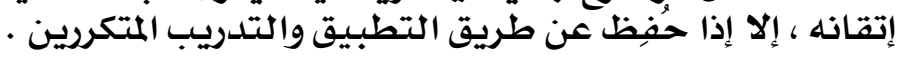

\section{$1 \vee \varepsilon$}




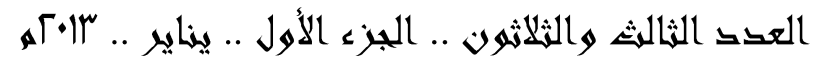

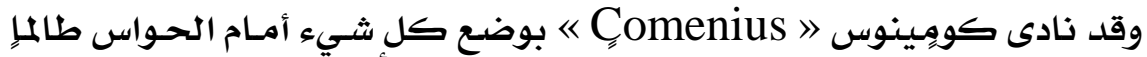

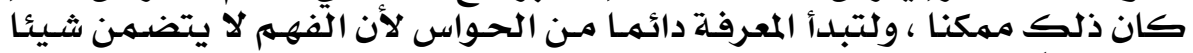

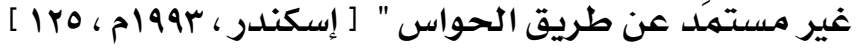

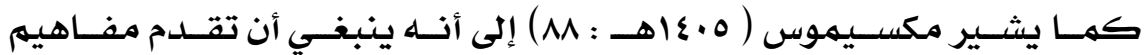

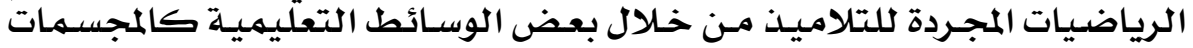

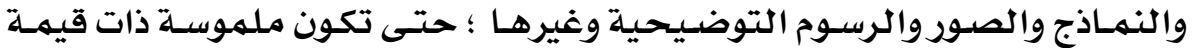

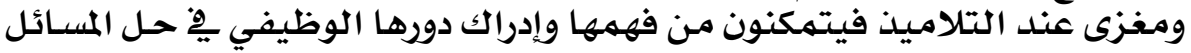

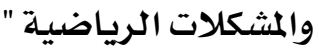

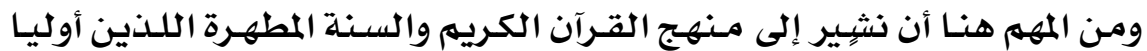

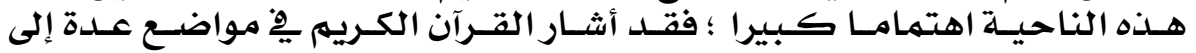

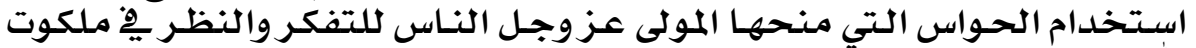

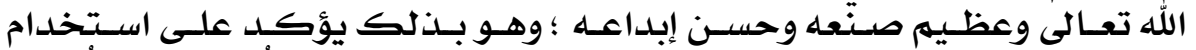

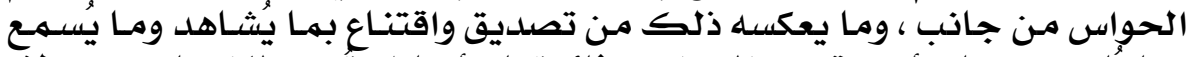

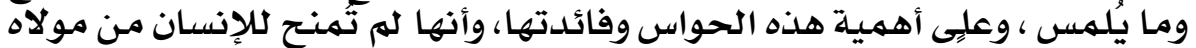

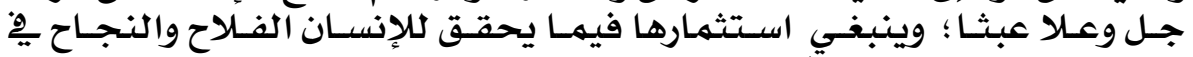

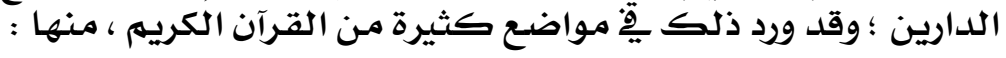

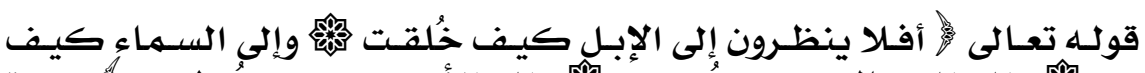

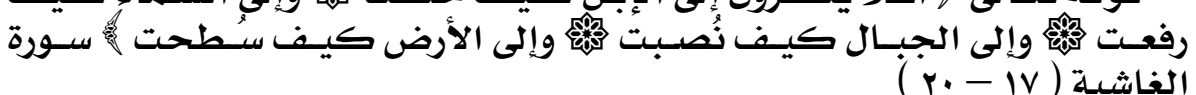

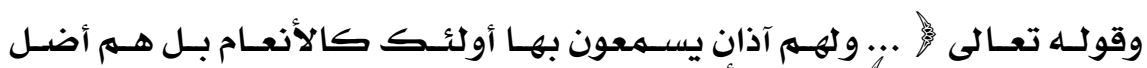

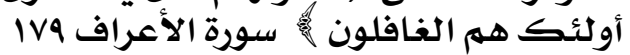

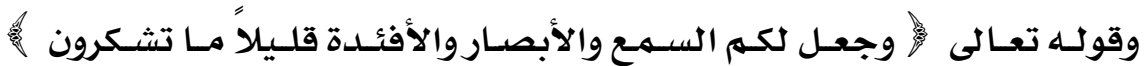

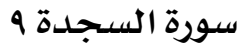

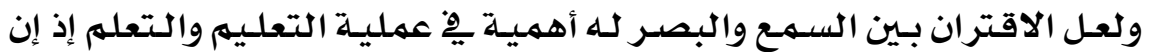

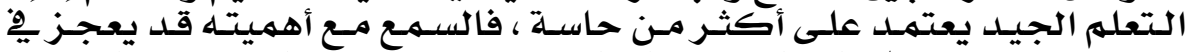

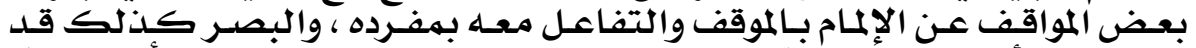

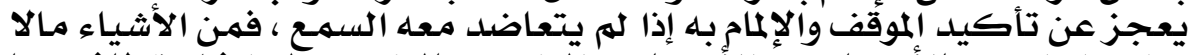

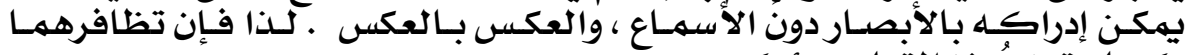

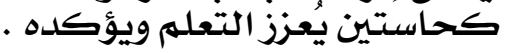

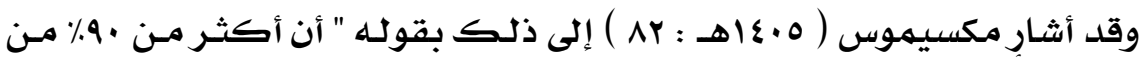

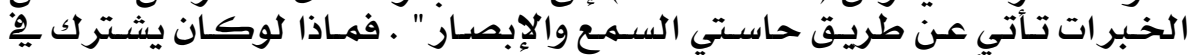

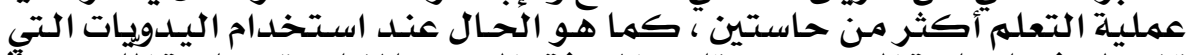

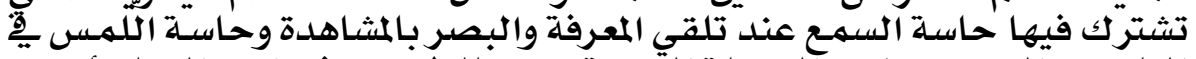

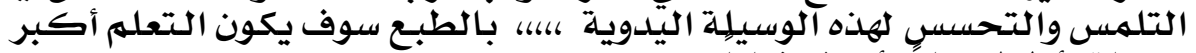

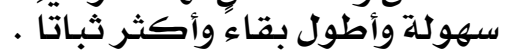

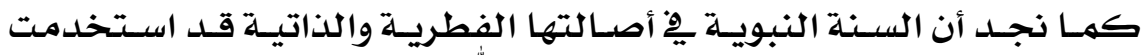

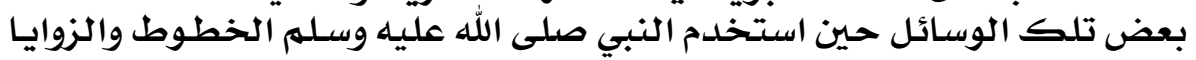

\section{Vo}




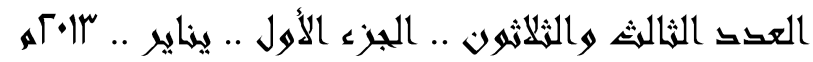

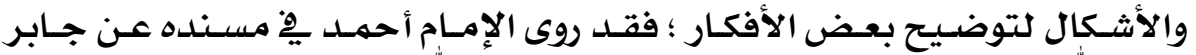

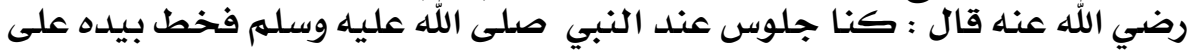

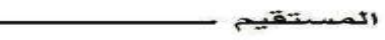

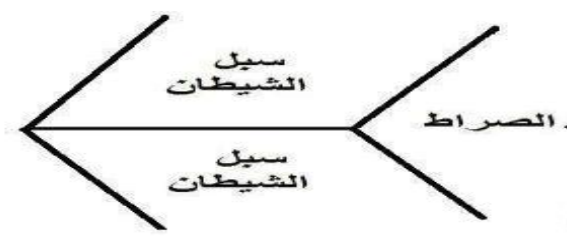

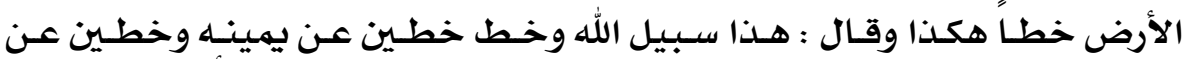

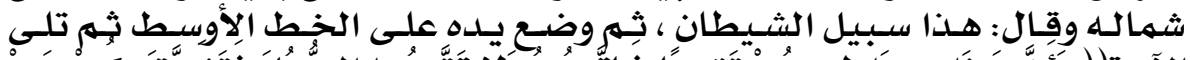

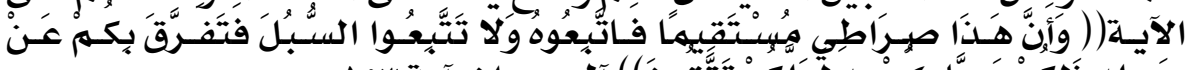

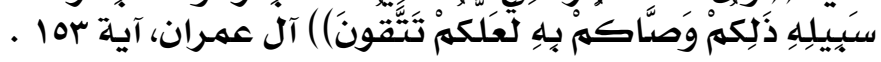

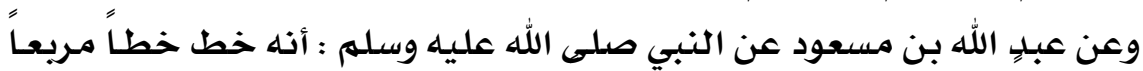

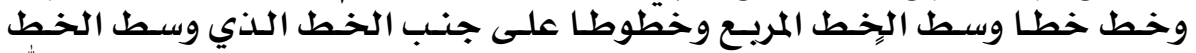

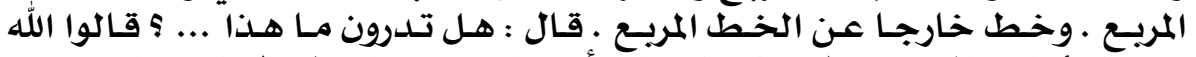

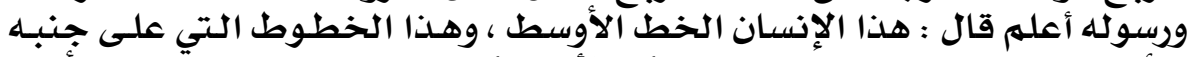

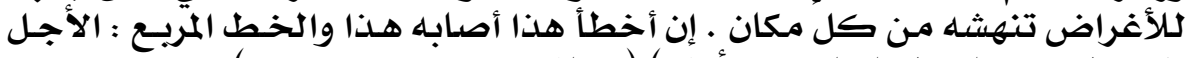

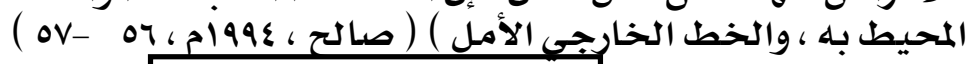

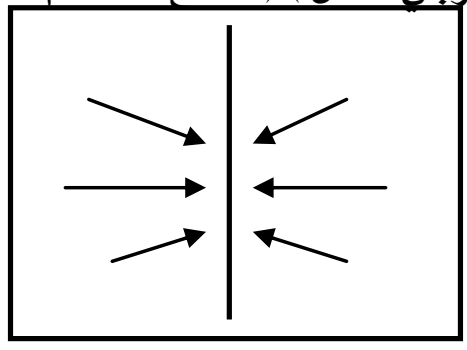

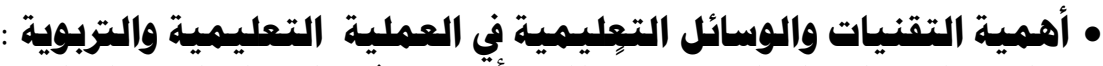

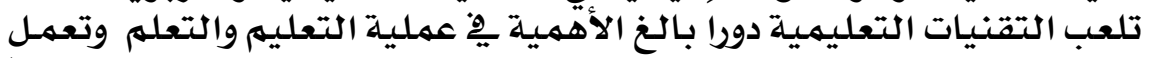

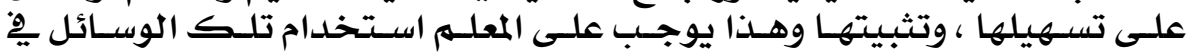

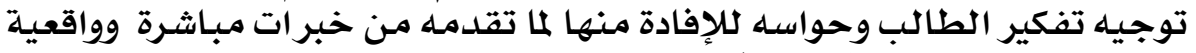

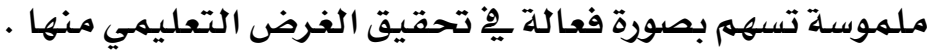

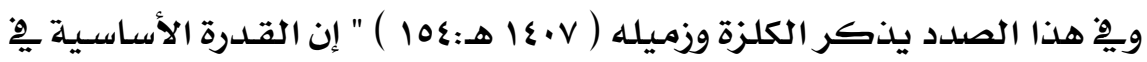

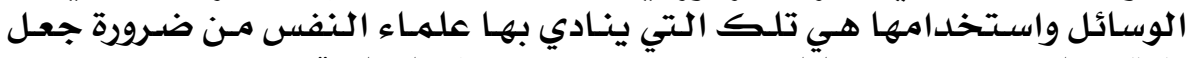

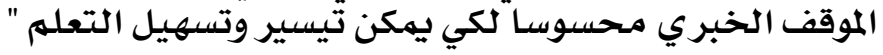

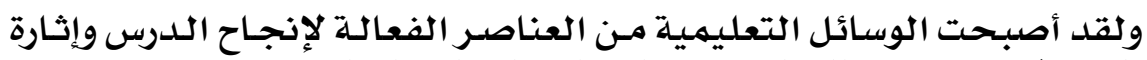

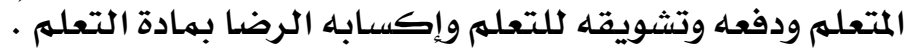

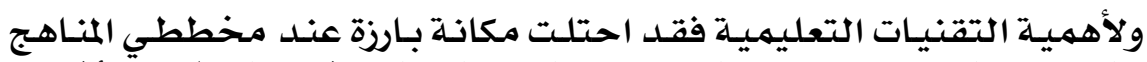

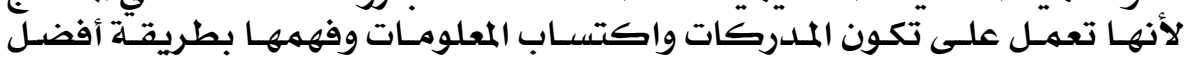

\section{$1 V 7$}




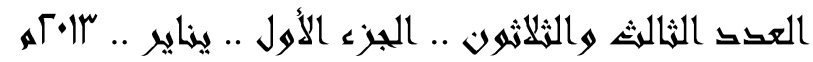

وأعمق لدى الطالب وتعمل على تشغيل حواسـه المختلفة وتكون اتجاهـات إيجابيـة لديه .

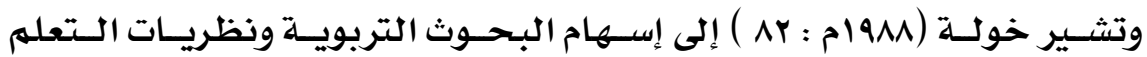

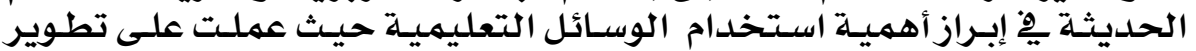

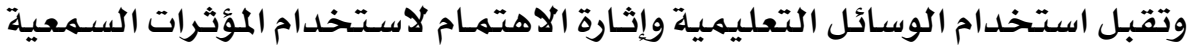

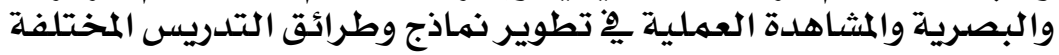

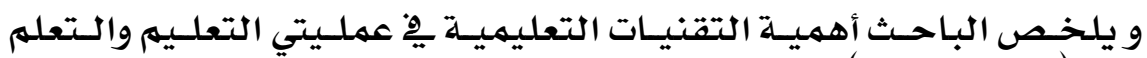

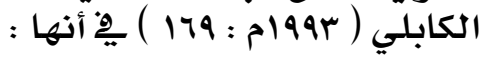

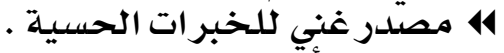

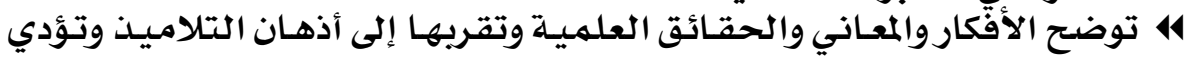

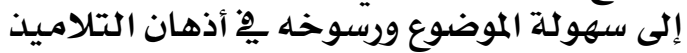

414 تجعل التعليه أبقى وأعمق ألمقئ أثرا.

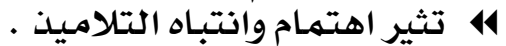

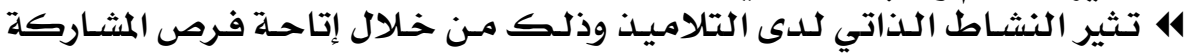

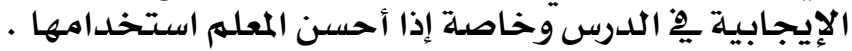

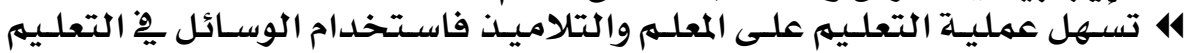

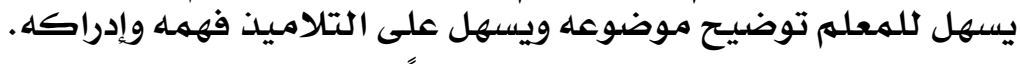

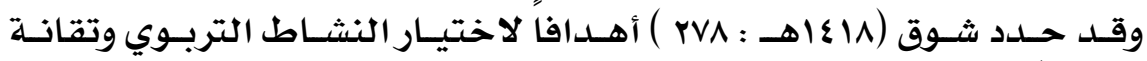

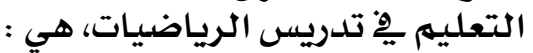

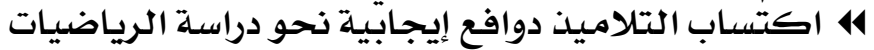

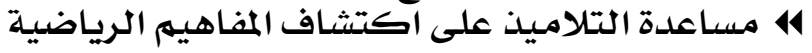

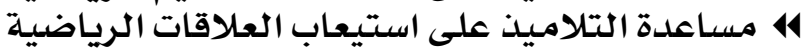

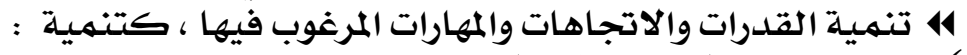

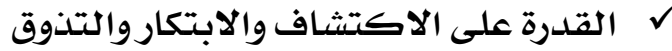

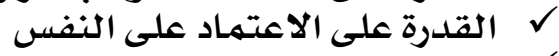
ل

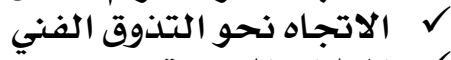

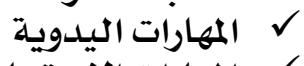

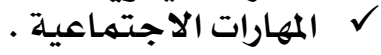

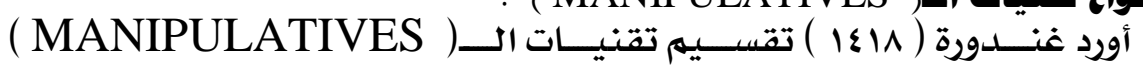

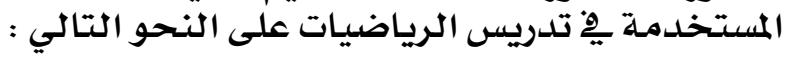

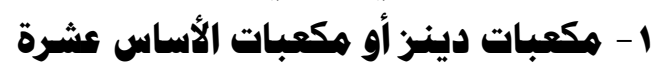

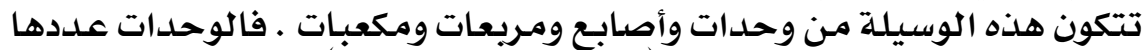

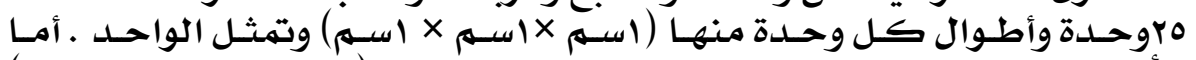

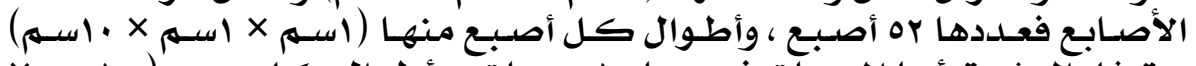

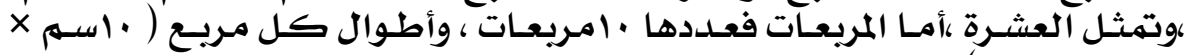

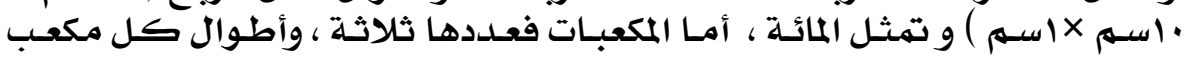

\section{IVV}

دوأسأت كربية في النتبية وعنم ألنفسي (ASEP) 


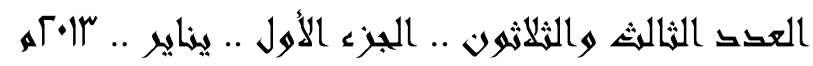

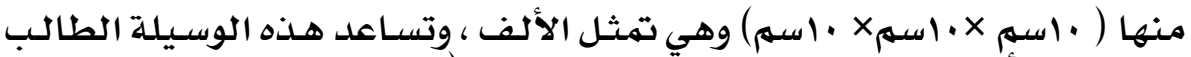

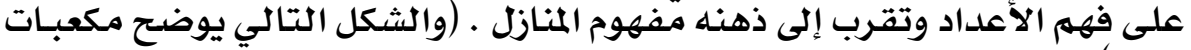
دينز ( )
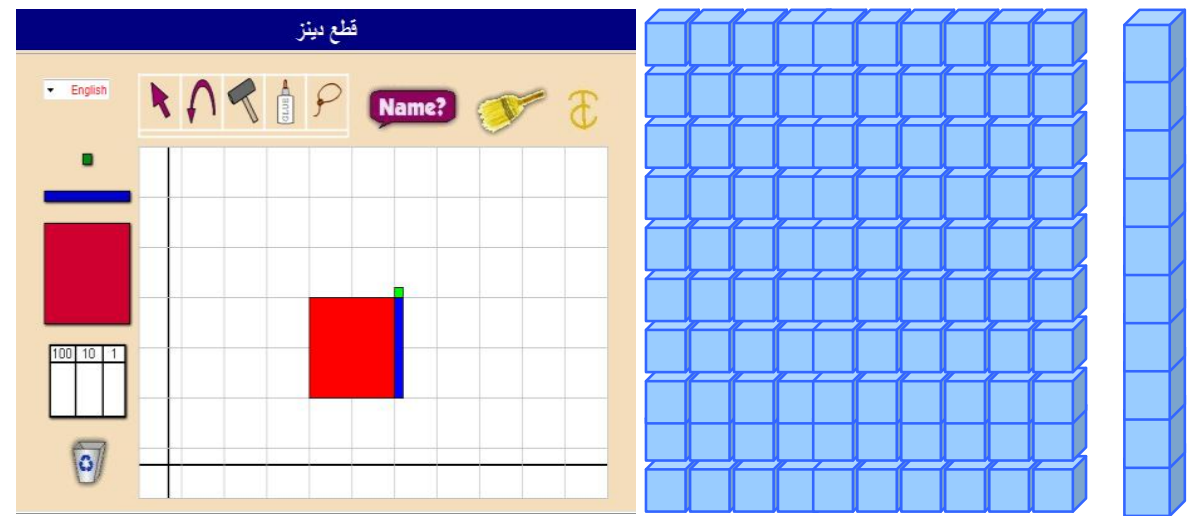

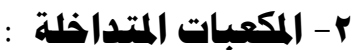

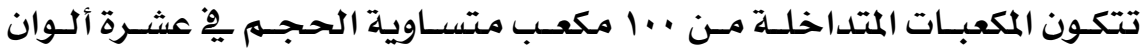

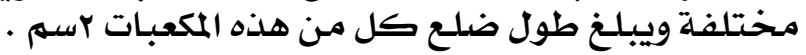
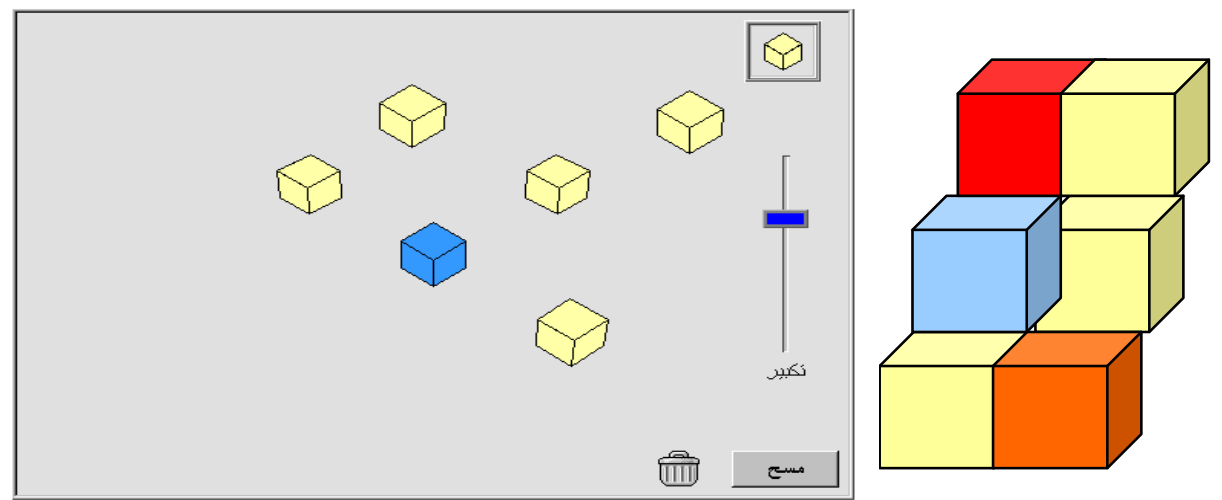

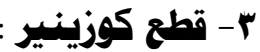

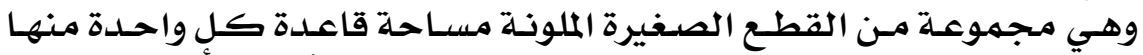

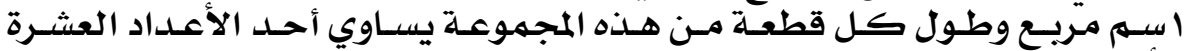

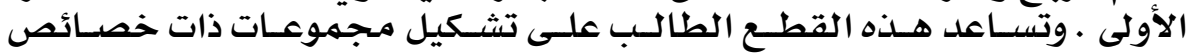

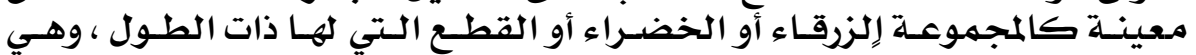

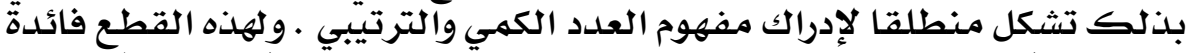

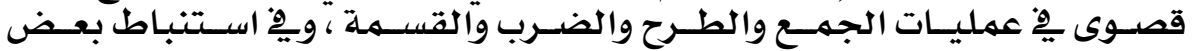

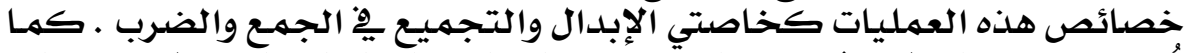

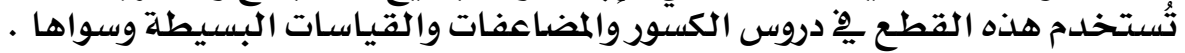

\section{$1 \vee \wedge$}




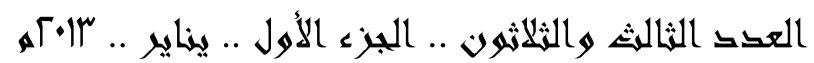
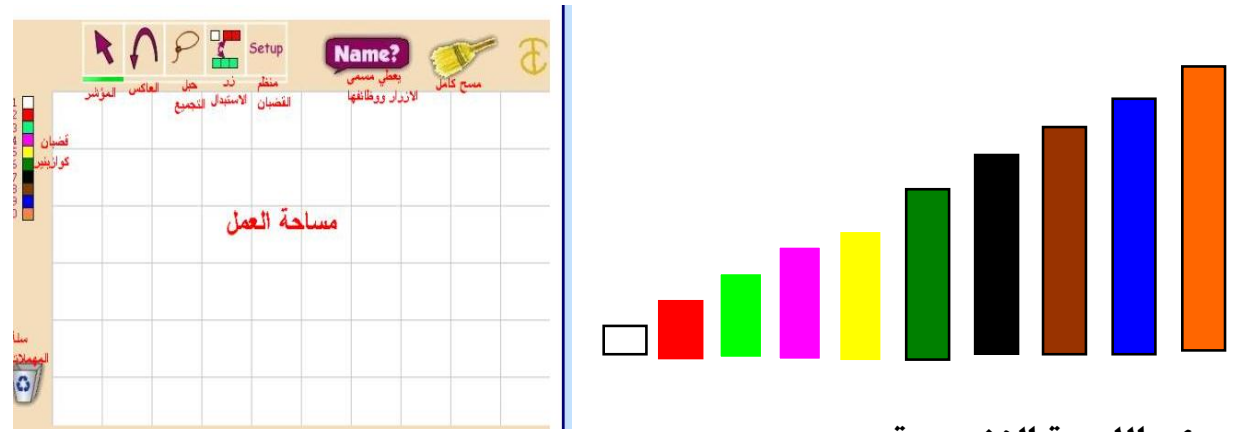

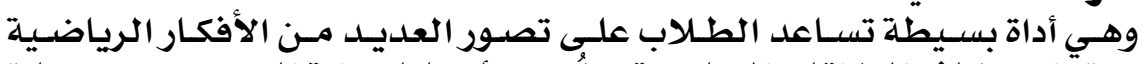

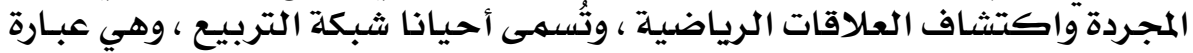

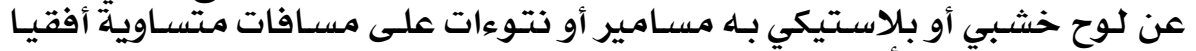

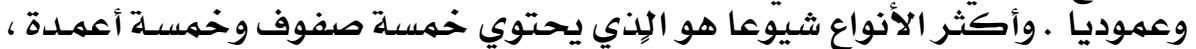

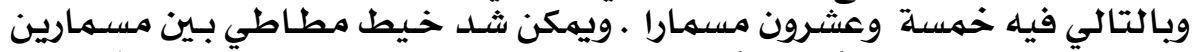

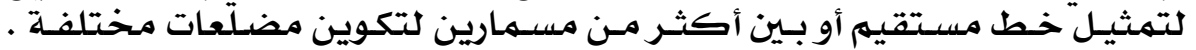

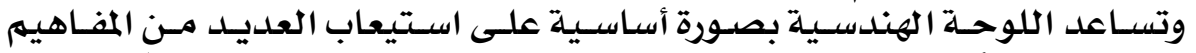

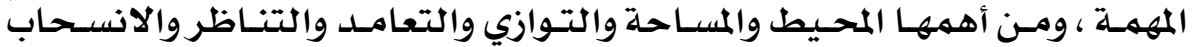

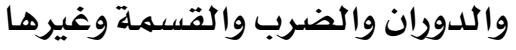
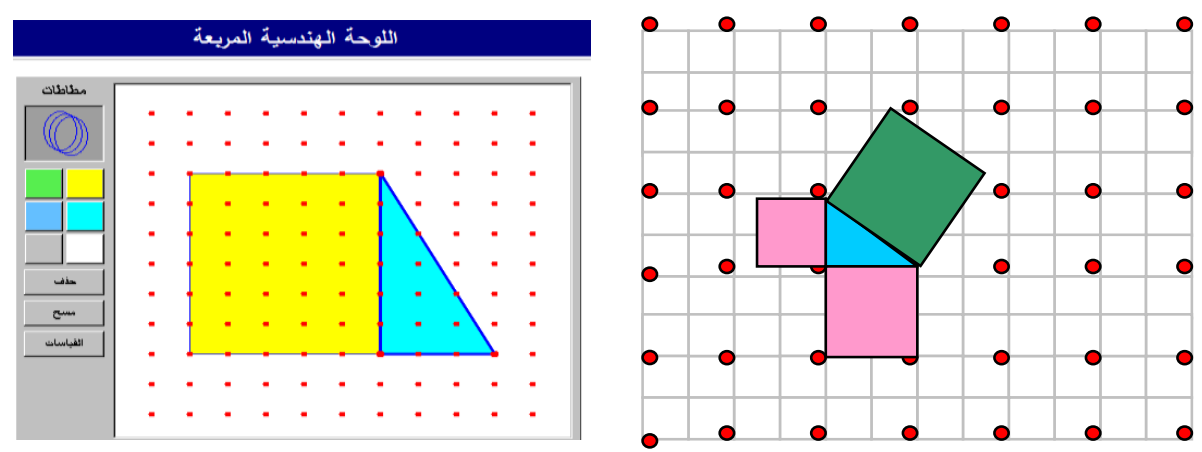

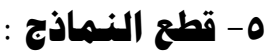

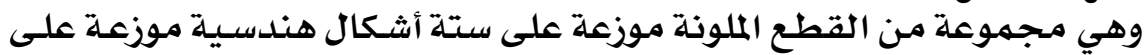

$$
\begin{aligned}
& \text { النحو آتتالي: هيو: }
\end{aligned}
$$

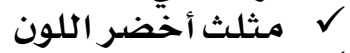

$$
\begin{aligned}
& \text { ل }
\end{aligned}
$$

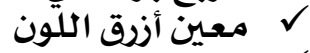

$$
\begin{aligned}
& \text { ل ل معين أبيض أندف اللون }
\end{aligned}
$$

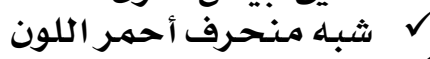

$$
\begin{aligned}
& \checkmark
\end{aligned}
$$

\section{$1 \vee 9$}




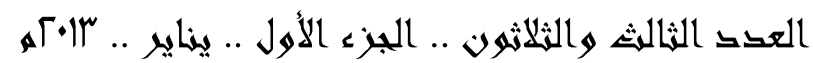

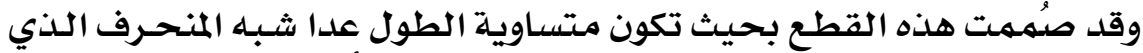

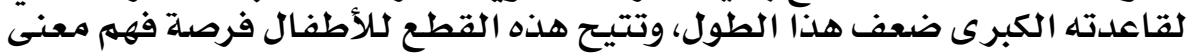

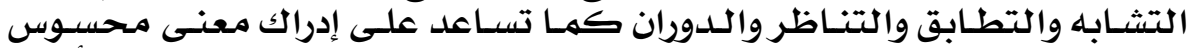

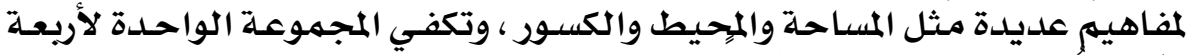

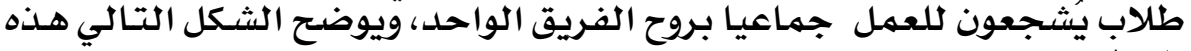

\section{قطب النمادّج}
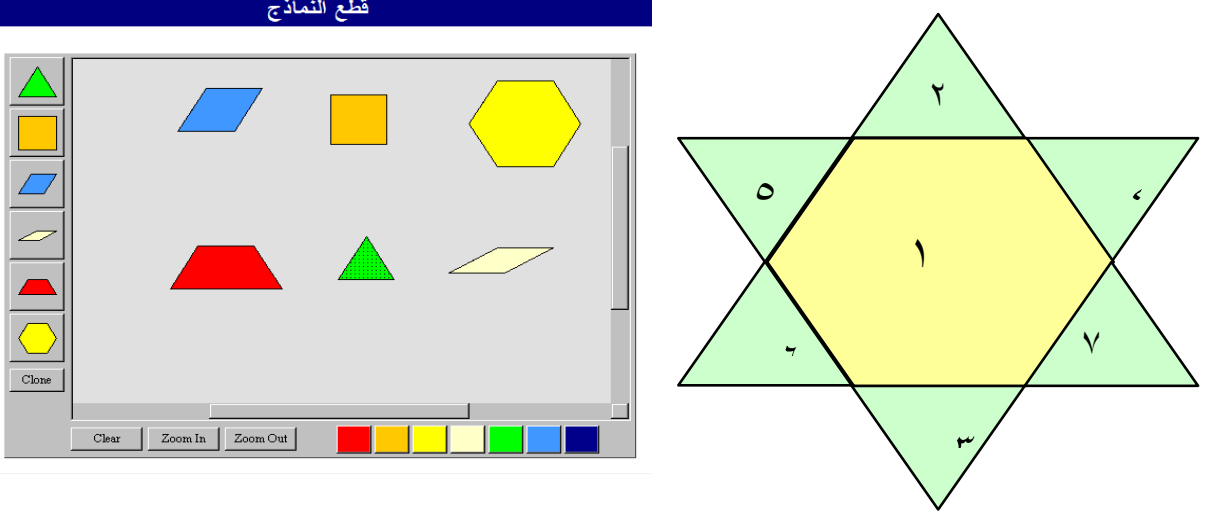

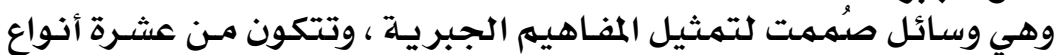

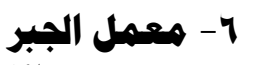

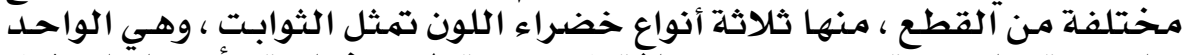

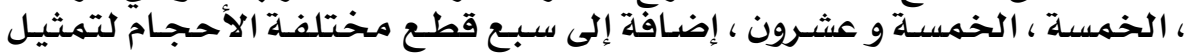

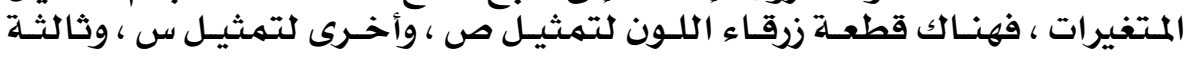

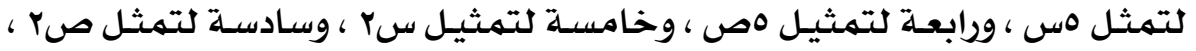

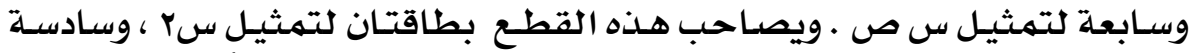

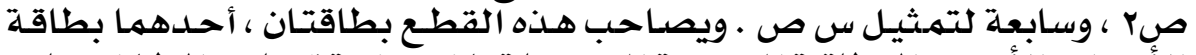

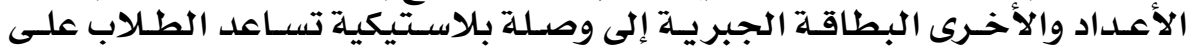

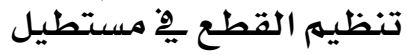

\section{مeمل الجير}
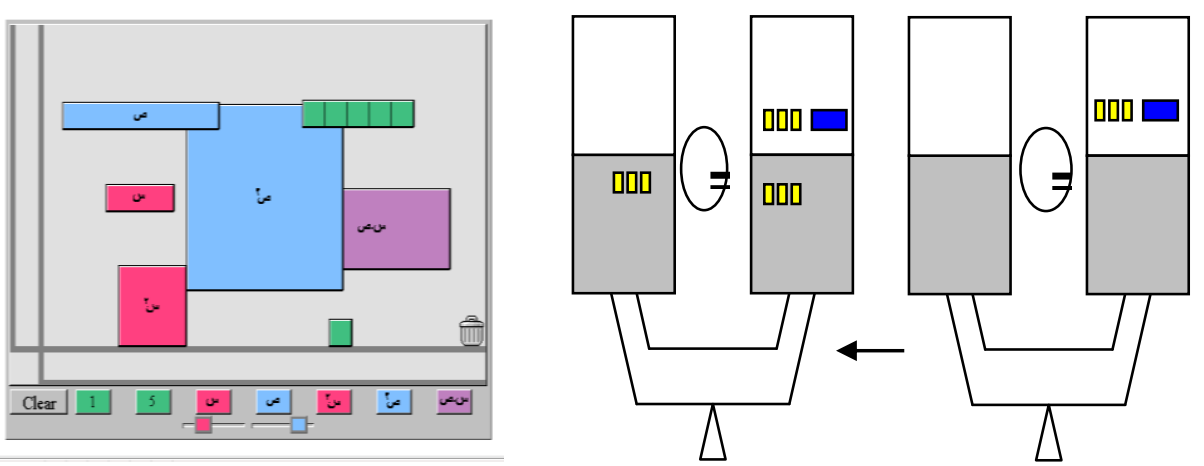

\section{$1 \wedge$}




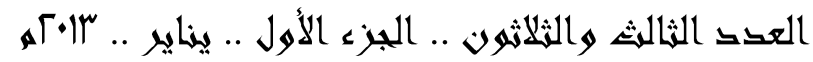

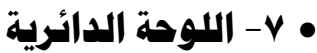

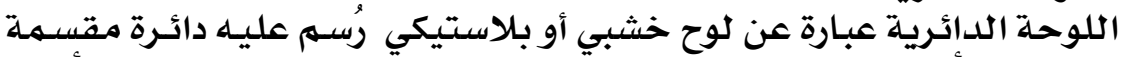

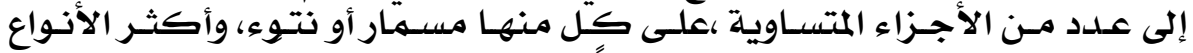

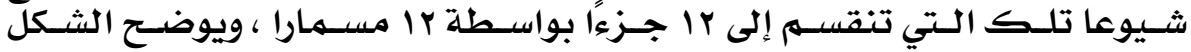

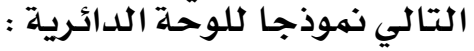
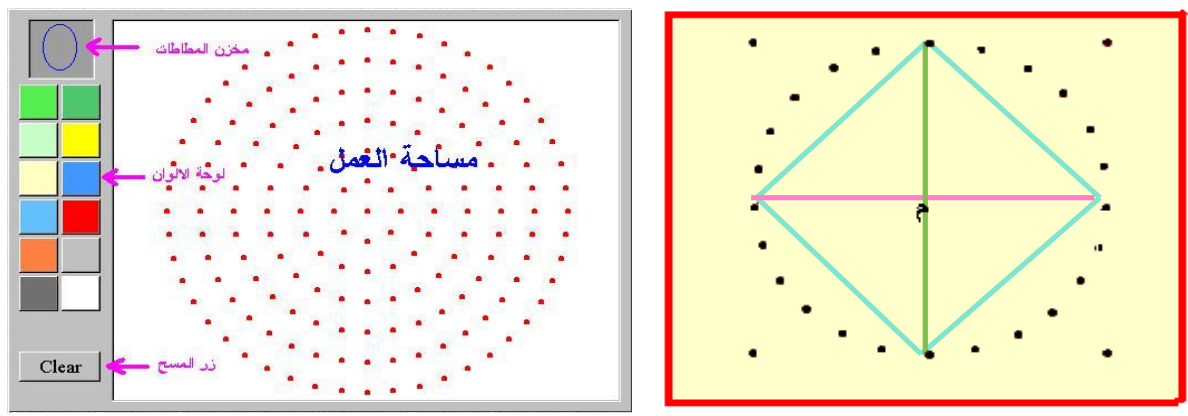

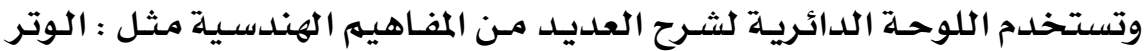

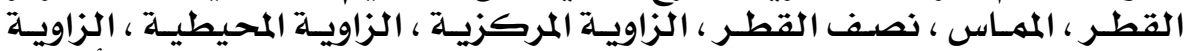

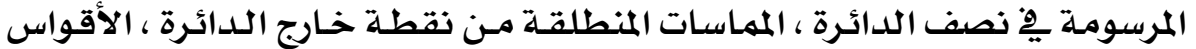

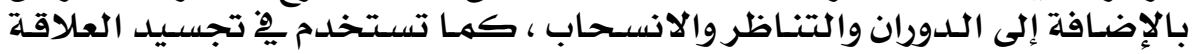

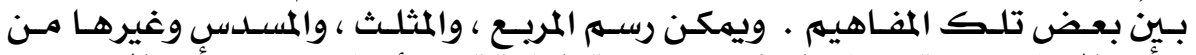

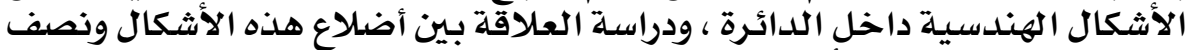

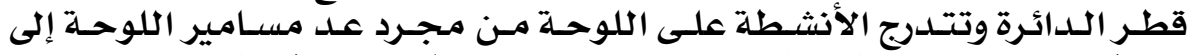

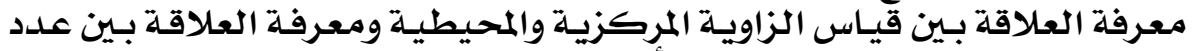

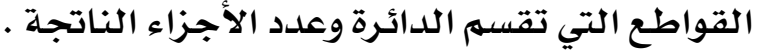

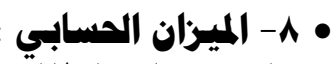

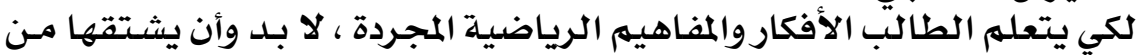

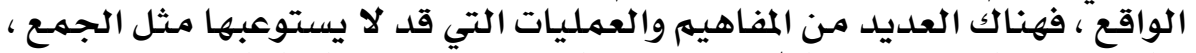

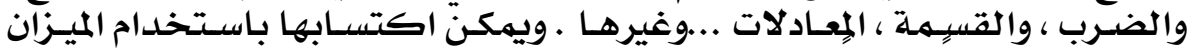

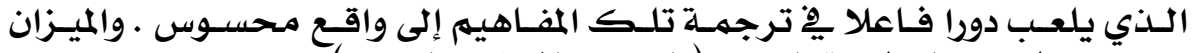

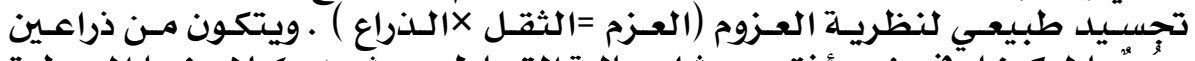

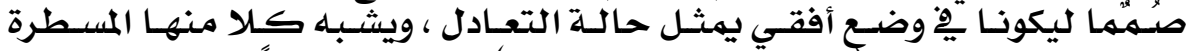

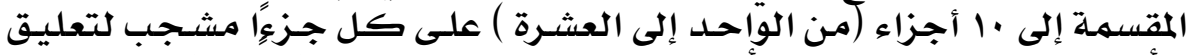

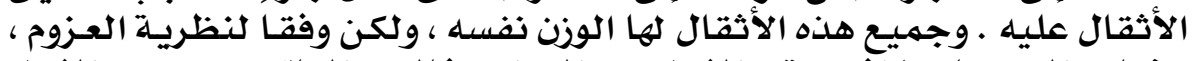

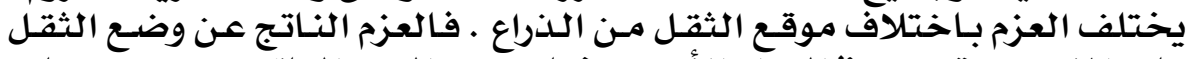

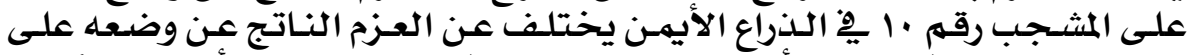

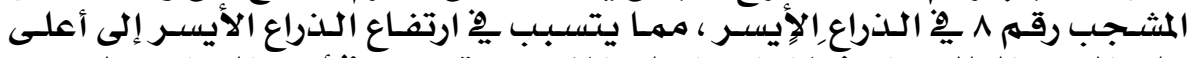

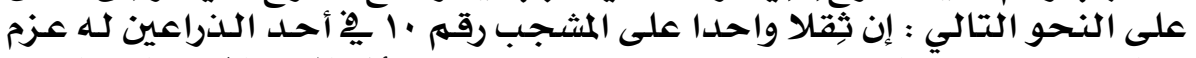

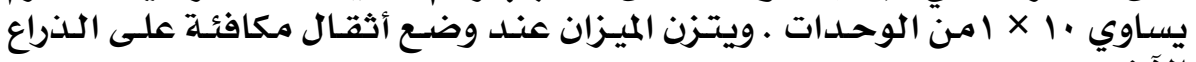




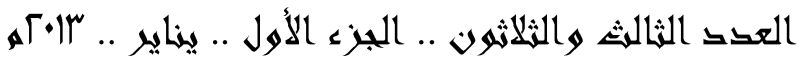

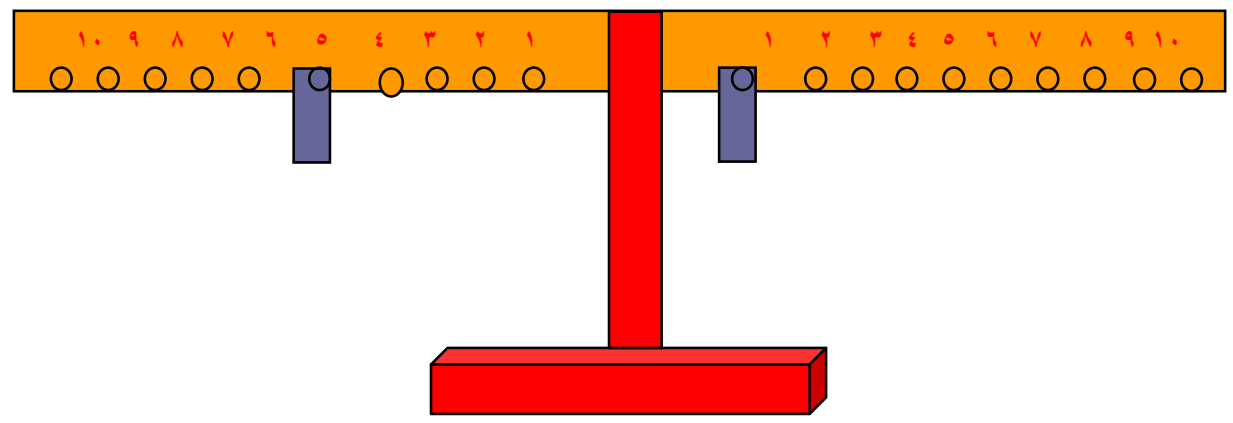

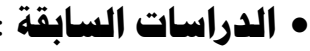

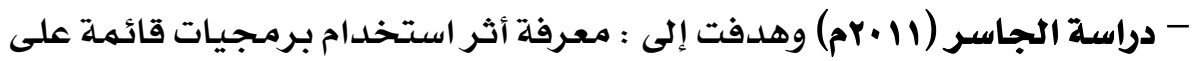

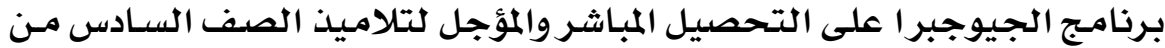

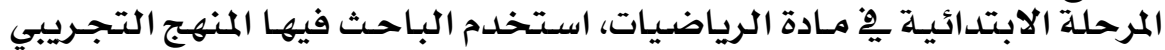

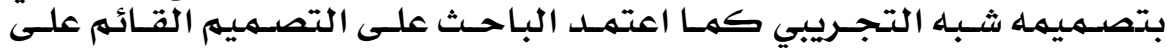

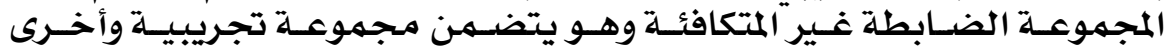

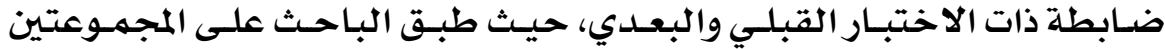

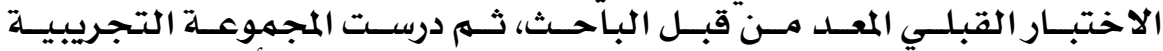

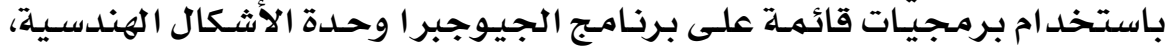

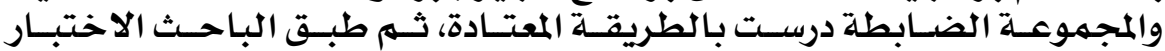

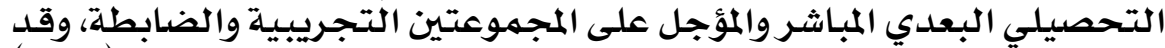

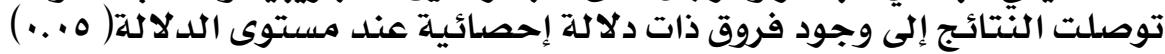

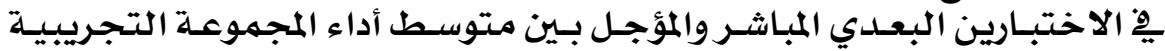

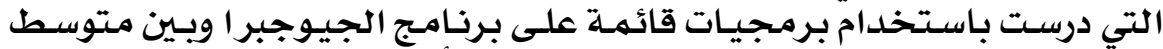

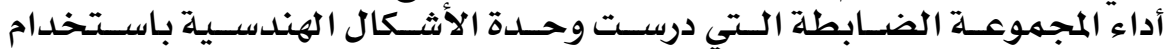

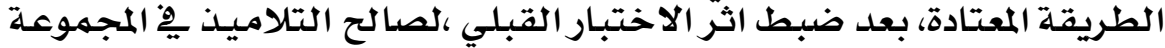
التجريبية.

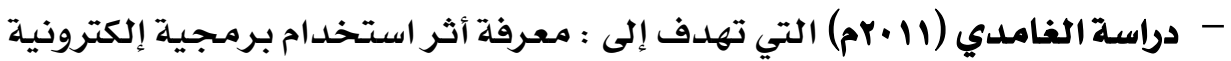

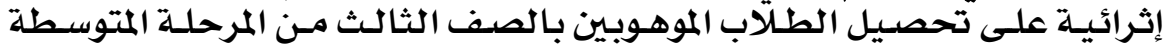

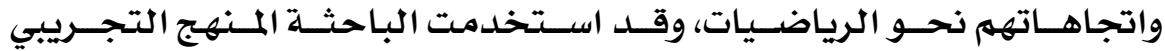

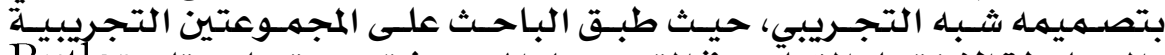

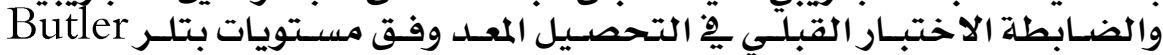

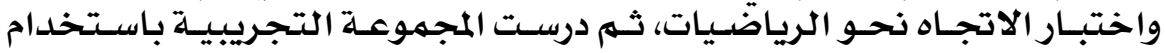

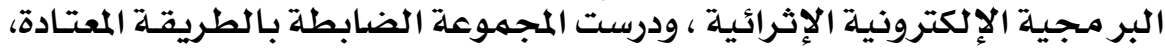

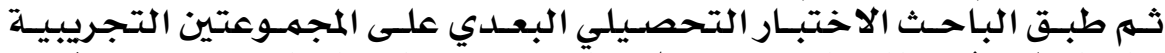

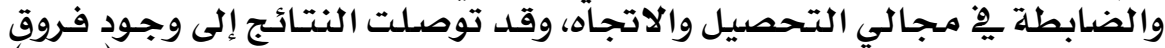

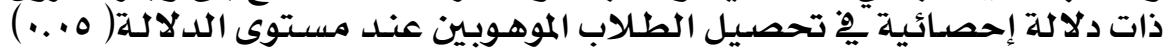

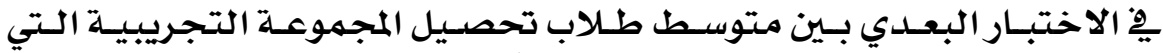

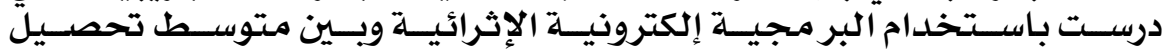

\section{$1 \wedge Y$}




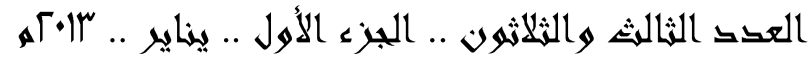

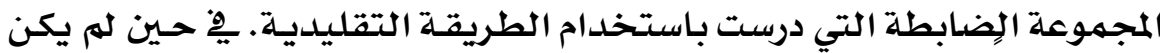

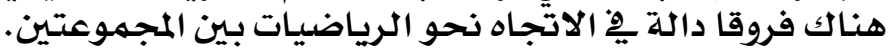

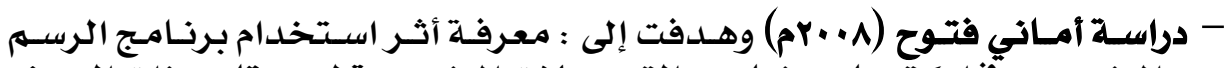

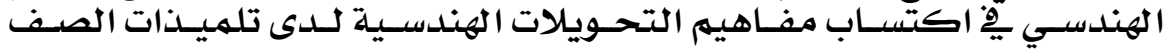

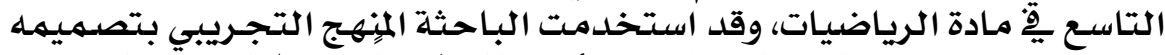

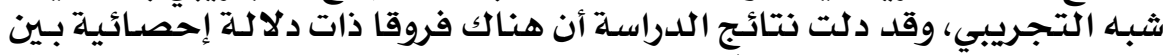

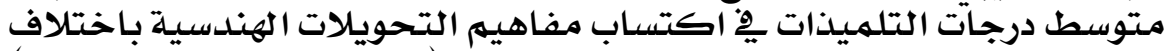

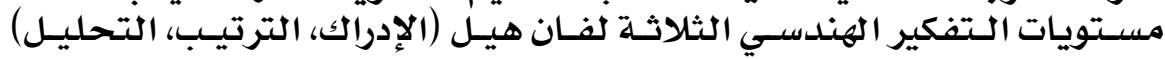

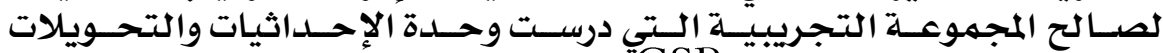

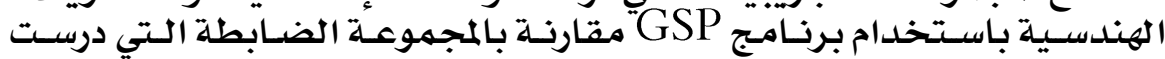

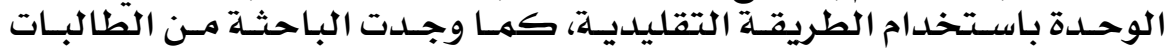

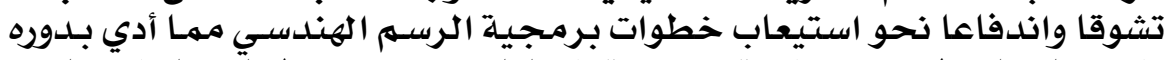

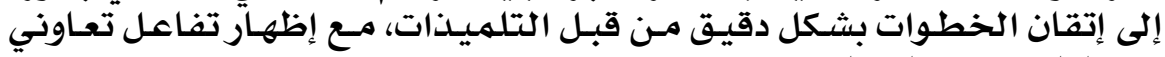

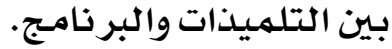

- دراسة والكرو زيدلر 2003) -

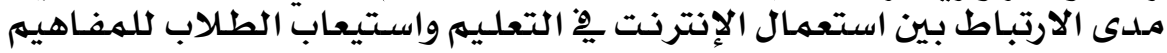

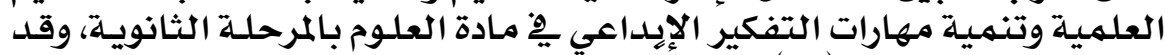

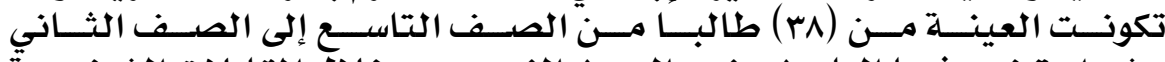

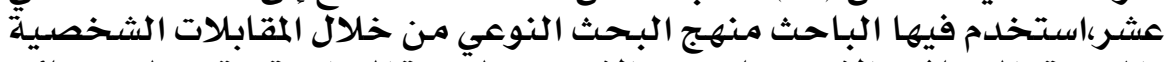

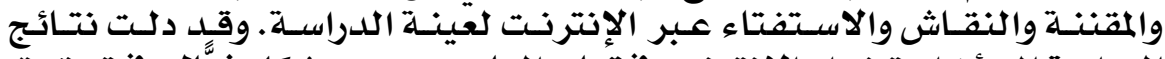

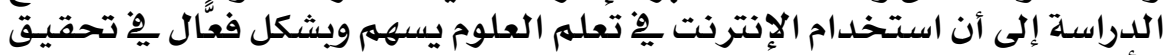

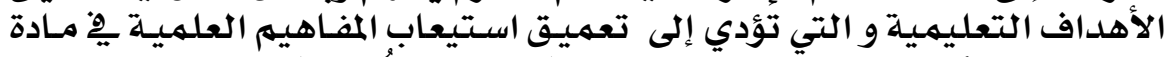

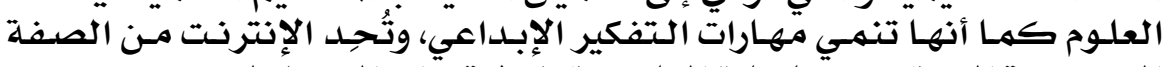

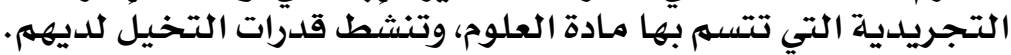

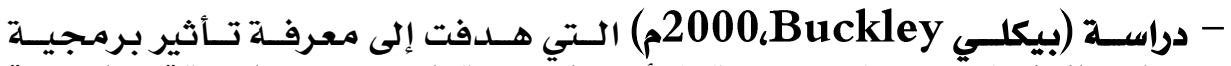

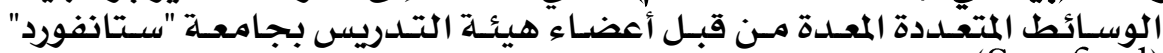

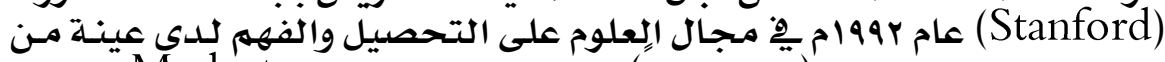

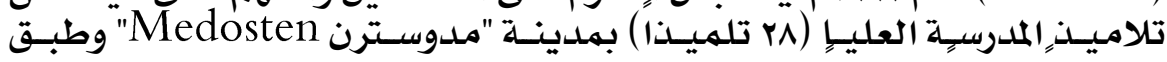

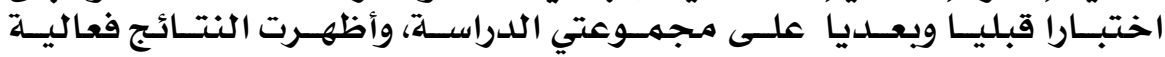

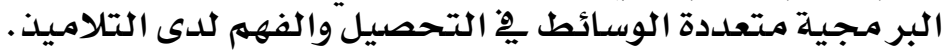

- دراسة (ويتكنز Watkins،

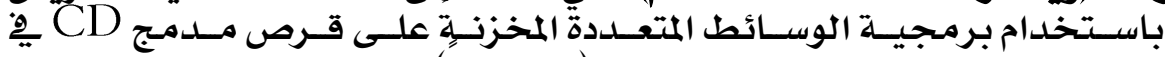

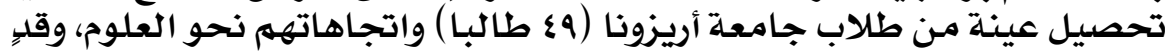

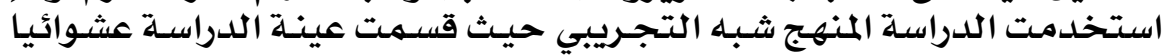

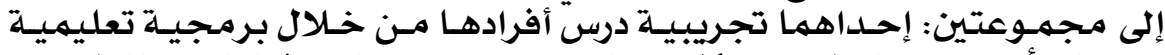

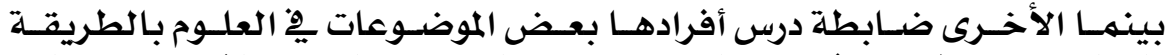

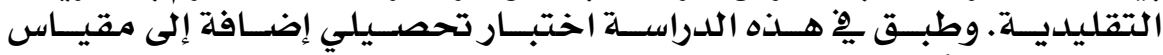

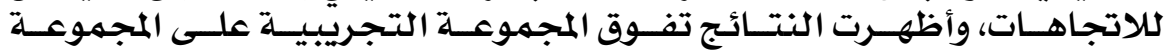

\section{$1 \wedge r$}




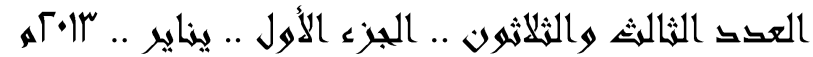

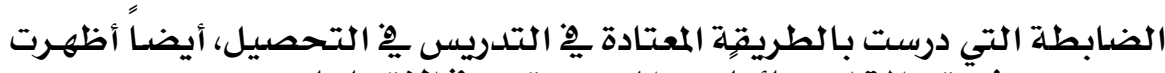

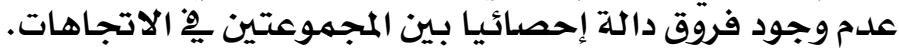

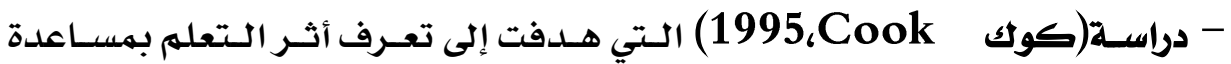

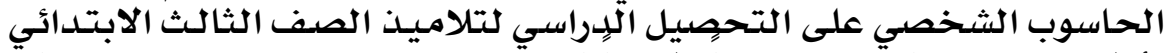

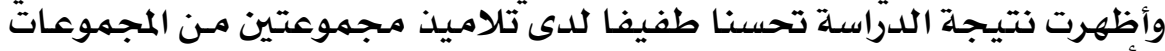

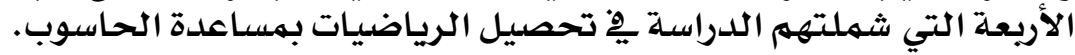

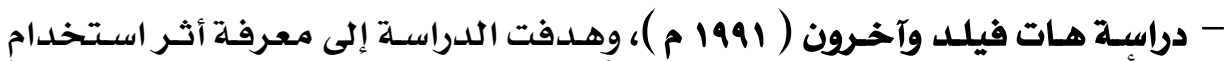

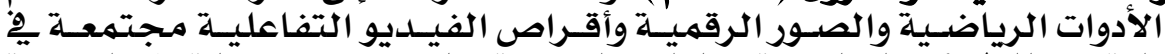

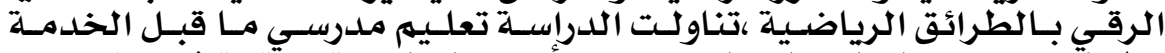

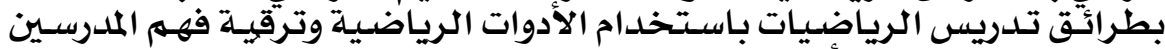

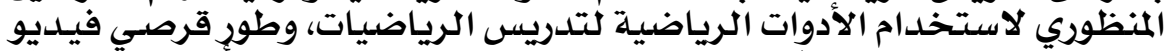

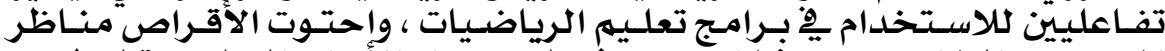

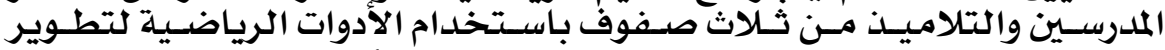

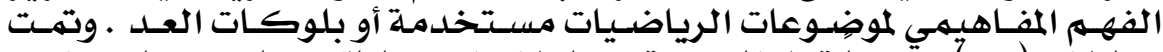

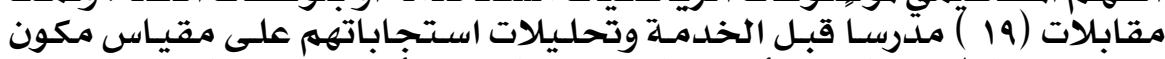

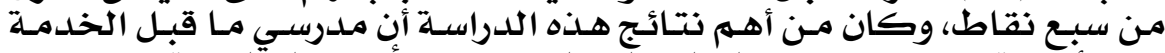

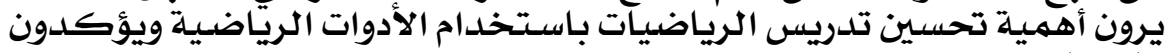
على ذلك.

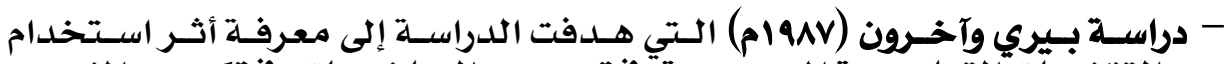

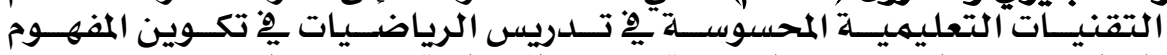

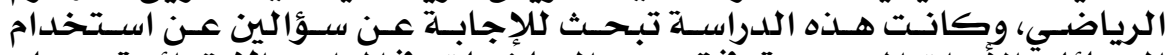

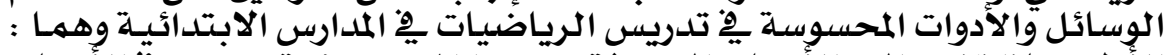

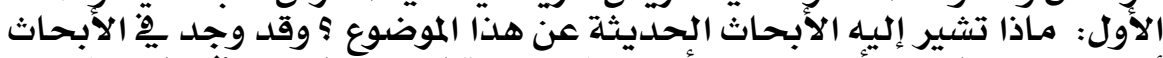

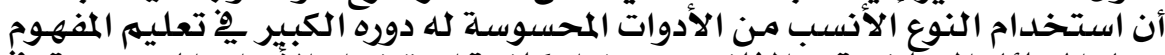

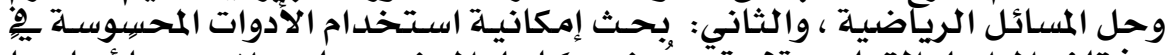

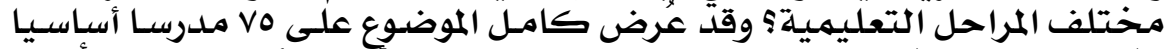

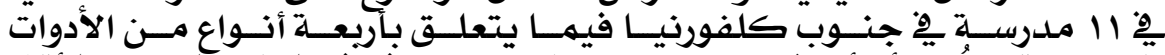

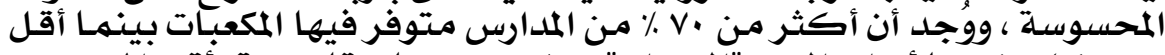

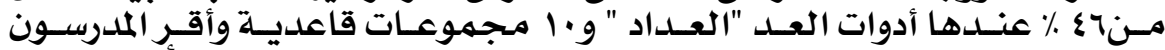

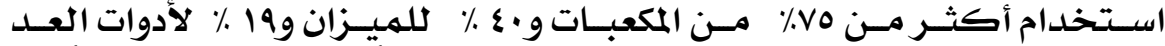

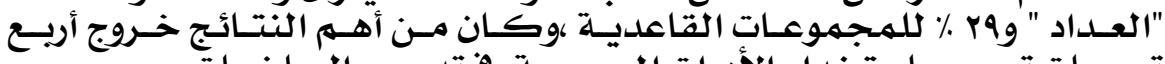

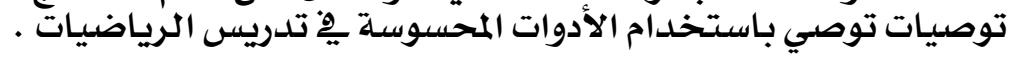

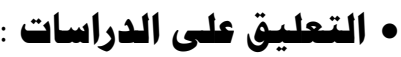

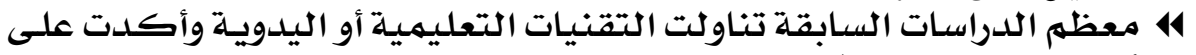

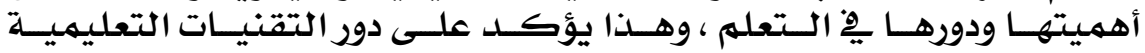

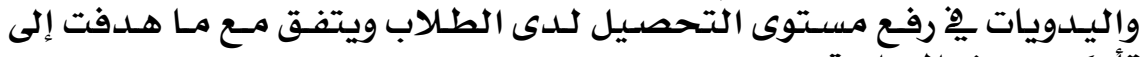

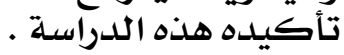

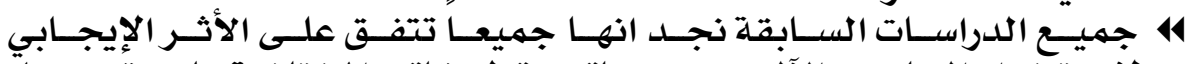

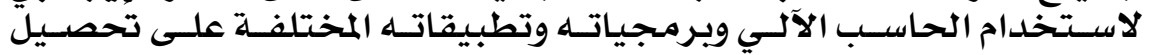

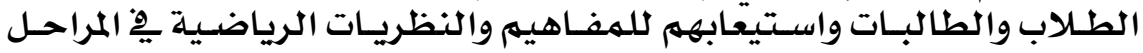

\section{$1 \wedge \varepsilon$}




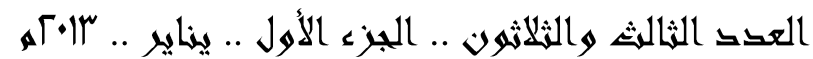

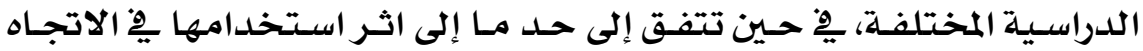
الإيجابي نحو الرياضياضيات.

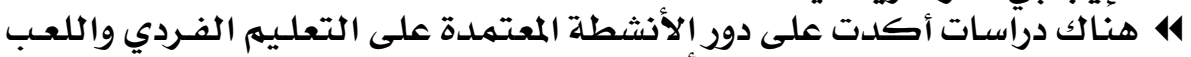

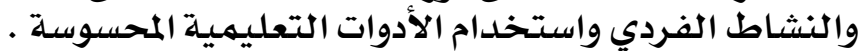

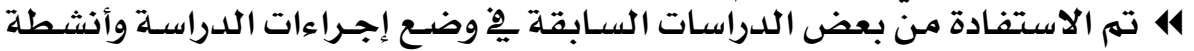
العمل دالاستف

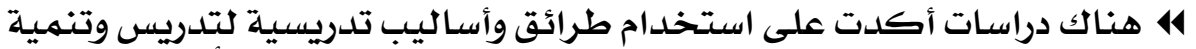

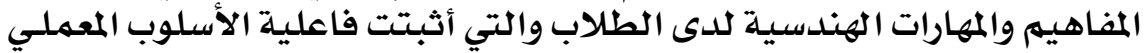

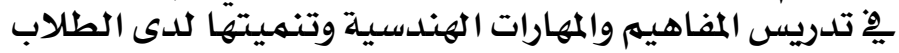

\section{• منهمية الدراسة وإجراء|تها}

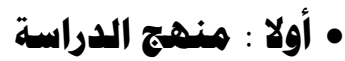

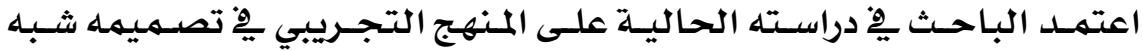

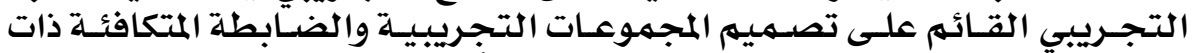

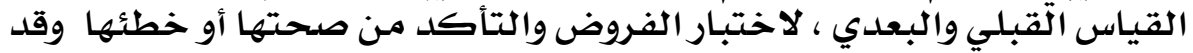

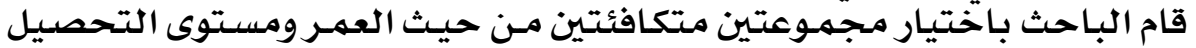

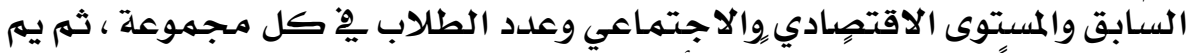

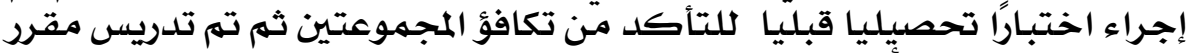

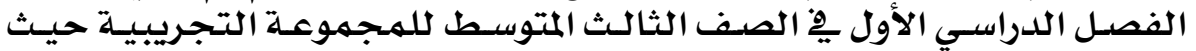

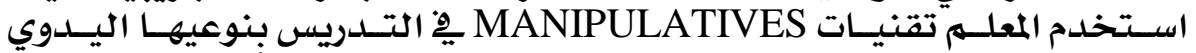

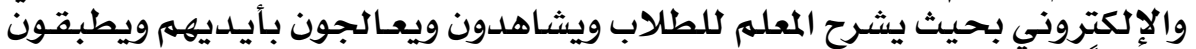

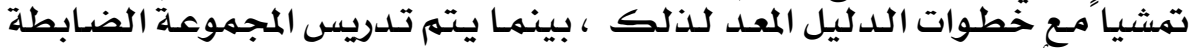

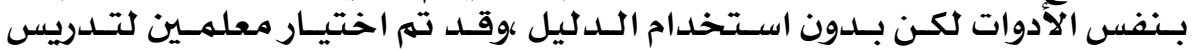

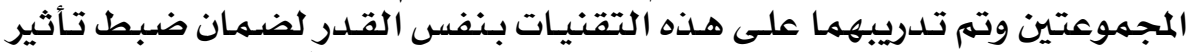

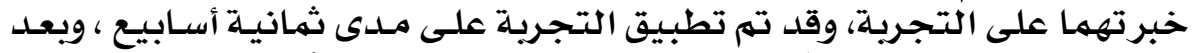

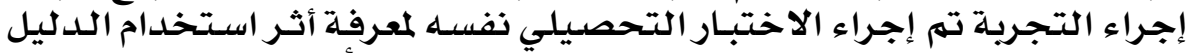

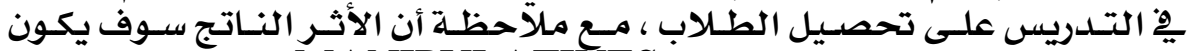

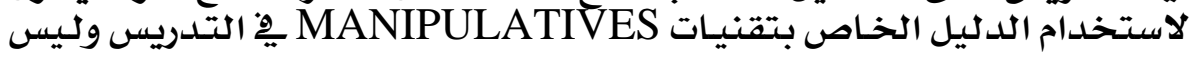

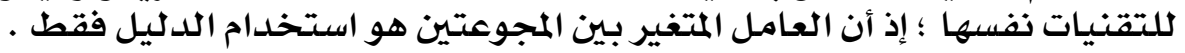

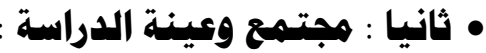

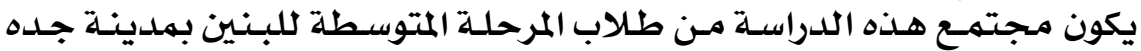

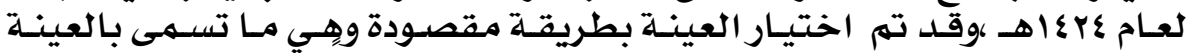

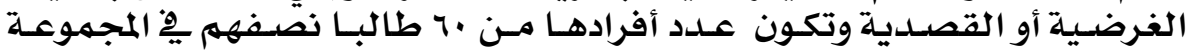

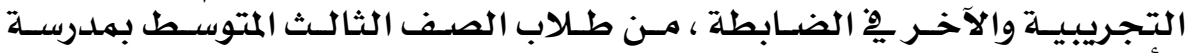

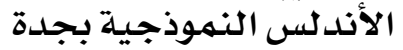

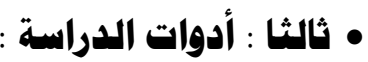

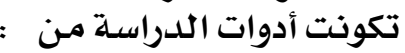

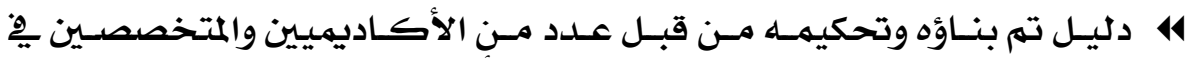

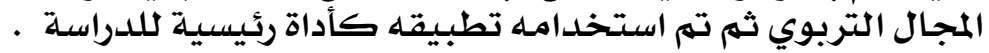

\section{$1 \wedge \odot$}




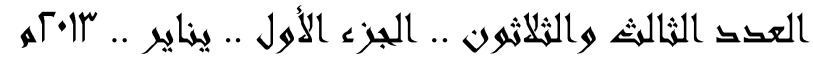

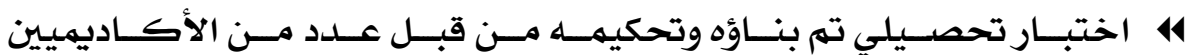

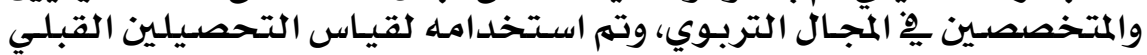

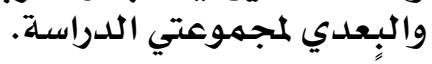

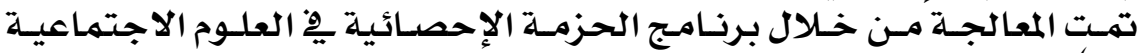

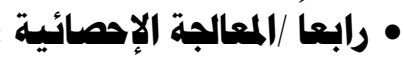

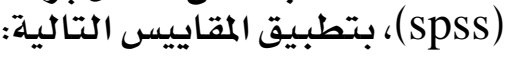

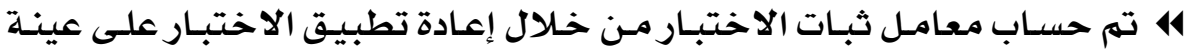

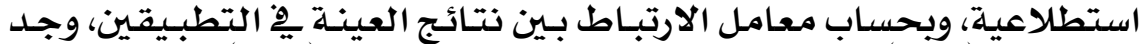

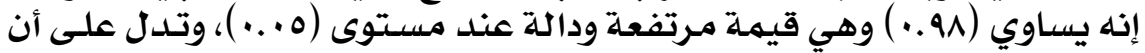

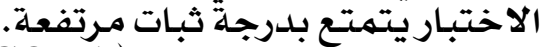

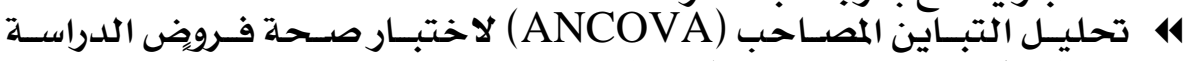
ولمعرفة دلالة هذه الفروق ، بالإضافة إلى ضبط المتلغيرات إحصائيا.

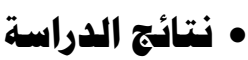

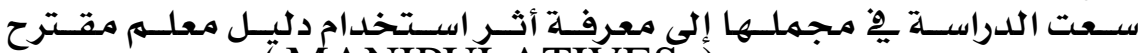

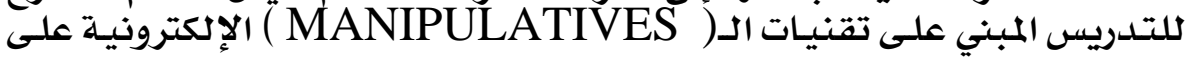

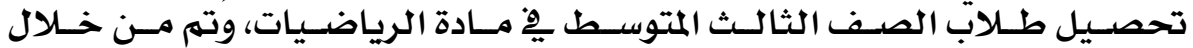

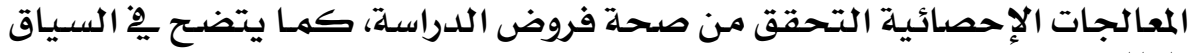
التالي:

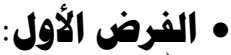

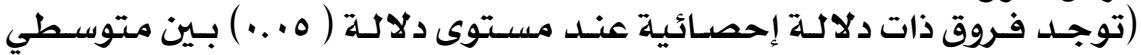

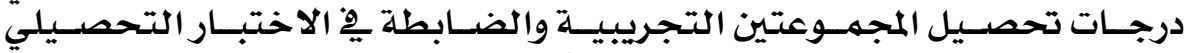

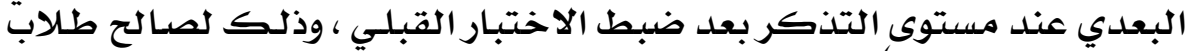

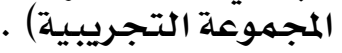

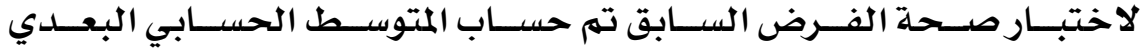

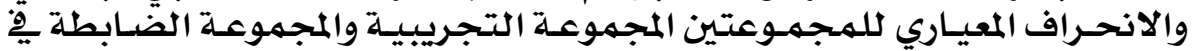

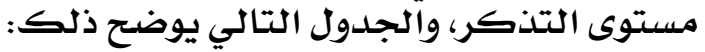

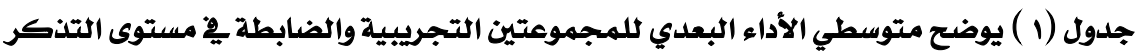

\begin{tabular}{|c|c|c|c|}
\hline \multicolumn{2}{|c|}{ المجموعة الضابطة } & \multicolumn{2}{|c|}{ المجموعة التجريبية } \\
\hline الانحراف المعياري & المتوسط الحسابى & الانحراف المعياري & المتوسط الحسابي \\
\hline 3.08 & 5.32 & 2.64 & 8.41 \\
\hline
\end{tabular}

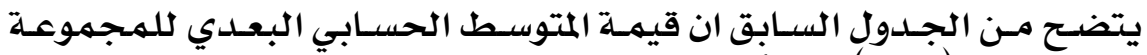

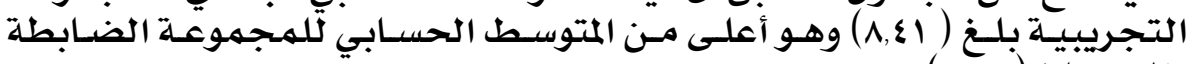

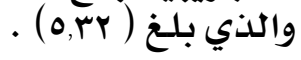

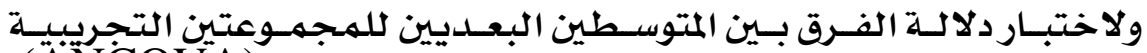

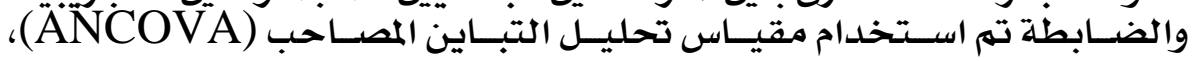

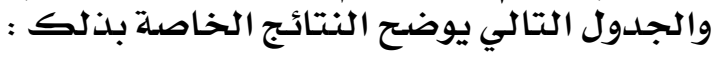

\section{$1 \wedge 7$}




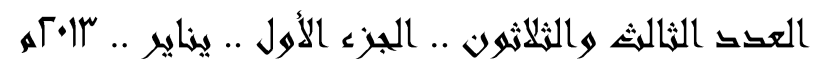

جلدول (Y) : يوضح تحليل التباين المصاحب لقياسات المجموعتين التجريبية والضابطة ـِ2 مستوى

\begin{tabular}{|c|c|c|c|c|c|}
\hline \multicolumn{6}{|c|}{ التذذكر } \\
\hline الدلالة & قيمـة "ف" & مترسط المربعات & الحرجية & مجربعات & مصدر التبـاين \\
\hline 0.210 & 1.623 & 0.567 & 1 & 0.567 & (الاتخير المصبار القبلي ) \\
\hline 0000 & *23.544 & 8.225 & 1 & 8.225 & العامل التجـريبي المجموعات) \\
\hline & & 0.349 & 61 & 13.624 & الخجماً ( داخل ) الخمات ) \\
\hline & & & 60 & 21.905 & المجموع المصحح \\
\hline
\end{tabular}

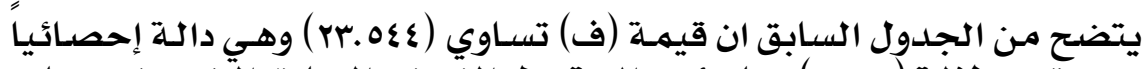

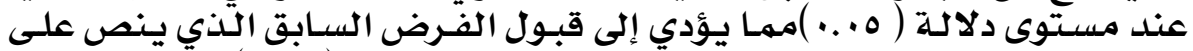

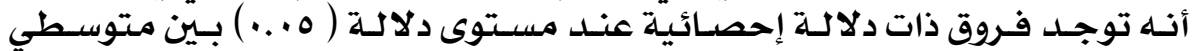

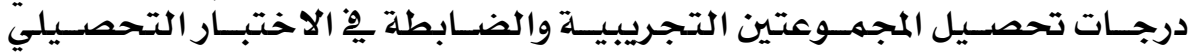

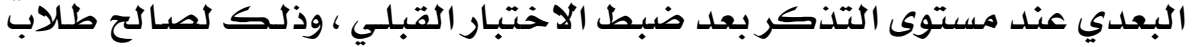

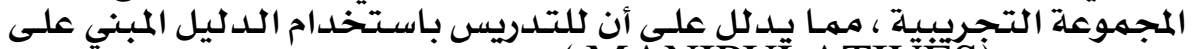

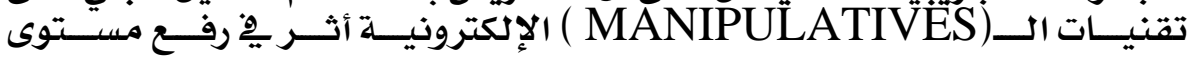

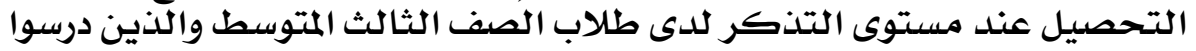

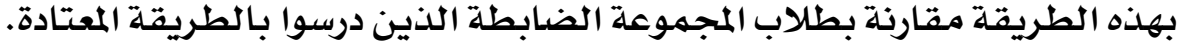

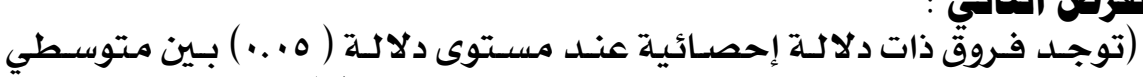

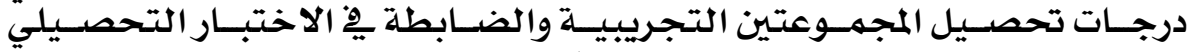

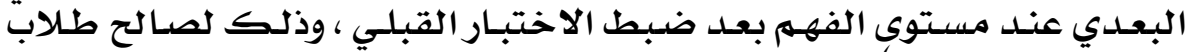

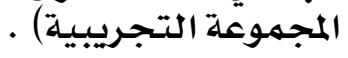

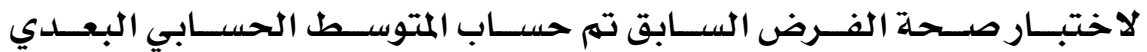

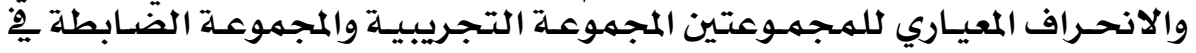

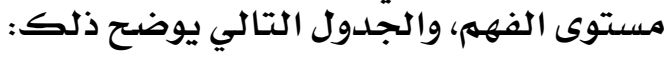

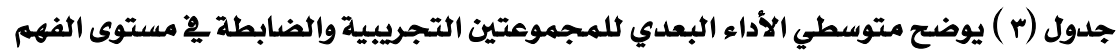

\begin{tabular}{|c|c|c|c|}
\hline \multicolumn{2}{|c|}{ المجموعة الضابطة } & \multicolumn{2}{|c|}{ المجموعة التجريبية } \\
\hline الانحراف المعيـارى & المتوسط الحسـابى & الانحراف المعيـارى & المتوسط الحسـابي \\
\hline 3.08 & 5.69 & 2.64 & 7.23 \\
\hline
\end{tabular}

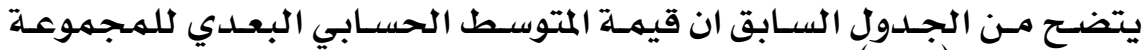

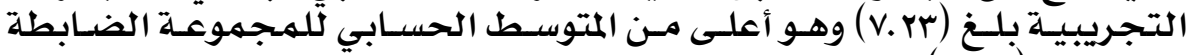
والذي بلّغ (

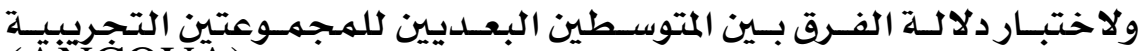

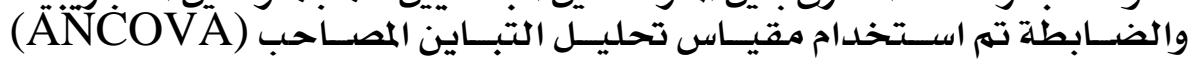

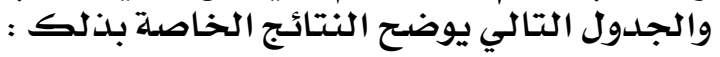

\section{IAV}

دوراسيات كربية في اليتربية وعثي النفضي (ASEP) 


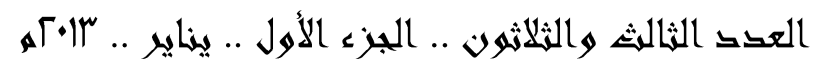

جدول (๕) : يوضح تحليل التباين المصاحب لقياسات المجموعتين التجريبية والضابطة فِ مستوى

\begin{tabular}{|c|c|c|c|c|c|}
\hline \multicolumn{6}{|c|}{ الفهرم } \\
\hline الدلادة & قيمـة "ف" & مترسطات & الحرجـة & مارجمبوت & مصدر التباين \\
\hline 0.067 & 3.538 & 1.133 & 1 & 1.133 & التقبلير المصاحب (الاختبار \\
\hline 0000 & $* 51.023$ & 16.336 & 1 & 16.336 & العامل التجريبي ( بين \\
\hline & & 0.320 & 61 & 11.02 & الخطأ ( داخل المجموعات ) \\
\hline & & & 60 & 30.900 & المجموع المصحح \\
\hline
\end{tabular}

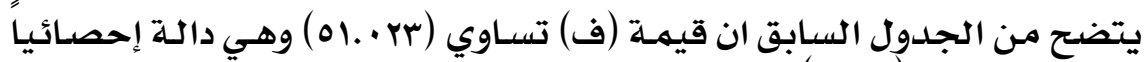

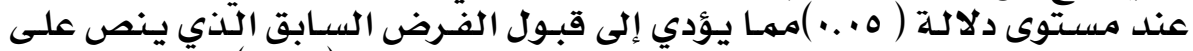

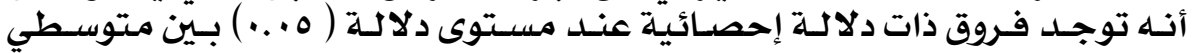

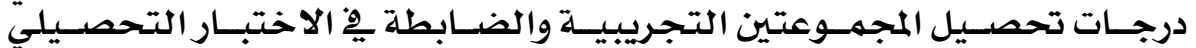

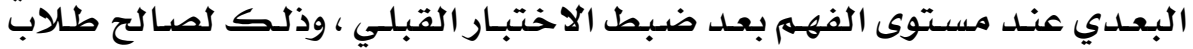

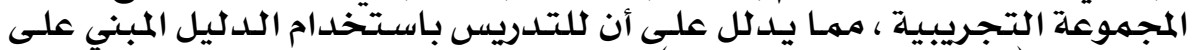

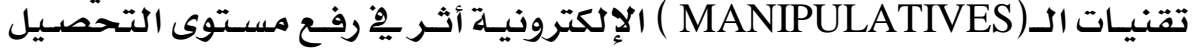

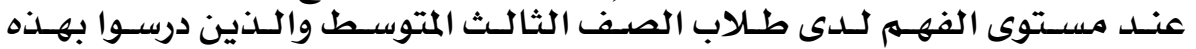

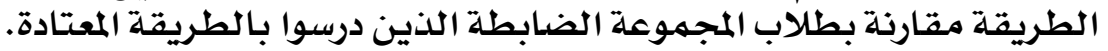

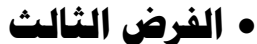

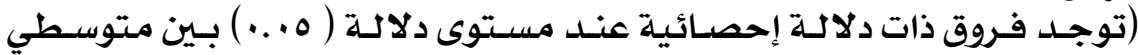

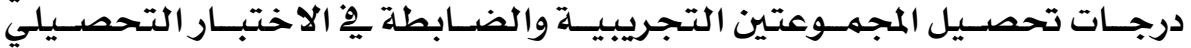

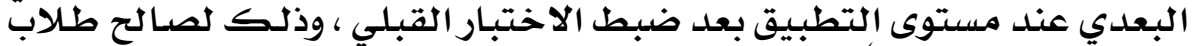

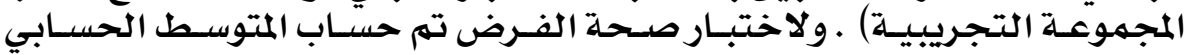

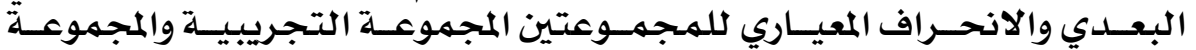

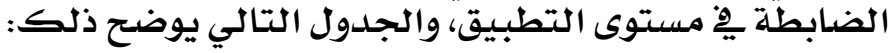

جدول (ه ) يوضح متوسطي الأداء البعدي للمجمومتين التجريبية والضابطة فِ مستوى التطبيق دوليق

\begin{tabular}{|c|c|c|c|}
\hline \multicolumn{2}{|c|}{ المجموعة الضابطة } & \multicolumn{2}{|c|}{ المجموعة التجريبية } \\
\hline الانحراف المعياري & المتوسط الحسابى & الانحراف المعياري & المتوسط الحسابي \\
\hline 3.01 & 5.11 & 2.23 & 6.12 \\
\hline
\end{tabular}

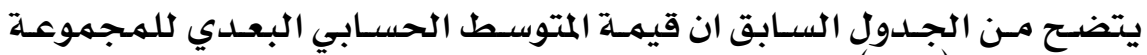

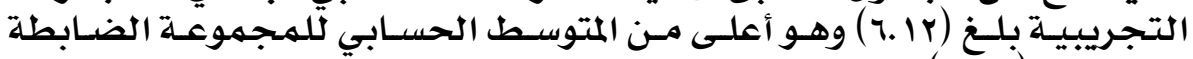
والذي بلنغ ( 0.11$)$

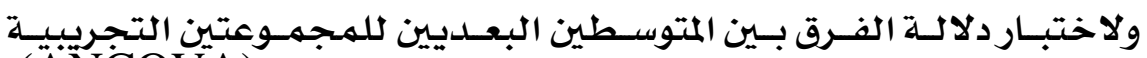

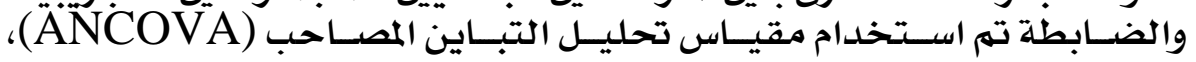

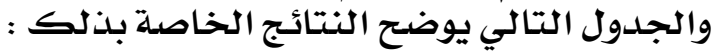

\section{$1 \wedge \Lambda$}




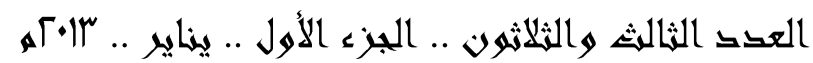

جدول (ף): يوضح تحليل التباين المصاحب لقياسات المجموعتين التجريبية والضابطة فِ مستوى

\begin{tabular}{|c|c|c|c|c|c|}
\hline \multicolumn{6}{|c|}{ التطبيق } \\
\hline الدلادلة & قيمـة "ف" & متوسطات & الحرجـة & ملمجموع & مصدر التباين \\
\hline 0.212 & 1.522 & 0.523 & 1 & 0.523 & القبلىير) المصاحب (الاختبار \\
\hline 0000 & $* 20.230$ & 7.01 & 1 & 7.01 & أعامل التجريبي ( بين \\
\hline & & 0.349 & 61 & 13.624 & الخطأ ( داخل المجموعات ) \\
\hline & & & 60 & 21.905 & المجموع المصحتح \\
\hline
\end{tabular}

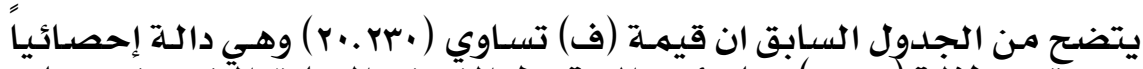

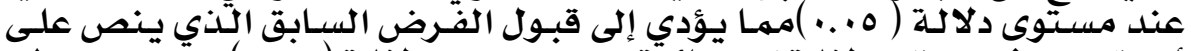

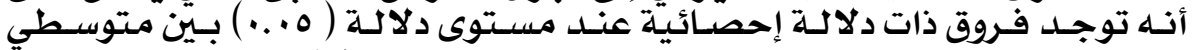

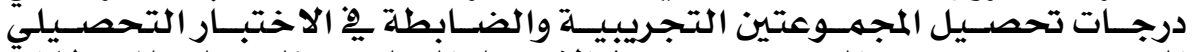

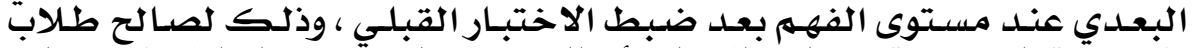

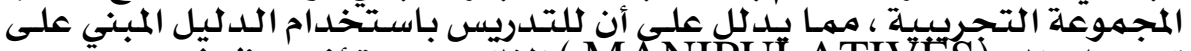

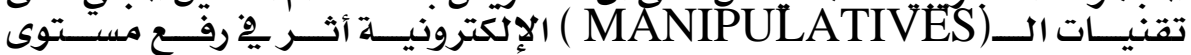

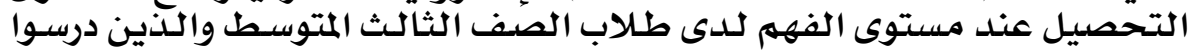
بهذه الطريقة مقارنة بطلاب المجميوعة الضمابطة الذئل الذين درسوا بالطريقة المعتادة.

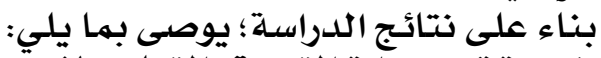

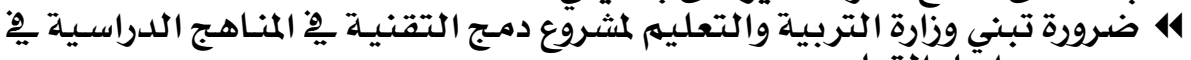

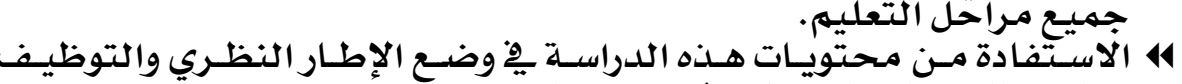

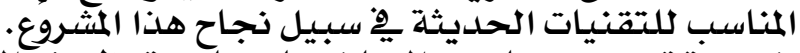

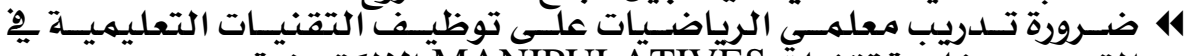

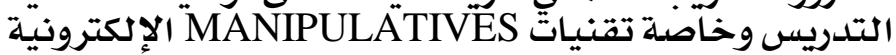

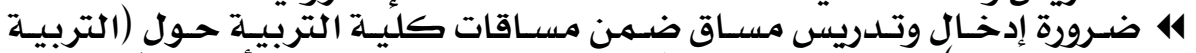

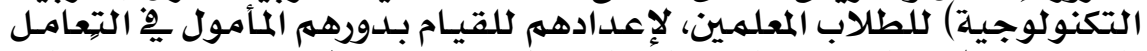

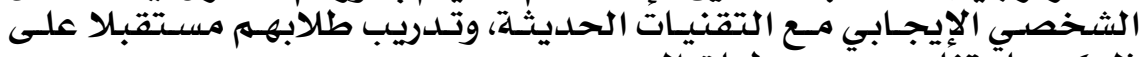

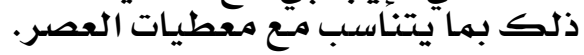

استكمالا لمجال الدهال الدراسـة الحالية يُقتَّرح القيام بالدراسـات التالية:

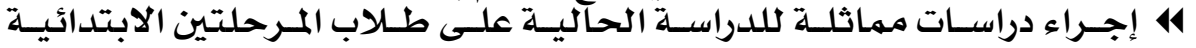
والثانوية.

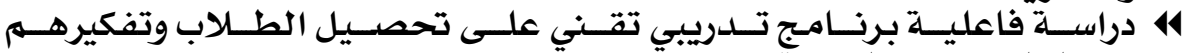
واتجاهاتهم نحواتهو التقنية. 414

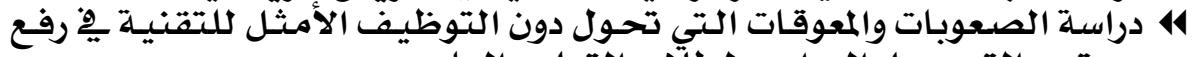

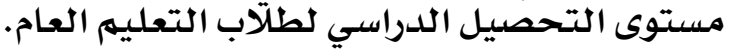

\section{$1 \wedge 9$}




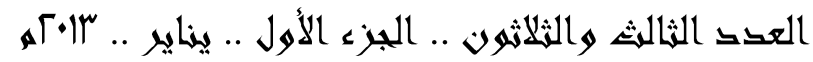

\section{• المــراجع والسمصادر:

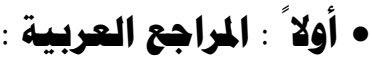

( ) أبو العباس، أحمد والعطروني، محمد : تدريس الرياضيات المعاصرة بالمرحلة الابتدائية.

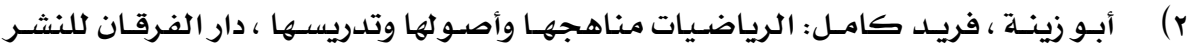

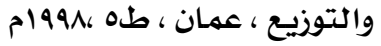

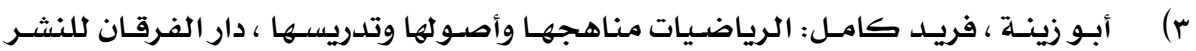

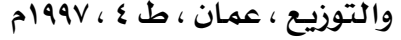

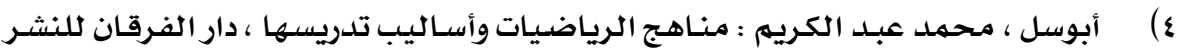

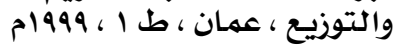

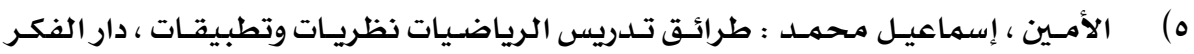

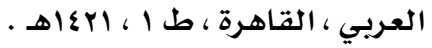

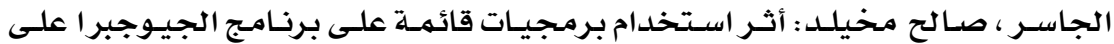

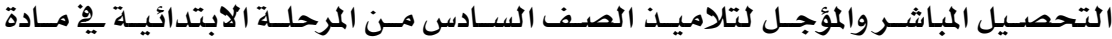

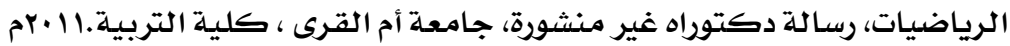

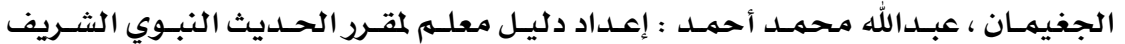

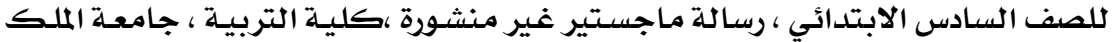

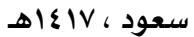

^) الحسن ، هشام وآخرون : تطور التفكير عند الطفل ، دار الفكر للنشـر والتوزيـع ، عمـان ، . 199.

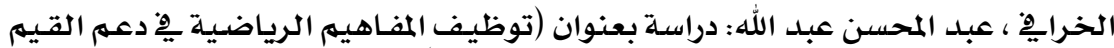

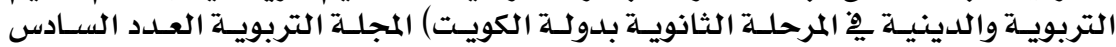

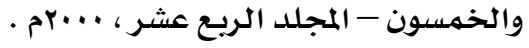

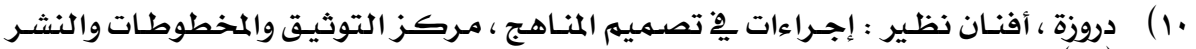

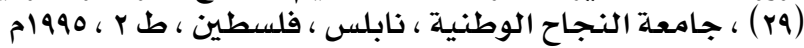

سالهم ، مهلدي محمود: الأهداف السلوكية ، مكتبـة العبيكان ، الرياض ، الطبعـة الثانيـة ه1ร19،

سلامـة، حسن علي : . طرائق تدريس الرياضيات بين النظريـة والتطبيق. القـاهرة، مصري: (Ir

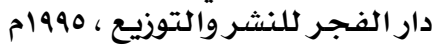

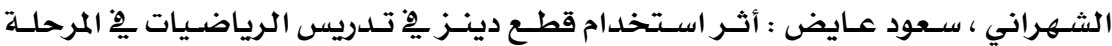
(ir

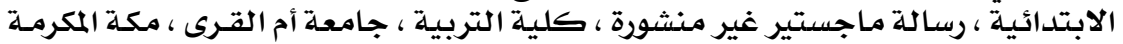
ها\&Yr،

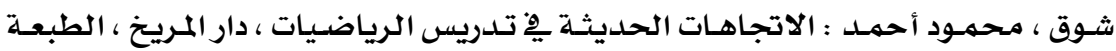
( I

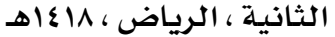
10) شوق ، محمود أحمد :بناء منهج للرياضـيات للصفوف الأول والثثاني والثالث الابتدائيـة هاء 


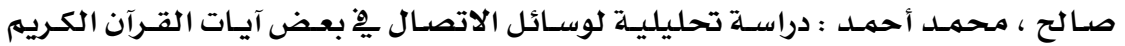

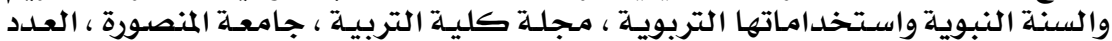

مام

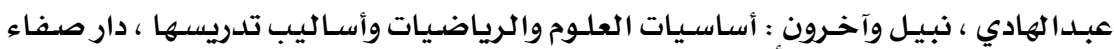

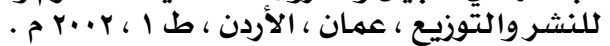

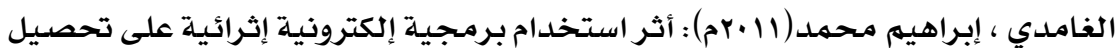

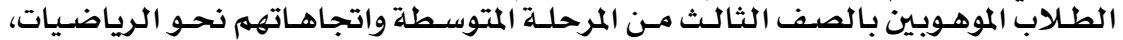

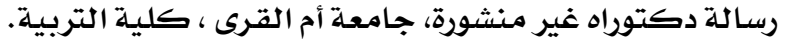

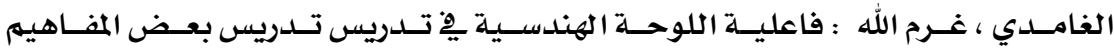

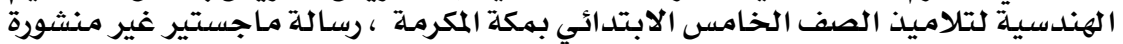

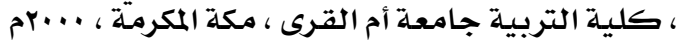

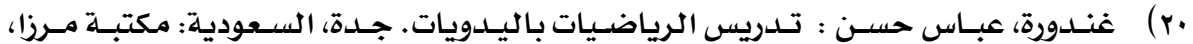
هاء

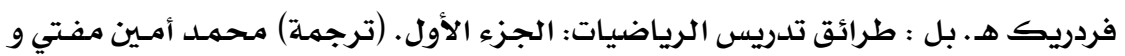

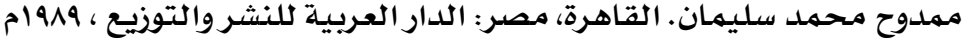

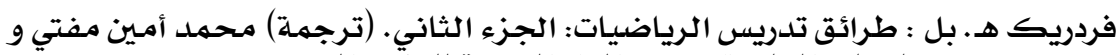

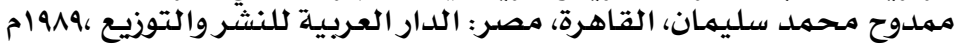

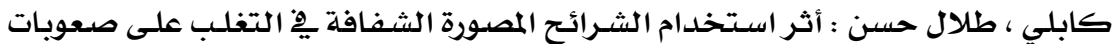

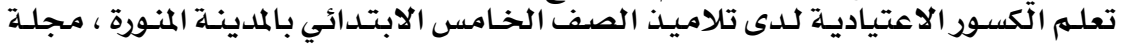

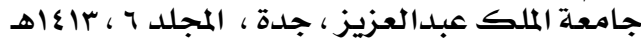

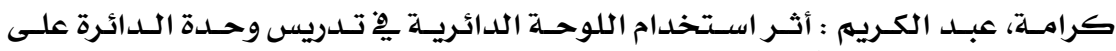

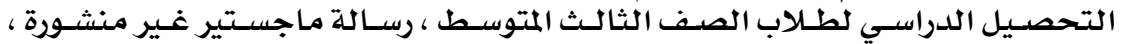

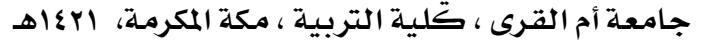

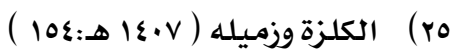

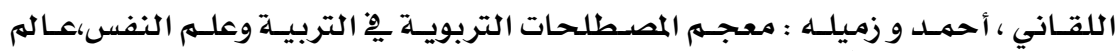
(ry

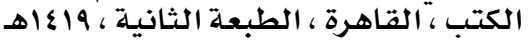

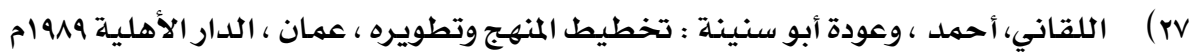

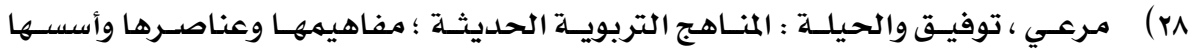

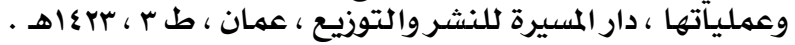

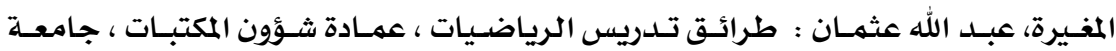

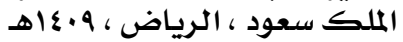

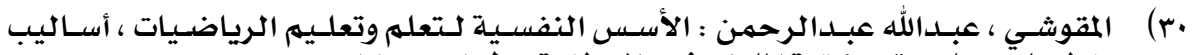

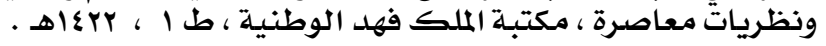

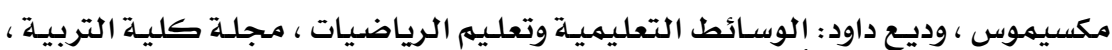

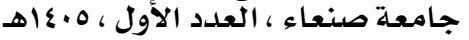

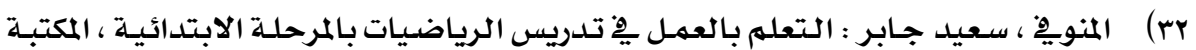

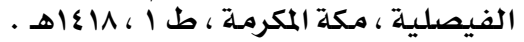




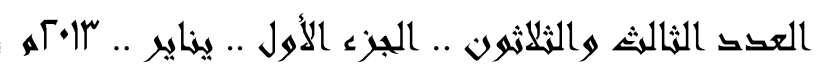

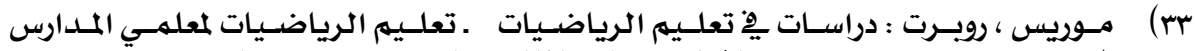

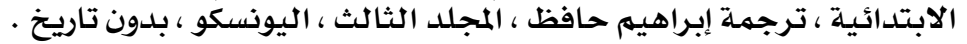

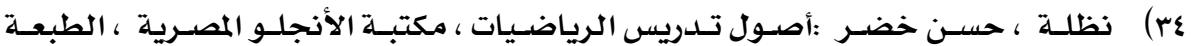

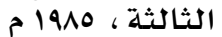

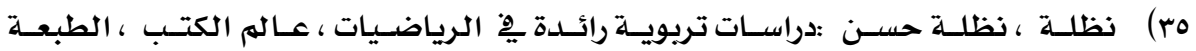

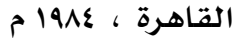

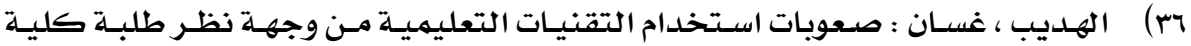

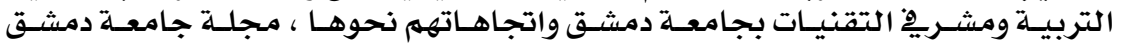

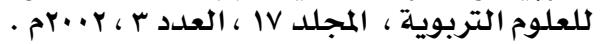

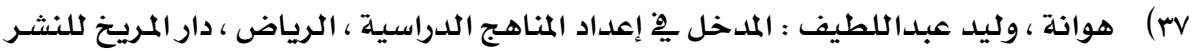

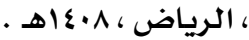

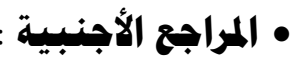

1) Buckley, B., (2000). Interactive multimedia and model-based learning in biology. International Journal of Science Education. 22(9), 895-935.

2) Clements D. H . other . improving Mathematics Teaching by uising Mainipulativis : An article published py JAMES w . H eddens Kent State University . Iric .

3) Clements, D.H., \& Battista, M.T. (1990). Constructive learning and teaching. The Arithmetic Teacher, 38, 34-35.

4) Cook, Carol Eileen (1995). The effect of microcomputer assisted instruction on the achievement scores of third grade math students. DAI. A34/03, p.942.

5) Walker , K. \& Zeidler, D (2003):"Students Understanding of the Nature of Science and their Reasoning on Socioscientific Issues: A Web-Based Learning Inquiry", ERIC, Document Reproduction Service No. ED474454 .

6) Watkins, G. (1999). Effects of cd rom instructions on achievement and attitudes. D. A. I. 571(4), October, 1446-A.

\section{潾潾潘潾潾}

